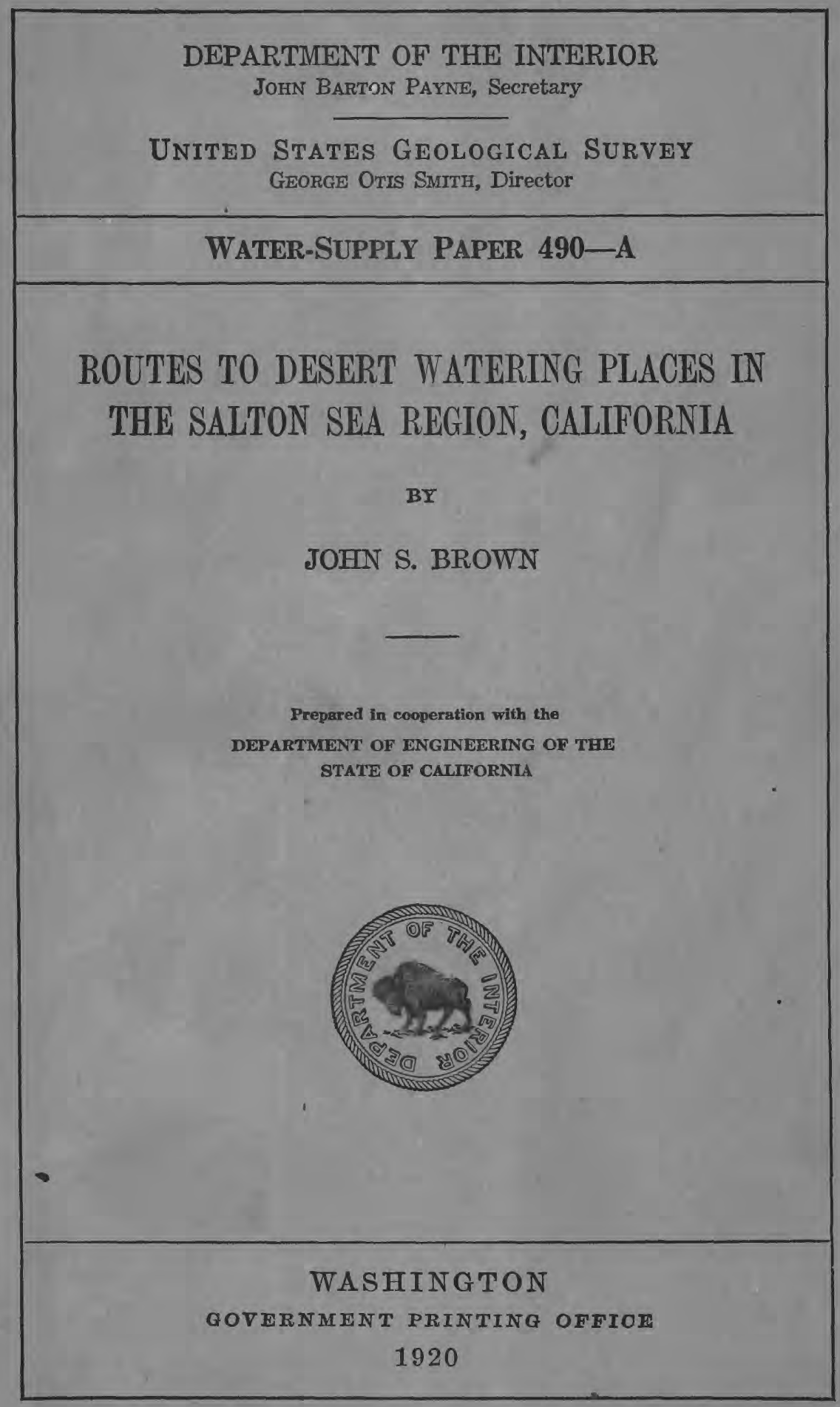




\section{DEPARTMENT OF THE INTERIOR}

- John Barton Payne, Secretary

\section{UNITEd States Geological SuRvey}

George Otis Smith, Director

\section{Water-Supply Paper 490-A}

\section{ROUTES TO DESERT WATERING PLACES IN THE SALTON SEA REGION, CALIFORNIA}

BY

JOHN S. BROWN

Prepared in cooperation with the

DEPARTMENT OF ENGINEERING OF THE STATE OF CALIFORNIA

WASHINGTON

GOVERNMENT PRINTING OFFICE

1920 



\section{CONTENTS.}

Preface, by O. F. Meinzer Page.

Introduction

Location of the region

Scope of the report

Methods of field work

Explanation of maps__-__- 6

Acknowledgments _-_. 7

Description of the region_._. 7

Physical features___- 7

Settlements._-_. 7

Roads_._-_-_-_-_._- 8

Means of travel_._- 8

Suggestions to travelers______- 8

General advice_______ 8

Teams, hay, and grain___- 9

Special suggestions to motorists

Provisions__._-_._-_._-_._- 11

Clothing and bedding 12

Fuel _-_._-___- 12

Water-_._. 12

Methods of carrying water

Kinds of watering places

Indications of water

Getting lost _-_._-_-_- 13

Main roads across the region

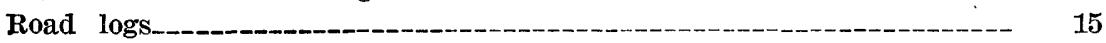

Los Angeles-Banning -

Banning-Coachella-Mecca _-_._- 15

Banning to Mecca_-_ 15

Mecca to Banning._- 16

Coachella-Brawley___-____-_ 18

Coachella to Brawley_-__-_-_._- 18

Mecca to Brawley

Brawley to Coachella____-_-_- 20

To Mecca from Brawley road_-__- 22

Brawley-Niland -_._-_-_-_-_- 22

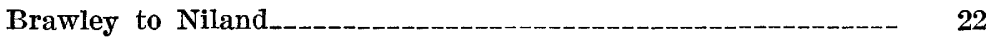

Niland to Brawley-_-_- 22

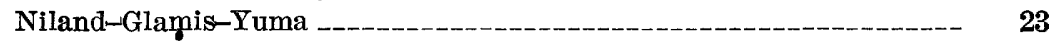

Niland to Yuma_-___-_-_- 23

Yuma to Niland______- 25

Brawley-El Centro__._._-_._. 26

Brawley to El Centro______ 26

El Centro to Brawley 
Road logs-Continued. Page.

San Diego-Jacumba______ 27

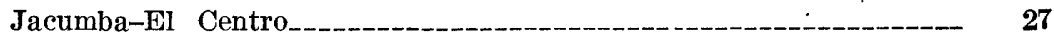

Jacumba to El Gentro__-___- 27

EI Centro to Jacumba_. 28

El Centro-Yuma______- 28

EI Centro to Yuma______ 28

Yuma to El Centro

Warner-Borego Valley-Brawley

Warner to Brawley

Warner to Brawley by way of cut-off or county road_____- 34

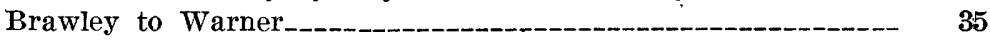

Brawley to Warner by way of cut-off or county road______- 38

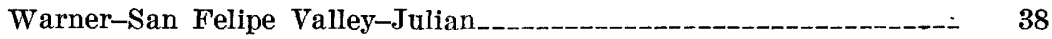

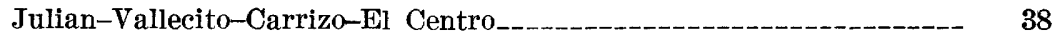

Julian to EI Centro___- 38

El Centro to Julian

Carrizo-Imperial _._-_._-_._- 43

Carrizo to Imperial______ 43

Imperial to Carrizo___-_._- 44

Dixieland to Yuha and Coyote Wells___._._. 45

Mecca-Blythe-Ehrenberg (main route) _..._-_._- 45

Mecca to Blythe

Blythe to Ehrenberg

Ehrenberg to Blythe_._.

Blythe to Mecca

McCoy 'Spring from Mecca-Blythe highway

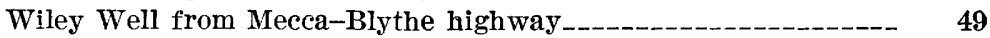

Corn Spring from Mecca-Blythe highway

Mill Camp roads__.__-_-_-_. 49

Boulder Well from Mecca-Blythe highway__-_._- 50

Mecca-Dos Palmas-Chuckwalla Well-Blythe__________________ $\quad \mathbf{5 0}$

Mecca to Blythe

Blythe to Mecca

Mecca to Niland, on east side of Salton Sea__________ 55

General outline._._.

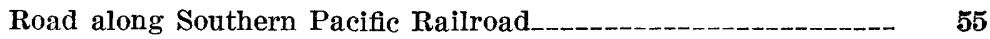

Road along power line

Road through Dos Palmas and Frink Spring

Niland to Gulliday Well______ 56

General outline-_- 56

Niland to Chocolate Mountains_. 56

Iris Pass______._- 56

Mecca-Blythe road crossing

Gulliday Well. 57

Surveyors Pass road____

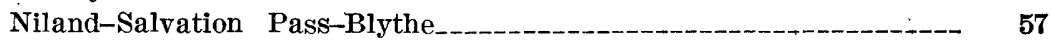

Blythe-Glamis route to Yuma and Imperial Valley_-_-_._._-_._-_ 58

Blythe to Glamis._. 58

Glamis to Blythe

Blythe-Yuma route by way of Tumco___ 61

General statement__. 61

Blythe to Yuma___

Yuma to Blythe 
Road logs-Continued.

Page.

Yuma to Picacho

Yuma to Laguna dam

Blythe-Blythe Junction

Blythe to Blythe Junction

Blythe Junction to Blythe..._. 65

Blythe to Blythe Intake

Blythe Intake to Parker.

McCoy Spring, Adams Well, Chandler Well, and McCoy Tanks, from Blythe and Blythe Junction.

66

Mineral Switch to McCoy Spring.

66

Mineral Switch to McCoy Tanks________________ 67

Mineral Switch to Adams Well_____ 67

Old route from McCoy Tanks to Patterson and Graham wells_______ $\quad 67$

Mecca to Cottonwood Spring, Iron Chief mine, Dale, Eldorado mine,

Twenty-nine Palms, Pinyon Well, and Indio

Mecca to Dale by way of Cottonwood Spring-_____-_-_-_-_ 68

Iron Chief mine________ 69

Road west from Cottonwood Spring

Cottonwood Spring to Eldorado mine and Pinyon Well_________- 69

Pinyon Well to Indio

Eldorado mine to Twenty-nine Palms by way of White Tank___- , 71

Banning-Dale

Banning to Quail Spring, Keys Ranch, Pinyon Well, and Eldorado mine.

Whitewater to Palm Springs station

Palm Springs to Palm Canyon

Watering places

\section{ILLUSTRATIONS.}

Plate I. Map of the arid region of the United States showing areas covered by guides to watering places and other maps and water-supply papers of the United States Geological Survey --

II. $A$, First desert watering place signpost erected by the United States Geological Survey; $B$, Typical bad road traversed in desert watering place survey

III. Typical desert watering place signpost erected by the United States Geological Survey

IV. $A$, View in Mohave Desert, Calif.; $B$, Near view of the hidden spring in the Mohave Desert; $C$, United States Geological Survey signpost directing to spring

v. Index map of Salton Sea region, Calif

VI. Relief map showing desert watering places in the western half of the Salton Sea region, Calif In pocket.

VII. Relief map showing desert watering places in the eastern half of the Salton Sea region, Calif In pocket.

Frgure 1. Sketch map of vicinity of Blythe Junction, Calif

2. Sketch map showing roads in vicinity of Dale, Twenty-nine Palms, and Pinyon Well, Calif 



\section{ROUTES TO DESERT WATERING PLACES IN CALIFORNIA AND ARIZONA.}

PREFACE.

By O. E. Meinzer.

The desert region of the United States forms a great triangle whose base, 800 miles long, is the Mexican border from the Peninsular Mountains, in southern California, to the mouth of Pecos River, in Texas, and whose apex is in north-central Oregon. The west side of this huge desert triangle is the mountain wall formed by the Peninsular Mountains, the Sierra Nevada, axd the Cascade Range; the east or northeast side is a less definite line extending from northcentral Oregon through Salt Lake City and Santa Fe to the mouth of Pecos River. (See Pl. I.) It covers about 500,000 square miles, or very nearly one-sixth of the area of the United States.

This region is by no means devoid of natural resources or human activity. It contains prosperous cities, fertile agricultural districts, forest-clad mountains, a large aggregate number of watering places, many rich mines, and an unknown wealth of mineral deposits. But the localities that have water supplies are widely separated oases in a vast expanse of silent, changeless, unproductive desert, whose most impressive feature is its great distances and whose chief evidences of human occupation are the long, long roads that lead from one watering place to another.

In the future existing oases will be enlarged, many new ones will be created, and the mineral and agricultural product of the region will be greatly increased. But in spite of all that man can do this large region will remain essentially a desert.

Travelers in this region must depend for their existence on the desert water holes (springs, wells, or natural tanks), many of which are separated from one another by a hard day's journey with team and wagon. For most of the region the water holes have never been accurately mapped or described, no systematic provision has been made for maintaining them, and the roads leading to them have not been marked with substantial and reliable signs. Hence travel in the remote parts of the region has been a precarious and sometimes a dangerous undertaking. 
The need of a systematic program for making the desert safe and accessible by mapping, marking, and improving its watering places has long been appreciated by public-spirited men who know its conditions. It has also been recognized that because of the great extent of the region and because most of it still belongs to the public domain the Federal Government can best do this work. For nearly 20 years Mr. George W. Parsons, of Los Angeles, has ardently advocated such a program.

Data on desert watering places were compiled some years ago by Gilbert E. Bailey, who was obliged to traverse repeatedly many of the main desert roads and trails, and these data were made available by him for use in a guide to watering places throughout a large desert area in California and Nevada published by the United States Geological Survey in 1909. ${ }^{1}$

Considerable other work has been done by the United States Greological Survey in making maps of parts of the region and in publishing data on its water resources. (See Pl. I.) Signposts have been erected by States, counties, automobile associations, and other agencies, the Automobile Club of Southern California having been especially active in the southwestern part of the region. However, definite and precise information in regard to watering places, except those along the main roads, has not been available for most of the region, and most travelers in the desert have been obliged to grope their way through it by means of hearsay information.

A systematic program for the survey, marking, and protection of desert watering places was authorized by an act of Congress approved August 21, 1916, which reads as follows:

Be it enacted by the Senate and House of Representatives of the United States of America in Congress assembled, That the Secretary of the Interior be, and he is hereby, authorized and empowered, in his discretion, in so far as the authorization made herein will permit, to discover, develop, protect, and render more accessible for the benefit of the general public springs, streams, and water holes on arid public lands of the United States; and in connection therewith to erect and maintain suitable and durable monuments and signboards at proper places and intervals along and near the accustomed lines of travel and over the general area of said desert lands, containing information and directions as to the location and nature of said springs, streams, and water holes, to the end that the same may be more readily traced and found by persons in search or need thereof; also to provide convenient and ready means, apparatus, and appliances by which water may be brought to the earth's surface at said water holes for the use of such persons; also to prepare and distribute suitable maps, reports, and general information relating to said springs, streams, and water holes and their specific location with reference to lines of travel.

An appropriation of $\$ 10,000$ became available for this purpose July 1, 1917. With this appropriation, supplemented with some

1 Mendenhall, W. C., Some desert watering places in southeastern California and southwestern Nevada: U. S. Geol. Survey Water-Supply Paper 224, 1909. 


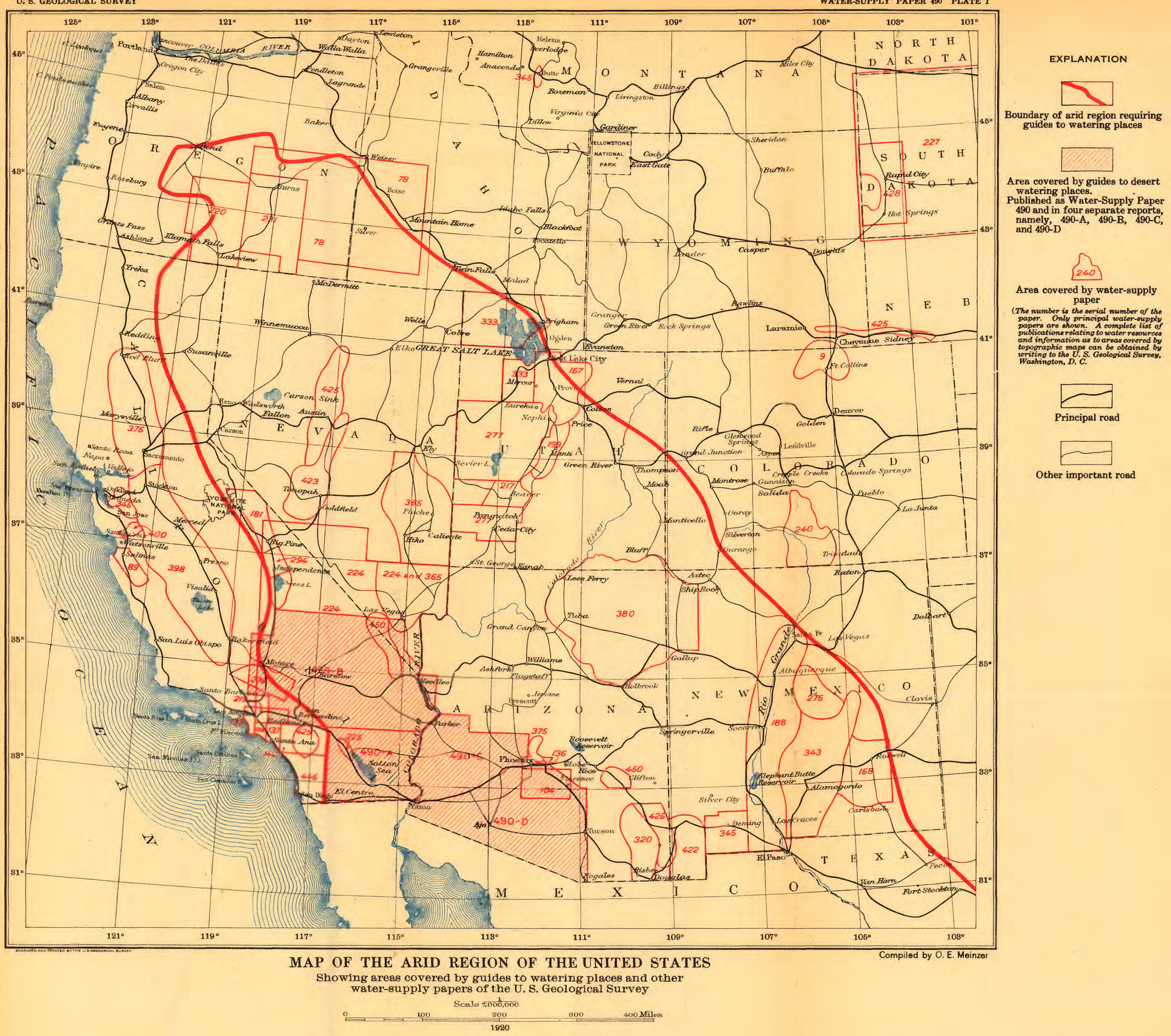



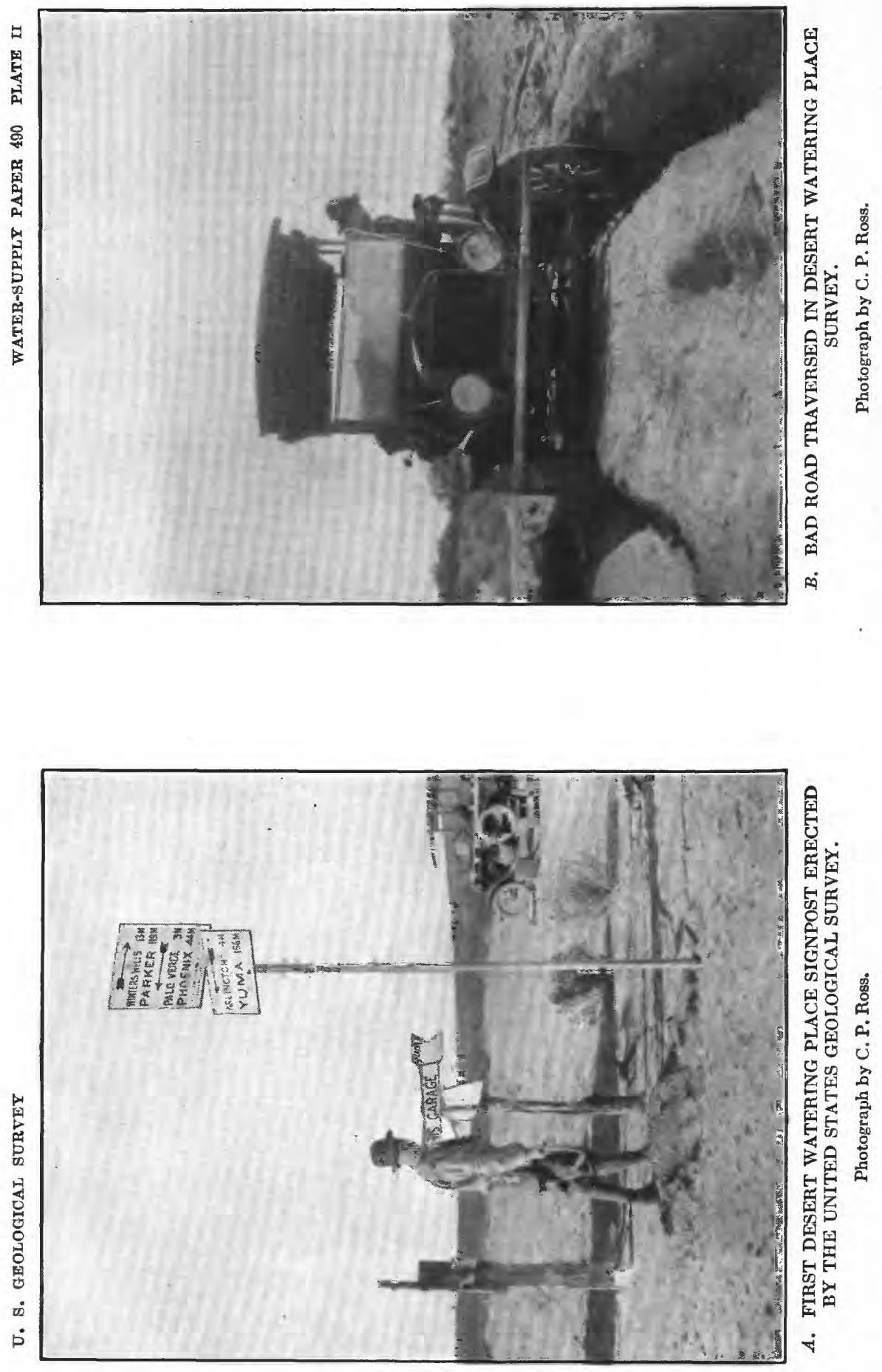


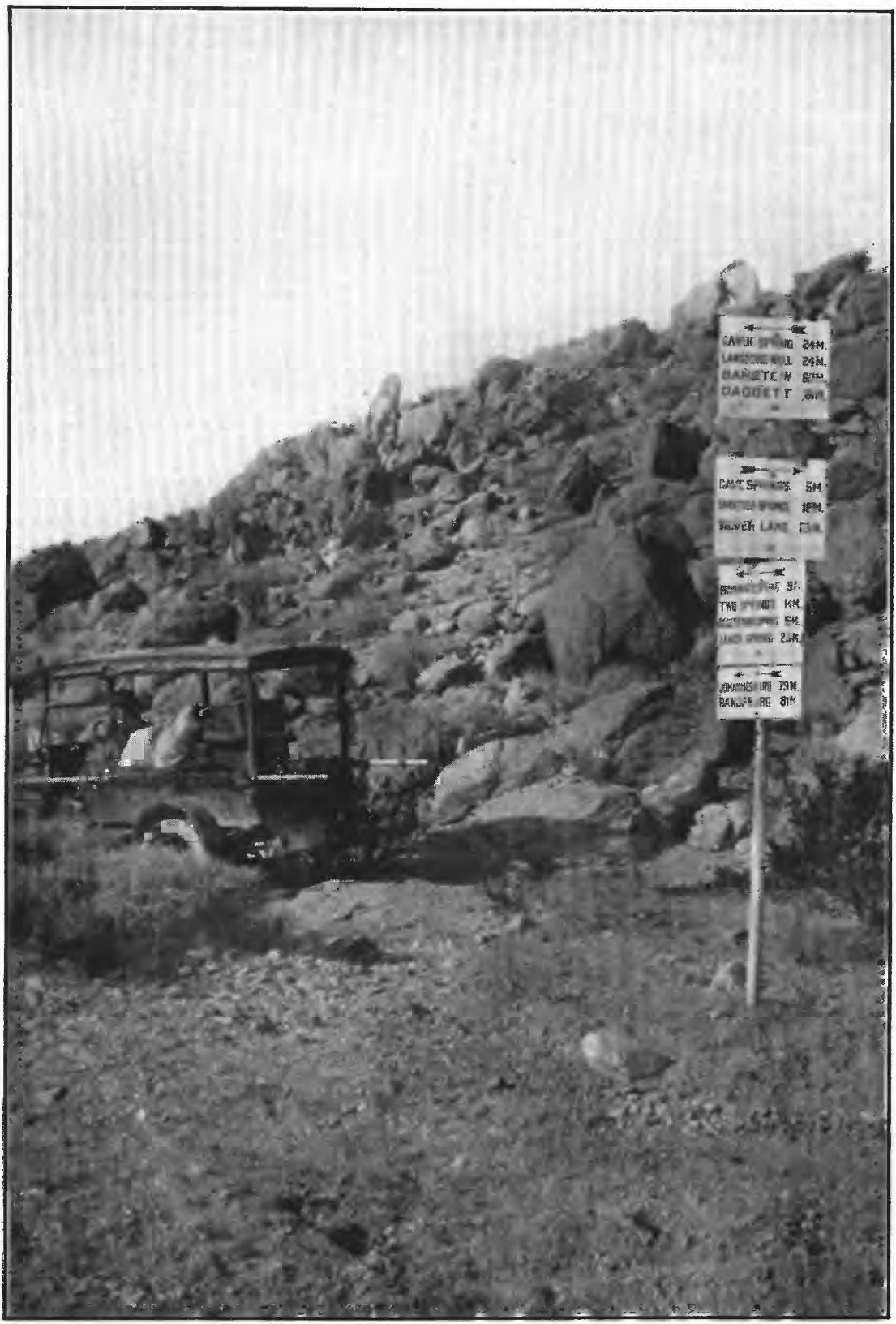

TYPICAL DESERT WATERING PLACE SIGNPOST ERECTED BY THE UNITED STATES GEOLOGICAL SURVEY.

Photograph by D. G. Thompson. 
other funds that could be used for the purpose, a survey was made in 1917 and 1918 of the driest, hottest, and least explored part of the desert region, comprising 60,000 square miles in southeastern California and southwestern Arizona. (See Pl. I.) It includes the southern part of Death Valley and the region between this valley and the Mexican border in California, and the region west of Tucson and Phoenix and south of Wickenburg and Parker in Arizona. The field work was done by four parties, each consisting of one geologist and one nontechnical assistant and each provided with an automobile and light camping equipment. The mapping was done with the plane table, on a scale of 1:125,000. Most of the watering places in the region were examined; about 160 samples of water were collected and shipped to the water-resources laboratory of the United States Geological Survey for analysis; and a general exploration was made of the region to determine its geography and geology and its ground-water conditions.

Signs directing travelers to water were erected at 167 localities in California and 138 in Arizona, (See Pls. II, $A$, and III.) The signposts are of galvanized iron, 1.9 inches in outside diameter and 12 feet long. Each post is anchored to the ground with two redwood blocks. The signs are 18-gage steel, galvanized, are white, with dark-blue letters, and are substantially bolted to the posts. They are of two sizes, 18 by 20 inches and 9 by 20 inches. Most of the larger signs, 470 of which were erected, give the names, distances, and directions to four watering places; most of the smaller signs, 165 of which were erected, give the names, distances, and directions to two watering places. Through the courtesy of the Board of Supervisors of San Bernardino County, Calif., signs were placed on 26 iron posts previously erected by the county.

The area covered is the part of the desert region where such work was most needed, not only because, on the whole, it has remained the least explored, but also because it is the hottest and most arid area and the one having the worst roads. (See Pl. II, B.) The work was, however, undertaken as a part of a larger plan, which contemplatesto the extent that funds are available-a similar survey and erection of signposts for the entire arid region, as outlined on Plate I. To make the work permanéntly effective it will be necessary from timé to time to revise the maps and guides and to repair and supplement the signposts. The Federal Government is also under obligation to maintain the desert watering places that have been withdrawn from entry and are held as public water reserves.

Soon after the field work was completed three of the four geologists who made the survey entered the Army and the other one was assigned to work on water supplies for military establishments. 
Consequently the preparation of the maps and guides to desert watering places had to be postponed until after the war. Reports are now being prepared which will give detailed information about the watering places in the region and will contain more comprehensive and accurate descriptions of its geography, geology, and hydrology than have hitherto been published. The four abbreviated guides comprising the present series (Water-Supply Paper 490) are published in advance of the complete reports for the use of those who do not need the more general information which the complete reports contain. These abbreviated guides consist essentially of the maps, the road logs (which constitute concise guides to watering places), and very brief descriptions of the watering places. 


\title{
ROUTES TO DESERT WATERING PLACES IN THE SALTON SEA REGION, CALIFORNIA.
}

\author{
By JoHN S. Brown.
}

\section{INTRODUCTION.}

\section{IOCATION OF THE REGION.}

The region covered by this guide occupies the southeast corner of California and constitutes roughly a square 100 miles in length and breadth, or about 10,000 square miles in area. On the south its border is the boundary between the United States and Mexico, and on the east Colorado River, which separates California and Arizona. The northern and western bqundaries have been arbitrarily set at the 34th parallel and the meridian of $116^{\circ} 40^{\prime}$. The limits thus set include Imperial County and the most arid parts of Riverside and San Diego counties. (See Pl. V, p. 14.)

\section{SCOPE OF THE REPORT.}

In addition to maps showing the roads and watering places, the information in the guide consists of road logs and brief, descriptions of watering places. For the convenience of travelers from any direction the logs of all the principal roads are given in two directions. Information and sketch maps are included-for certain roads extending somewhat beyond the northern boundary of the region as defined above, in order to connect the routes of this region with important watering places beyond its limits. On the other hand, a considerable part of the western edge of the region is high, wellwatered mountainous territory, and routes in it are given only for certain irregular westward extensions of the desert.

\section{METHODS OF FIELD WORK.}

Field work for this report was carried on during the winter of 1917-18. The party consisted of the writer and a nontechnical assistant and was equipped with a Ford automobile and a light camping outfit. Only such stops were made at towns or settlements 
as were necessary for procuring supplies or information, most of the time being spent in the uninhabited and least explored areas. A plane-table map was made along all routes that were traveled, distances being measured by an accurately registering odometer, and triangulation carried along on mountain peaks or other prominent landmarks. Careful search and inquiry were made for watering places, and every one that was accessible was visited and mapped as far as time permitted. Approximate locations and descriptions of some others were obtained from various sources. Because the territory is so large, it was impossible to locate every watering place, but it is believed that very few of those which are ordinarily utilized by the public have escaped observation. In such thinly settled regions as this there are always places, known only to prospectors and chance wayfarers, where water is obtainable at certain seasons but which are too little known or too remotely situated to be of general importance.

\section{EXPLANATION OF MAPS.}

As a result of this work it has been possible to construct maps of the region covered which give the locations of the physical features, roads, watering places, and settlements with a degree of accuracy much greater than any previously published. Free use has been made of material from other sources, particularly in those areas not reached during the investigation. The topographic maps published by the United States Geological Survey cover parts of the region on the western border, around Salton Basin, and in the southeast corner. An accurate survey of Colorado River has also been made by the Geological Survey. The boundary line between the United States and Mexico has been carefully surveyed by a joint boundary commission. Maps published by the United States Land Office have furnished some valuable information, and private maps and surveys by irrigation companies have been useful in some localities. The surface features are shown by relief shading, executed by J. H. Renshawe, of the United States Geological Survey, based on all available data. This method furnishes a pictorial representation of mountain ranges combined with a scheme of shading to. indicate relative elevations. Thus the lightest-colored areas are the highest, the darkest ones the lowest. With a little care, if a few elevations are known, it is possible to judge pretty accurately the height of any locality.

Names corresponding to the title under which roads are described in the text appear on the map along the roads and afford a ready means of referring to the road logs. Obviously these names have no geographic significance and merely indicate the units into which road logs are divided. 
Township lines have been shown on the maps wherever land surveys exist, but the original surveys, made about 1856 , have been found very faulty and are replaced by resurveys at some places and not at others. Accordingly section locations, particularly in the eastern part of the territory, will often be found rather unreliable. An effort has been made to keep the maps as free from unnecessary detail as possible, particularly in settled areas, where no attempt is made to indicate more than the principal roads and towns.

\section{ACKNOWLEDGMENTS}

The author is indebted to many persons for assistance in the field and office. Particular credit is due to Mr. B. W. Broderson and Mr. W. C. Vaubel, both of Los Angeles, for their very efficient help as assistants in the field. The Automobile Club of Southern California cooperated freely with information and assistance. Business men, well drillers, miners, prospectors, and farmers of the region gave invaluable information and aid for which it is impossible to thank them all individually but which is none the less appreciated.

\section{DESCRIPTION OF THE REGION.}

\section{PHYSICAL FEATURES.}

Within this region there are wide variations of physical features within short distances. From lofty mountain regions, with forests of large trees, heavy winter snows, and an -annual precipitation of 30 inches or more on the west, there is a swift transition eastward to low desert ranges and valleys, nearly devoid of vegetation, where summer temperature prevails the year around and where there may be entire years practically without rain. As a whole this is the hottest and driest part of the United States.

The desert consists mainly of broad, nearly level areas with sandy or gravelly soil, separated by barren mountain ranges whose sides are commonly chocolate-colored and are deeply furrowed by dry canyons. The low flats usually constitute units to which the name valley is applied, such as Coachella Valley and Imperial Valley. They are generally covered with at least a scant growth of bushes or shrubs which are adapted to life under the prevailing conditions of heat and drought.

\section{SETTLEMENTS.}

Some of these valleys where a supply of water can be obtained have been developed by irrigation to a remarkable degree of productivity, and large settlements exist at these isolated places. Coachella Valley, Palo Verde Valley, Yuma Valley, and Imperial Valley are the principal centers of agricultural development. 
ROADS.

The transcontinental line of the Southern Pacific Railroad, completed in 1879, crosses the region from southeast to northwest, and several branch lines from various places have been built in recent years to serve the irrigated areas. Consequently the centers of agricultural development are provided with good transportation facilities and constitute important supply points. Within the settled areas good roads are common. Long stretches of pavement are found on some of the chief highways. But practically all the roads through the undeveloped region are entirely unimproved. They are not laid out along definite lines, but follow in a general way the easiest natural routes available, crossing valleys and threading mountain passes, and avoiding as much sand and as many hills as possible. The result is that a desert road usually consists of two wheeltracks, and if these become bad a new one is made somewhere in the vicinity.

Mining is practically the only business which attracts travel away from the main roads. Development at any place is subject to many. uncertainties, and camps appear and disappear rapidly. Roads are made and fall into disuse. Where wagon or automobile roads are impracticable, pack animals are used and burro trails result.

\section{MEANS OF TRAVEL.}

All the ordinary means of travel are used in this region. While teams and wagons are still used, they have been replaced to a great extent in recent years by automobiles. Trucks are coming into use on a commercial scale for freighting from mines in places away from the railways. The burro is still the faithful friend of the prospector and the horse of the "cow man," but automobiles are also much used by prospectors, for with them it is usually possible to get somewhere near even the most inaccessible territory. Foot travel is uncommon, although transient laborers often tramp from one valley to another, particularly during the period of seasonal oecupations such as cotton picking.

\section{SUGGESTIONS TO TRAVELERS.}

\section{GENERAI ADVICE.}

To one taking the proper precautions the desert is much less to be dreaded than the average stranger imagines. Only in midsummer heat is it really a dangerous place. Nevertheless, a few short trips without mishap should not lead one to a careless contempt for its very real perils. No matter in what sort of vehicle or for what length of time it is planned to enter the desert, adequate provision for pos- 
sible misfortunes should be made. Probably more fatalities and hardships result at present from the failure of automobilists to know the road or to take a little food or an extra supply of water than from any other cause. Of course, with a good automobile and good luck one can travel across this region in a day; but an accident in the midst of a lonely waste may leave a party stranded without help for days, or until it is possible to walk to civilization.

It is necessary, first, to learn definitely about the road. Procure the best maps available. The one in this guidebook is believed to be the best general map of the region yet published, but for numerous byways and burro trails it is not accurate in detail. Moreover, desert roads are frequently changed with the exigencies of travel, and what is a plain road one day may be obliterated by a sandstorm and abandoned the next. Still the main routes are controlled by surface features and remain much the same. Numerous private maps of local districts are valuable, and the automobile clubs and touring bureaus supply good maps of the chief automobile roads, which, however, are not drawn accurately to scale.

Inquiries should be made of local garage men and hotel keepers about the roads and watering places. Garage men usually have the latest information as to the condition of automobile roads. Inquiry about watering places and their condition at the time should be made, as a broken pump may render a good well entirely useless for a water supply.

Some food should be taken even for an automobile trip of only a few hours. A surplus of water over probable needs of men and automobiles should be provided. Oil and gasoline more than enough for probable needs should be taken, and it should be remembered that desert roads may require twice as much per mile as pavement. Supplies for horses should be ample for all possible contingencies.

\section{TEAIMS, HAY, AND GRAIN.}

The following excellent suggestions to desert travelers are taken from a paper by Mendenhall ${ }^{1}$ and are especially pertinent for persons traveling with teams:

Where teams are used animals accustomed to the desert should be procured if possible, for horses or mules that are unused to desert condition fret on the sandy roads, and rapidly weaken from drinking the saline waters. They are also in danger of pneumonia from the cold of the winter nights and the wide extremes of temperature. During winter journeys blankets should be provided to protect the animals at night.

Travel in the desert far from the railroads and from food supplies is, of course, more expensive than in other regions. A party leaving a supply station

\footnotetext{
1 Mendenhall, W. C., Some desert watering places in southeastern California and southwestern Nevada: U. S. Geol. Survey Water-Supply Paper 224, p. 21, 1909.
} 
to go 100 miles or more into an uninhabited part of the desert must take along everything needed, even to the most minute detail. This means that if the trip is to last for two weeks enough hay and grain for each animal and enough provisions to last each man that length of time must be taken. For four horses, drawing a wagon that carries four persons and bedding, provisions, and tools. another team of four horses must also be taken to haul sufficient hay and grain to feed the eight horses for two weeks. There are but few places in the desert, away from the railroads, where grain or hay of any kind can be procured. As the teams are rarely able to travel faster than a walk, heavy horses that are good walkers should be selected. The tires should be as wide as can be procured. Desirable widths of tires for freight wagons are 6 to 9 inches; for light wagons 3 inches. *** For packing trips experienced prospectors select burros on account of their endurance of heat and thirst, their foraging abilities, and the slight amount of care they require. They are slow and too light to carry heavy packs, so that on expeditions where speed is essential, or heavy freight is to be moved and feed is available, horses or mules are to be preferred.

\section{SPECIAL SUGGESTIONS TO MOTORISTS.}

More people travel the desert now in automobiles than in any other way, although horses are not unknown and even foot travelers are sometimes seen. Low-geared trucks with large tires have an advantage in freighting or traveling very sandy roads. With an experienced desert driver the average car can travel almost any road that is passable for wagons. Without careful driving it may fail to get anywhere on a comparatively good road. Automobile parties should always carry a supply of spare tires and tubes. A vulcanizing outfit for making patches is especially desirable. A tire gage is very useful, and an air pump and a jack are necessary.

Sand is the worst obstacle in this part of the desert. Fortunately it is less prevalent than popular fancy imagines. The average road consists of a pair of wheel ruts; and in sandy places it is essential to stay in these ruts. Leave them only to pass another vehicle and then keep two wheels of the car in a rut if the sand is bad. Parties attempting to pass on a sandy road can usually do so by helping push the autos if other means fail. Wheel ruts, if fresh, are easily traversed even in deep sand, but old ruts or wagon tracks make very difficult traveling for automobiles. On such roads if a car gets stuck it is often possible to back up and by getting a fresh start in one"s own tracks break the road ahead through bad sand. A shovel is sometimes useful in short stretches for cleaning out covered ruts.

It is common practice in case of trouble in sand to deflate the tires. This gives the tire a greater bearing surface by allowing it to flatten out and increases the effectiveness of a car's gearing by reducing the diameter of the wheel. There is danger of rim cutting by having the tires too soft; so that no more air should be allowed to escape than is absolutely necessary. No fixed rule is known, but for Ford cars a pressure of 35 or even 30 pounds was found safe and 
always gave good results. Tires are not damaged by running "soft" in sand, but they should be immediately pumped up when hard ground is reached, or they will suffer rim cuts, stone bruises, or blow-outs: The tire gage is a necessity for judging the safe reduction of air pressure.

One great trouble in soft sand is that the wheels lose traction and spin, digging down and down into the sand. This is frequently brought about by attempting to start too suddenly. On the other hand going too slowly when moving induces the wheels to spin. After a wheel has "dug in" it has to be "dug out" with a shovel, jacked up, and the hole surfaced with brush, canvas, or stones to give a bearing. Very effective use can be made of two strips of heavy canvas, say 30 feet long and 18 inches wide, for such difficulties. The strips must be thrust under the rear wheel, then laid lengthwise ahead in the ruts, and it is necessary to lift the front wheels and set them on the canvas to hold it down while the rear wheels pull. Otherwise the canvas is chewed up and "spit" out in the rear by the spinning wheels. Canvas solved the trouble of the worst sand for the Survey party without much recourse to brush or shoveling. Progress is slow, but nearly any bad place may be crossed in this manner. The use of canvas for occasional trips on welltraveled roads is seldom necessary. Most travelers, instead of using canvas, fill the ruts with broken twigs, brush, stones, or anything else available when they get stuck, but unfortunately the brush is usually thinnest where the sand is thickest. There are various devices on the market for pulling out automobiles which get stuck, and one of these may be a valuable part of the equipment. On some roads in this region there are steep hills and sandy grades which automobiles can not ascend but which they can descend with ease. Such roads can be used only in one direction. To reach certain places it is necessary to choose circuitous routes in order to obtain feasible grades, and it may be necessary to follow a different route on the return trip from that taken in approaching.

\section{PROVISIONS.}

In the larger agricultural settlements in this region there áre towns which have hotels and restaurants and at which food, clothing, and mechanical equipment can be purchased. Persons planning to take trips of a day's duration or longer should take plenty of food. This will necessarily be in condensed form, chiefly canned goods and staples such as flour, sugar, coffee, and bacon. For short trips it was found very easy to carry fresh bread in paper seals, especially by using a tight can for a container. Crackers can be used for $157138^{\circ}-20-2$ 
longer journeys or bread can be made in camp. Butter in tight containers will keep for some time in winter. Cans with tightly fitting lids are desirable containers for such things as flour, coffee, etc. As much of vegetables, fruit, and canned milk should be taken as space will permit, because these things add variety to the rather scanty list of staples. Above all do not forget essential things which will be unobtainable in camp.

\section{CĹOTHING AND BEDDING.}

Persons camping in this region should remember that the nights are cool. Warm blankets and plenty of bedding are essential to comfort and to health. Bedding is usually made into a roll for the day, and a large sheet of canvas is convenient to protect it by day or night. There are no particular fashions or inherent necessities in clothing for the desert and one may choose here practically as he would anywhere else of the standard kinds of goods, remembering, as with bedding, that something extra may be needed for warmth at night.

\section{FUEL.}

Fuel can be found at most places in this region, though it may be necessary sometimes to camp at a completely barren spot. Dead wood decays very slowly in this climate and is abundant at most places where small brush grows freely. Roots or branches burn readily with great heat. Most of the desert plants bear thorns to some extent and heavy gloves are useful protection in gathering firewood. An ax or hatchet may be used but is rarely necessary. Fuel is often stripped away in the vicinity of water holes, so that it may be necessary to go several hundred feet away from these common camping grounds to get a good supply.

Some kind of camp light is necessary, ordinary kerosene lanterns being most used. Carbide or electric lamps are sometimes satisfactory substitutes.

\section{WATER.}

\section{METHODS OF CARRYING WATER.}

The most serious problem in desert travel is to obtain enough good water for drinking and camp uses and for teams or automobiles. It is necessary to have canteens, kegs, or water bags of sufficient capacity for all needs. Even tourists who do not plan to stop at all should carry a few canteens of water. Good canteens can be purchased at stores in all the towns. Water bags are excellent for keeping drinking water cool but waste water by evaporation. For cooking, 5-gallon kegs or cans are satisfactory containers. A day's supply is usually sufficient to carry, as there are very few places 


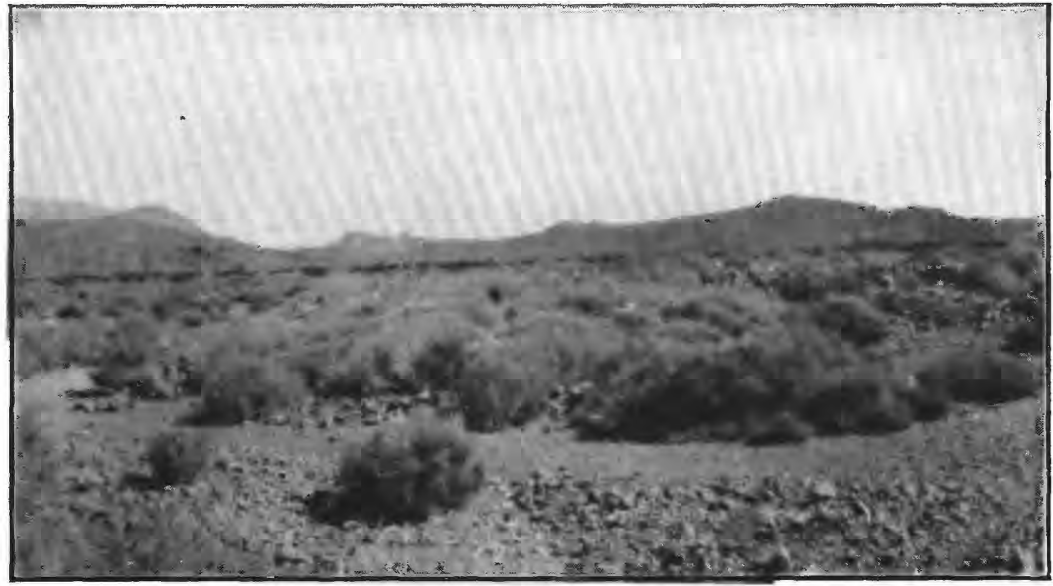

A. VIEW IN MOHAVE DESERT, CALIF.

The only water within 10 miles is a spring hidden under brush in this view.

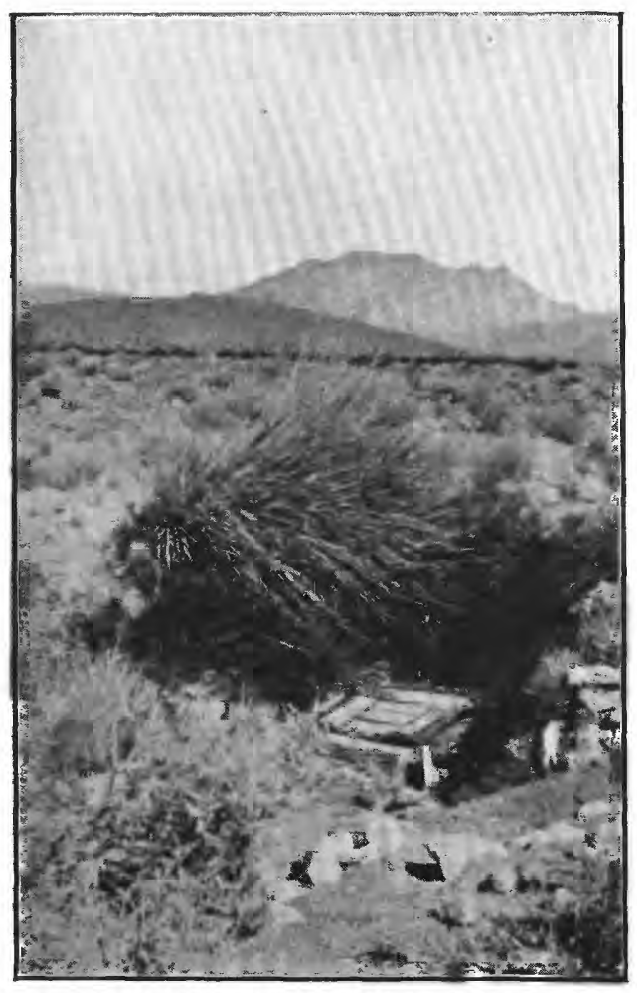

B. NEAR VIEW OF THE HIDDEN SPRING IN THE AREA SHOWN IN $A$.

All photographs by D. G. Thompson.

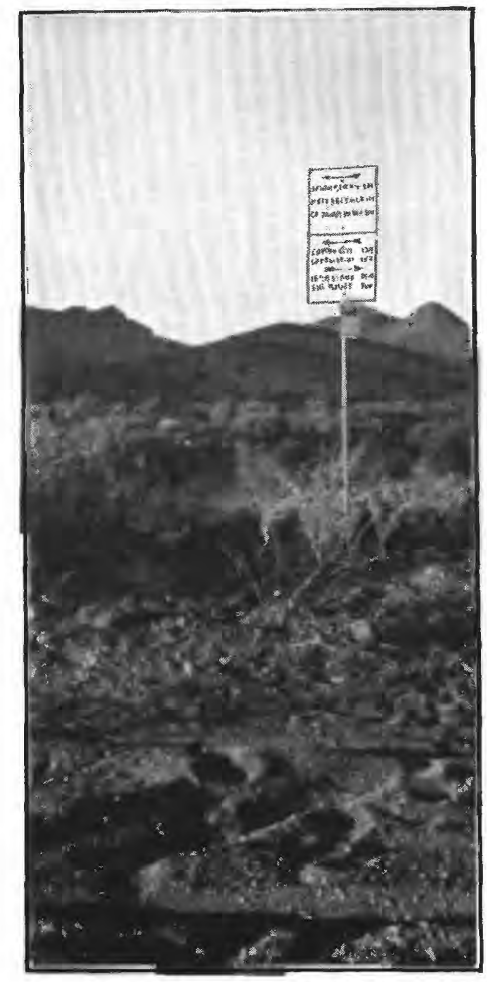

C. UNITED STATES GEOLOGICAL SURVEY SIGNPOST DIRECTING TO THE SPRING SHOWN IN $B$.

The top sign reads "Indian Spring 2/10 M. Fifty feet north of road in wash." 

where one can not travel from one watering place to the next in a day's journey, even on foot.

KINDS OF WATERING PLACES.

The usual watering places are springs or wells. Springs are frequently clogged with gravel or rubbish or sometimes even with the bodies of dead animals, and it may be necessary to clean them out. For this work a shovel is needed. Wells may or may not be equipped with pumps. Frequently the pumps are broken and useless, and a rope and bucket are then necessary to obtain water. Most of the wells in this region are less than 100 feet deep, but some are deeper, and 100 feet of rope is not too much to provide. As a rule the rope and bucket at a well, if they were ever provided, soon disappear, and one should never trust the chance of finding them there. Open wells are sometimes contaminated in the same way as springs and need to be cleaned out, particularly in little-frequented places where they, are unused for months at a time.

\section{INDICATIONS OF WATER.}

Water usually occurs in the lowest parts of the broad valleys or in canyons and gulches in the mountains: Plants are sometimes a useful indication of its presence. For instance, in this part of California a clump of palm trees is a reliable sign of water, though sometimes the water may be bad or it may be necessary to dig a foot or two for it at the base of the palm trees. Certain mesquite trees, particularly the creeping variety, are often indicators of water, especially where an isolated clump appears along a stream course. Tules (rushes) are also a reliable indication of water. There are, however, many desert plants which depend entirely on the scanty rainfall and do not indicate permanent water.

Numerous agencies, private and official, have erected signposts at different places in this region which call attention to watering places. A particular effort was made to place Geological Survey signs near water holes which were so situated as to be easily overlooked. (See Pl. IV.)

\section{GE'TITING LOST.}

The main roads are usually very plain and are adequately signposted by public and private agencies, so that there is little danger of getting lost while traveling on them. However, new roads are often made and old ones are abandoned, causing uncertainty at some places. Also a branch road to an active mine may be plainer than the main road. Some of the little-used roads are so indistinct that it is often extremely difficult to follow them. To be able to get back upon the right road if one has gone astray one should form the habit 
of careful observation, noting the prominent landmarks, such as mountains and peaks, and the branch roads, signposts, and minor details of the road. One should remember, however, that the aspect of mountains is very different from different points of view. Moreover, all objects in desert regions, as a rule, appear much nearer to unaccustomed observers than they actually are. It is well to scale the distance on the map if possible before attempting to walk to any particular place. One should be able to tell directions by the stars, and it is well to carry a compass. Persons using the compass should remember that it is affected by iron or steel objects and electric currents at close distances.

If it is necessary to walk a long distance one should take a canteen of water and a pocket full of food. If the weather is warm it is better to walk by night than by day. Follow a road if possible, as the greatest danger of perishing is in wardering about where there is no road. If it is necessary to travel where there is no road take a straight course toward some star or distant landmark. Distances can be estimated by pacing, allowing about 2,000 paces to the mile.

If one meets with an accident or gets lost far out in the desert it is important not to get excited, nor to rush wildly about wasting energy and ruining self-control. Any bad situation should be thought over carefully, and a sensible solution arrived at by studying the available maps, estimating probable distances to the most certain points of relief, and then making plans to walk, wait, or signal. It should be remembered that there are usually several travelers passing every day on the main automobile roads, and on these roads help may be obtained most easily by waiting. On less frequented roads waiting is inadvisable.

\section{MAIN ROADS ACROSS THE REGION.}

Several roads or combinations of roads are available for tourists passing across this region. A traveler starting at Los Angeles generally goes eastward through Banning and the San Gorgonio Pass, then southeastward through Coachella Valley. At the south end of this valley he may turn east at Mecca and cross the uninhabited desert to Blythe, or he may continue southeastward into Imperial Valley. From Blythe a road leads eastward across Colorado River at Ehrenberg Ferry and on by several slightly divergent routes into Phoenix. Another goes south to Yuma, from which Phoenix is reached by a well-established road. From Imperial Valley two roads are available to Yuma. One, by way of Niland, follows closely the Southern Pacific Railroad; the other, by way of Holtville, crosses the Sand Hills and is the more direct route. From San Diego there is practically but one road as far as Imperial Valley, from which 


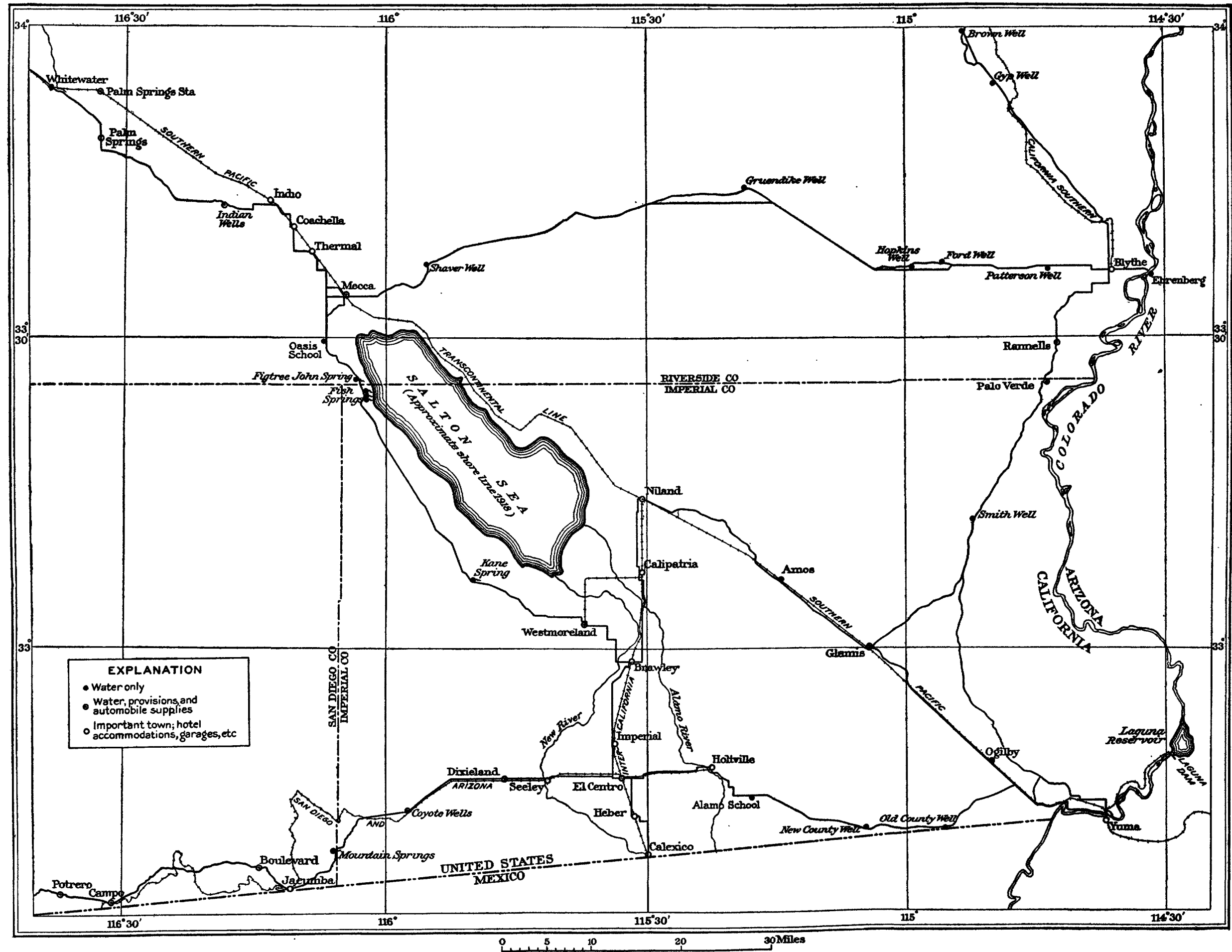

INDEX MAP OF SALTON SEA REGION, CALIFORNIA. 


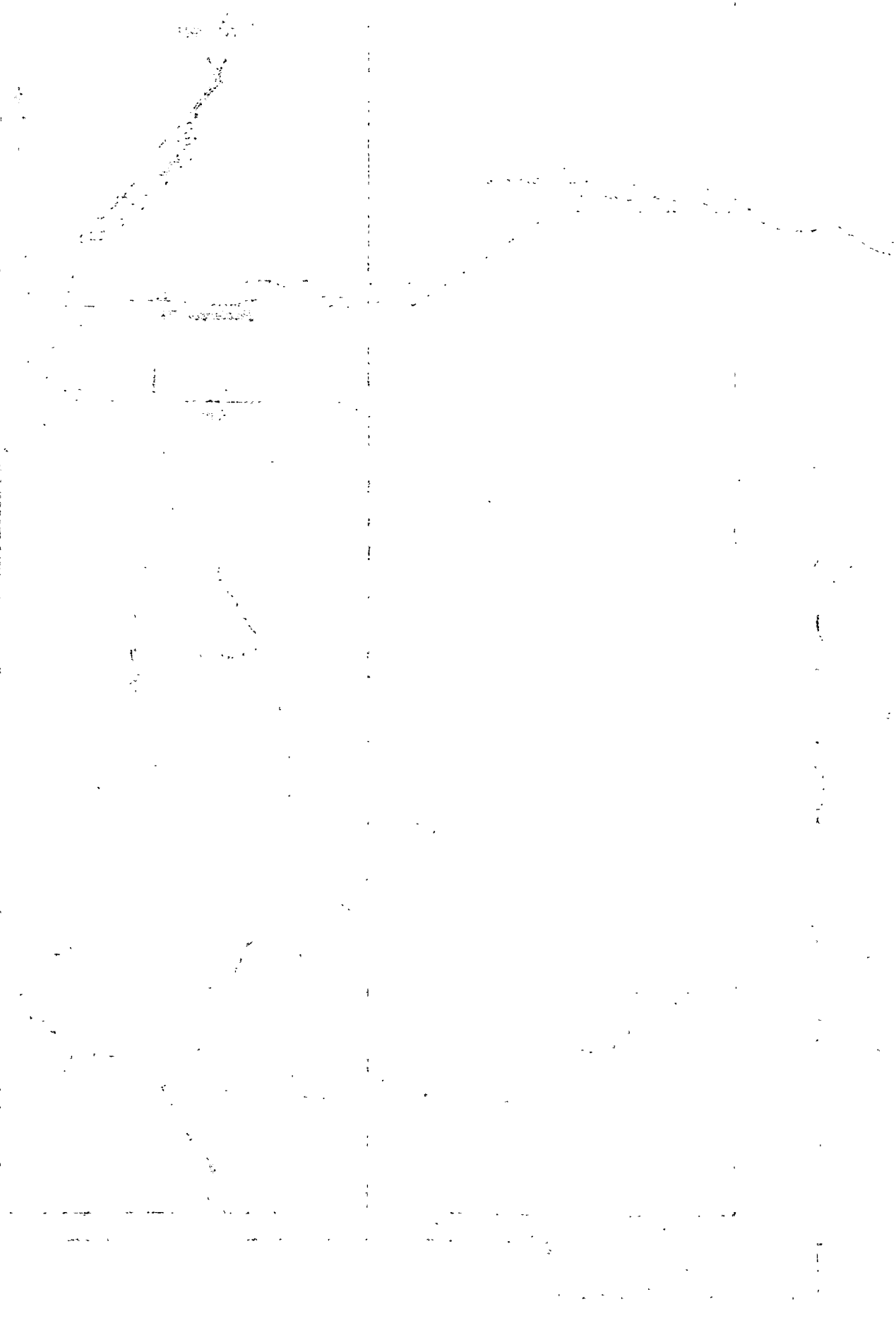


the same choice of roads as before, by Niland or Holtville, is available to Yuma. There is also an important road to Phoenix that goes from Los Angeies through San Bernardino and by way of Cajon Pass across San Bernardino County. This crosses Colorado River at Parker. Although it is the longest road to Phoenix, it has natural advantages which afford compensation for the greater distance. This road lies north of the region here considered.

The shortest route from Los Angeles to Phoenix, by way of Blythe and Ehrenberg, is about 425 miles long. The distance by way of Imperial Valley is 492 miles. The road through Cajon Pass is about 530 miles long.

\section{ROAD LOGS.}

\section{LOS ANGELES-BANNING.}

All roads from Los Angeles to Banning lead nearly due east across the thickly settled portion of southern California. Paved streets connect almost all the towns, and the network of good roads is probably unequaled 'anywhere else in the United States. The distance from Los Angeles to Banning ranges between about 83 and 94 miles, according to the route that is selected.

\section{BANNING-COACHELIA-MECCA.}

\section{BANNING TO MECCA (61 MILES).}

0.0 Banning, ${ }^{1}$ two blocks north of railway station. Start east over paved road.

1. 0 Southern Pacific Railroad. Go east along tracks.

5. 8 Cabezon railway station and store. Water and gasoline.

12.9 Geological Survey and Auto Club signs. Branch road goes northeast to Morongo Valley, etc. (See p. 71.)

13.9 Whitewater station on south side of road. Good water at faucet west of buileling.

14. 5 Cross railway and go south, away from track.

15. 2 Bridge over wide wash draining east. Usually dry, but water from Whitewater River generally discharges into this wash about 300 feet east. Road hugs mountain side after crossing bridge.

15. 6 Rock cut at Whitewater Point. , Road turns southeast.

21. 1 Turn due south.

22. 3 Palm Springs post office. Water supplies and minor repairs; hotels.

22. 6 End of pavement. Continue south on dirt road, which is usually in good condition.

24. 2 Auto Club signs. Branch road goes south to Palm Canyon. (See p. 76.) Turn east.

25.9 Road turns southeast along base of mountains.

34.0 Wooden sign on east side of road says "Water." Good water at Frey Well, one-fourth mile east of road. Little used because not near the road.

35. 1 Road turns due east.

35. 6 Road paved from this point nearly to Indio.

36. 5 Ranch house on north side of road. Water.

1 Throughout these logs heavy type is used only to denote watering places. 
37.5 Ranch house on north side of road. Water.

39. 0 Road bears southeast over region of many sand dunes covered with dense mesquite growth.

40.6 Indian Wells, store and post office. Water at trough and faucet by roadside. Gasoline.

41. 2 Cut in solid rock at point of Indio Mountain. Road continues southeast through sand dunes and mesquite.

42.5 Turn due east.

44. 0 Turn north.

44. 5 Turn east. Branch road goes west.

44. 9 End of pavement. Continue east.

46. 4 Auto Club signs. Good branch road on left goes north half a mile to Indio. Water, supplies, repairs, and hotels at town. To reach Mecca from Indio one must return to this point and continue east.

47. 0 Railway. Turn southeast along track.

48. 3 Railway crossing. Auto Club and Goodrich signs. Go due east away from track. Branch road, little traveled, continues along track.

48.9 Auto Club and Goodrich signs. Turn south (right).

49.5 Concrete pumphouse and weir of Government pumping plant for Cabezon Indian Reservation on east side of road.

49. 6 Auto Club sign. Cross railway and turn southeast beside it. Branch road goes straight south. Branch also comes in from along railway,

- northwest.

49. 8 Branch road from west crosses tracks and goes east to ranches. Main road follows railway.

50. 2 Coachella, central business block, opposite railway station. Water, gasoline, repairs, supplies, hotels. Continue southeast out of town.

50. 5 Turn due south away from railway.

51. 0 Auto Club sign. Go 100 feet east and then continue south.

52.9 Auto Club sign. Branch road goes west. Main road turns east (left).

54. 8 Auto Club and Goodrich signs. Branch road crosses railway and goes reast. Main road follows railway toward southeast.

54. 9 Thermal railway station. Water, gasoline, supplieș, hotel.

55. 7 Go south, away from railway, avoiding bad road along track.

55. 9 Crossroads. Main road turns east to railway.

56. 0 Railway. Turn to right and follow railway. Branch road goes east across track.

57. 3 Auto Club sign. Branch roads go west and east. Follow railway.

57. 6 Abandoned town of Arabia. Auto Club and Goodrich signs. Branch road turns south to Brawley. (See p. 18.) Continue along railway for shortest route to Mecca.

58. 5 Branch road goes west. Follow railway.

59. 7 Branch road goes west. Follow railway.

60. 8 Auto Club and Goodrich signs. Cross Southern Pacific Railroad. Go east into Mecca. Road south goes to Brawley. Road west also connects with Coachella-Brawley route.

60.9 Mecca post office. Water, supplies, gasoline, minor repairs, hotel. Turn south to depot.

61. 0 Water fountain just north of Mecca railway station.

MECCA TO BANNING (61 MIIFC).

0.0 Mecca water fountain, near railway station. Go north 200 feet to post office and turn west. 
0.2 Auto Club and Goodrich signs. Cross Southern Pacific tracks and turn to right following road along railway. Road south goes to Brawley. Road west connects with Coachella-Brawley route 2 miles west and may be used going either way, but route along railway is shorter to Coachella.

1.3 Goodrich sign. Branch road going west connects with Coachella-Brawley route. Continue along railway.

2.5 Branch road going west connects with Coachella-Brawley route. Follow railway.

3. 4 Auto Club and Goodrich signs. Branch road entering from south is Coachella-Brawley road. (See p. 18.) Abandoned town of Arabia just north of road fork. Continue along railway.

3. 7 Branch road goes east across railway, and 200 feet north another road goes west from railway. Goodrich sign here points west to Coachella and Banning, but one may as well continue along railway, which is shorter.

5. 0 Branch road goes east across railway. Main road turns west 0.1 mile away from railway, avoiding bad road.

5. 1 Crossroads. Turn north (right).

5. 3 Reach railway and again go along track.

6. 1 Thermal railway station. Water, gasoline, supplies, hotel.

6. 2 Auto Club and Goodrich signs. Branch road goes east across railway. Main road turns west away from railway. Continue west.

8.1 Auto Club sign. Branch road continues west. Main road turns north (right).

9. 0 Auto Club sign. Go 100 feet west and then continue north.

10.5 Railway. Follow road along railway, northwest into Coachella.

10.8 Coachella, central business block, opposite railway station. Water, gasoline, repairs, supplies, hotels. Continue northwest out of town.

11. 2 Branch road crosses track to east and another leads west. Main road follows railway.

11. 4 Auto Club signs. Branch road enters from south. Branch road continues along railway. Main road crosses to east side and goes due north away from track.

11.5 Government pumping plant for Cabezon Indian Reservation-a concrete pumphouse and well with weir, on right (east) side of road.

12. 1 Auto Club and Goodrich signs. Turn west (left).

12. 7 Railway crossing. Auto Club and Goodrich signs. Turn to right along west side of track.

14. 0 Leave railway and go straight west.

14. 6 Auto Club signs. Good branch road goes north half a mile to Indio. Water, supplies, repairs, hotels. To reach Banning from Indio one must return to this point and continue west.

16. 1 Pavement begins. Continue west.

16.5 Paved road turns south. Branch road continues west.

17. 0 Türn west, following paved road, which crosses a region of large sand dunes with heavy growth of mesquite at places.

18.5 Road turns northwest with numerous curves in next few miles.

19.8 Pass through cut in solid rock of point of Indio Mountain. General direction of road is west from cut. Region still sandy, with heavy mesquite growth.

20.4 Indian Wells, store and post office. Good water at trough and faucet by roadside. Gasoline.

22.0 Road leads due west. Dense mesquite wood on either side. 
23. 5 Ranch house on north side of road. Water. More open country.

24. 5 Ranch house on north side of road. Water.

25. 4 End of pavement. Good dirt road, partly graveled, from this point.

25.9 Road bears northwest near base of mountains.

27.0 Wooden sign on east side of road says "Water." Good water at Frey well, one-fourth mile east. Little used on account of being away from road.

35.1 Road turns due west. Big opening in mountain south leads up Palm Canyon.

36. 8 Auto Club signs. Branch road goes south to Palm Canyon. (See p. 76.) Turn north toward Palm Springs and Banning.

38.4 Pavement begins at edge of Palm Springs.

38. 7 Palm Springs post office. Water, supplies, gasoline, minor repairs, hotels.

39.9 Road bears northwest.

45. 4 Rock cut at Whitewater Point. Road turns west, hugging mountain side. 45. 8 Bridge over wide wash draining east. Usually dry, but Whitewater River generally discharges water about $\mathbf{3 0 0}$ feet east into this channel.

46. 5 Cross Southern Pacific Railroad and turn west beside track.

47.1 Whitewater railway station, on south side of road. Good water at faucet west of station building.

48.1 Geological Survey and Auto Club signs. Branch road goes northeast to Morongo Valley. (See p. 71.) Continue along railway.

55. 2 Cabezon railway station and store. Water, gasoline.

60. 0 Leave railway and go due west into Banning.

61. 0 Banning, two blocks north of railway station. Water, gasoline, supplies, repairs, hotels.

\section{COACHELLA-BRAWLEY. \\ COACHELLA TO BRAWLEY (73 MILES).}

Note.--If this trip is made by way of Mecca, use Banning-Mecea $\log$ (p. 15) as far as Mecca and see appendix to this $\log (\mathrm{p} .20)$ for road out of Mecca.

0. 0 Coachella, central business block, opposite railway station. Unless intending to pass through Mecca, take supplies for long trip. None obtainable directly on route for 64 miles, unless at small town of Thermal about 5 miles away. Go southeast out of town. Road signed.

0.3 Leave railway and turn due south.

1.8 Auto Club sign. Go 100 feet east and continue south. Numerous ranches along this portion of road.

2. 7 Auto Club sign. Branch road goes west. Main road turns east (left).

4.6 Southern Pacific tracks. Auto Club and Goodrich signs. Branch road crosses to east side of railway. Turn south along track.

4. 7 Thermal railway station. Water, gasoline, supplies, hotel. Continue along railway.

5.5 Turn south to avoid bad road along railway.

5. 7 Crossroads. Turn east to railway.

5. 8 Turn southeast along railway again.

7.1 Branch roads go east and west. Continue along railway.

7.4 Abandoned town of Arabia. Road forks here. Auto Club and Goodrich signs at fork. Turn to right, due south, to Brawley unless going through Mecca, in which case continue along tracks. The route by way of Mecca is about 2 miles longer. If desired to use that route see log for road out of Mecca (p. 20).

8.2 Branch road goes east. Continue south. 
9. 2 Crossroads. Continue south.

10. 2 Crossroads: Auto Club sign. Road on left leads 2 miles east into Mecca. Continue south.

11. 4 Branch road northeast goes to Mecca. Goodrich sign.

12.4 Branch road northeast (left) comes from Mecca. (See p. 20.) Road southwest goes to ranches. Continue straight.

13. 7 Branch road goes straight west.

14. 8 Ranch house on east side of road. Water.

15. 0 Oasis School, on west side of road. Ranch on east side. Water at either place.

15. 5 Auto Club sign. Branch road goes west.

16. 0 Auto Club sign. Branch road goes west. Main road turns southeast.

16. 4 Ranch house on east. Water. Follow best traveled road southeast. There are a number of turns and several side trails but road is adequately posted.

21. 5 Geological Survey and Goodrich signs. Water at Figtree John Spring, 0.1 mile on right-hand fork, under palm trees. Turn off to this or keep in straight road. Distances about equal.

23. 8 Auto Club sign. Road to left leads by Fish Spring, 0.2 mile away, and returns from there to straight road. About 0.1 mile longer by springs than straight road. Mileage measured by way of spring.

24. 0 Fish Spring. Water in pool, poor quality.

24. 2 Return to main road and go southwest toward base of mountains. Road rather sandy here.

25. 6 Road swings southeast, away from mountains. Mostly graded and graveled or otherwise improved.

31. 0 Paved crossing over bed of arroyo.

31.6 Wooden bridge over arroyo.

32. 4 Cabin on west side of road, headquarters for road workers. This may have been moved since 1918.

32. 5 Concrete crossing over bed of deep arroyo.

33. 0 Wooden bridge over small arroyo. Trail said to lead west up this arroyo to Seventeen Palms.

36. 0 Concrete crossing over bed of large arroyo.

37. 7 Geological Survey sign on north bank of large arroyo with concrete crossing. Trail leads west up wash to McCain Spring, 2.4 miles. Poor water.

39. 2 Cross large arroyo.

41. 8 Road bends sharply east, avoiding old beach, which circles east around point of badland hills visible from road. Several large crescentic sand dunes along each side of road in next 4 miles.

44. 3 Turn nearly south down slope to San Felipe Creek.

47. 4 Cross culvert over bed of San Felipe Creek. Water usually running here, but do not drink this water.

47. 5 Dim trail to right. Main road turns to left.

49. 0 Kane Spring reservoir on east (left) side of road. Water at pipe leading out of reservoir, poor but drinkable. Geological Survey and Auto Club signs. Branch road west to Harper Well and Borego Valley. (See p. 35.) Turn east up hill.

49. 1 Narrow pavement begins here. Read big red-letter sign giving road rules. Turnouts about every quarter mile.

56.1 End of pavement. Cross bridge over irrigation ditch and turn southeast along ditch. (Water for emergencies.)

57. 0 Auto Club sign. Go straight east away from ditch. 
58.9 Go 100 feet south and continue east. Good dirt road. Branch roads every half mile or mile serve neighboring ranches but will not be mentioned unless important. Road is adequately signed all the way to Brawley.

61.5 Good branch road north said to be short cut to Calipatria and Niland. Goodrich and Auto Club signs. Continue east.

62. 5 Crossroads. Auto Club and Goodrich signs. Turn south (right).

63. 0 Auto Club sign. Branch road continues south. Turn east.

63. 3 Cross tracks of branch line Inter-California Railway.

63. 5 Auto Club sign. Turn south (right).

64. 0 Westmoreland store and post office. Auto Club signs. Water, gasoline, and provisions. Turn east. Branch roads go south and west.

66. 5 Auto Club and Goodrich signs. Highway turns south at crossroads.

71. 5 Auto Club and Goodrich signs. Turn east (left) down hill.

71. 6 Bridge over New River.

72. 0 Palm-lined street (Main Street) leads into Brawley.

73. 0 Paved street. Auto Club signs. Continue east to railway station. Road south (right) around triangular court leads to Imperial and El Centro.

73. 3 .Brawley, railway crossing at station.

\section{MECCA TO BRAWLEY.}

0. 0 Mecca, water fountain near railway station. Go north to post office and turn west.

0.2 Cross Southern Pacific Railroad and turn south (left). Road along railway to northwest goes to Coachella. Road to west may be used to Brawley or Coachella, connecting with highway 2 miles west.

1.2 Auto Club sign. Crossroads. Turn west.

1.9 Auto Club sign. Turn southwest. Several trails lead to left at various places, but try to keep main road going southwest.

3. 6 Reach Coachella-Brawley road and turn straight south. Set to 12.4 for mileage from Coachella and use Coachella-Brawley $\log$ (p. 18). It may be possible to get astray in branch roads before reaching this point, but all lead into highway at no great distance, and some point beyond, like Oasis School or Figtree John Spring, can be identified and reạdinigs corrected to suit.

\section{BRAWLEY TO COACHELLA (73 MILES).}

Note.-An appendix to this $\log$ (p. 22) gives route into Mecca from the point where it diverges from the Coachella road. If the Mecca road is used follow Mecca-Banning Iog out of Mecca (p. 16).

0.0 Brawley, railway crossing at station. Go west on Main Street.

0.3 Auto Club signs. Road south (left) around triangular court leads to Imperial and EI Centro. Continue west.

1.6 Bridge over New River.

1.8 Auto Club and Goodrich signs. Turn north (right). The region for next 15 miles is well settled, and branch roads every half mile or mile serve neighboring ranches. Only the important roads will be mentioned. Road is adequately posted.

6. 8 Highway turns west (left) at crossroads. Auto Club and Goodrich signs.

9. 3 Westmoreland, store and post office. Water, gasoline, and provisions The last supply station for 64 miles unless passing through Mecca, which is 55 miles away. Turn north (right).

9. 8 Auto Club sign. Turn west (left).

10. 0 Cross track of branch line Inter-California Railway.

10. 3 Auto Club sign. Turn north. 
10.8 Auto Club and Goodrich signs. Turn west at crossroads.

11. 8 Goodrich and Auto Club signs. Good branch road north, said to go to Calipatria and Niland.

14. 4 Go 100 feet north and continue west.

16. 3 Auto Club sign. Turn northwest along irrigation ditch.

17. 2 Turn west across ditch and start on narrow concrete road. Read big red-letter signboard giving traffic rules. Turnouts provided about every quarter mile.

24. 2 End of paved road.

24. 3 Geological Survey and Auto Club signs. Turn to right around Kane Spring reservoir. Road to left goes to Harper Well, Borego Valley, etc. (S'ee p. 35.) Water at pipe out of reservoir is drinkable but not good.

25. 8 Dim trail to left. Turn right across San Felipe Creek.

25. 9 Culvert over San Felipe Creek. Usually running water of bad quality. Do not drink.

29. 0 Turn west around point of badland hills at foot of which lies old beach (very sandy). There are numerous isolated crescentic sand dunes along the road here.

31.5 Road turns more to north.

34. 1 Cross large arroyo.

35. 6 Concrete crossing over bed of deep arroyo. On north bank of this wash is Geological Survey sign. Trail leads up bed of wash to McCain Spring, 2.4 miles away. Poor water but drinkable.

37. 3 Concrete crossing over bed of large arroyo.

40. 3 Wooden bridge over arroyo. Trail said to lead west up this arroyo to Seventeen Palms.

40. 8 Concrete crossing over bed of large arroyo.

40.9 Cabin on west side of road, headquarters for road workers. This may have been moved since 1918.

41. 7 Wooden bridge over small arroyo.

42. 3 Concrete crossing over bed of arroyo.

47. 7 Road, which has approached base of mountains, swings northeast away from it. Rather sandy here.

49. 1 Auto Club sign. Branch road to right goes to Fish Spring, 0.2 mile away, and returns to straight road farther on. Mileage was measured on this branch.

49. 3 Fish Spring. Poor water in pool.

49.5 Return to straight road.

51. 7 Branch road to left leads to Figtree John Spring, under palms 0.1 mille away. Good water.

51. 8 Geological Survey and Goodrich signs point to Figtree John Spring. From this point road is crooked for several miles, and numerous trails turn off, but main road is distinct and easy to follow. Well signed.

56. 9 Ranch house on east. Water.

57.3 Auto Club sign. Turn straight north (right). Branch road leads west.

57. 8 Auto Club sign. Branch road west.

58. 3 Oasis School on west side of road. Ranch house on east. Water.

58. 5 Ranch house on east. Water.

59. 6 Branch road leads west.

60.9 Branch road northeast (right) goes to Mecca. See appendix to this log (p. 22). One may also turn off later for Mecca, but this road is shortest. Continue north to Coachella.

61. 9 Goodrich sign. Branch road northeast goes to Mecca. Little traveled. 
63. 1 Crossroads. Auto Club sign. Mecca is 2 miles due east. Continue north to Coachella.

64. 1 Crossroads. Continue north.

65. 1 Crossroads. Continue north.

65. 9 Southern Pacific Railroad. Auto Club and Goodrich signs. Turn northwest along track. Road from southeast comes from Mecca. Pass through abandoned town of Arabia here.

66. 2 Crossroads. Roads run east and west. Continue along railway.

67. 5 Turn west, away from track, to avoid bad road.

67. 6 Crossroads. Turn north to railway again.

67.8 Follow railway northwest.

68. 6 Thermal railway station. Water, gasoline, hotel.

68. 7 Auto Club and Goodrich signs. Turn west, away from railroad. . Branch road crosses to east side of railway.

70.6 Auto Club sign. Branch road continues straight. Main road turns north.

71. 5 Auto Club sign. Go 100 feet west and continue north.

73. 0 Turn northwest near railway into Coachella.

73. 3 Coachella. Central business block, opposite railway station.

Note.-If continuing to Banning see $\log$ on page 16.

\section{TO MECCA FROM BRAWLEY ROAD.}

60.9 Take right-hand road northeast. May be several trails, but all go to the same place.

62. 6 Auto Club sign. Turn straight east.

63. 3 Crossroads. Auto Club sign. Turn north (left).

64. 3 Southern Pacific Railroad. Cross tracks and go east into Mecea. Road along tracks here goes to Coachella and road straight west intersects Brawley-Coachella road.

64. 4 Mecca. Post office and hotel. Turn south to water fountain and railway station.

64.5 Mecea railway station.

\section{BRAWIEY-NILAND.}

\section{BRAWLEY TO NILAND (20 MILES), •}

0.0 Brawley. Railway crossing and station. Go east.

1. 2 Auto Club signs. Turn north at crossroads.

5. 7 Turn west a few hundred feet, then north again along railway. Road is signed.

7. 3 Cross Alamo River and continue north along railway.

10.7 Turn west, crossing railway. Road is signed.

11. 0 Turn north at crossroads. Road is signed.

12. 0 Cross main street of Calipatria. Continue north.

12.5 Turn west. Road is signed.

12.8 Turn north. Road is signed.

18. 8 Turn east.

18.9 Turn north again. Road is signed.

20. 4 Niland. Corner by post office, one block south of railway station. Geological Survey sign.

NILAND TO BRAWLEY (20 MILES).

0. 0 Niland. Corner by post office, one block south of railway station. Geological Survey sign on corner. Go south. There are crossroads every 
half mile or mile along this highway, but only the important ones will be mentioned.

1.5 Turn west (right). Road is signed.

1.6 Turn south. Road is signed.

7. 6 Auto Club signs. Turn east.

7.9 Turn south. Road is signed.

8. 4 Cross main street of Calipatria. Continue south.

9. 4 Auto Club signs. Turn east at crossroads.

9. 7 Cross railway and turn south along track.

13. 1 Cross Alamo River and continue south along railway.

14. 6 Turn a few hundred feet east, away from railway, and go due south. Road is signed.

19. 2 Crossroads. Auto Club and Goodrich signs. Turn west.

20. 4 Brawley, at railway crossing and railway station.

\section{NILAND-GIAMIS-YUMA.}

NILAND TO YUMA (73 MILES).

0. 0 Niland. Gorner by-post office, one block south of railway station. Geological Survey sign on corner. Go east.

0. 2 Cross Southern Pacific Railroad and turn southeast along north side of track.

0.5 Auto club sign. Plain road leads north. Continue along track.

3. 7 Turn east, away from track, crossing East Highline canal of Imperial Irrigation District, about 100 feet from the railway. A dim road leads southeast (right) along track to Flowing Well, a railway station half a mile away. Go straight ahead, up hill that marks old beach. This is very sandy. It may be necessary to deflate tires to about 35-pound pressure here.

4. 5 Top of hill. Follow main road.

6. 8 Plain trail turns to left up large wash. There are numerous tracks in next 3 miles that turn to the left toward the Chocolate Mountains. Some of these go to Salvation Spring. (See p. 57.) Ignore them and continue southeast on main traveled road.

8.9 Another very plain trail leads to left toward mountains. Continue straight ahead. There are bad sandy spots in next 3 miles.

14. 4 Auto club sign. Cross trail running northeast and southwest. Go straight ahead.

15. 5 Auto club sign. Faint trail continues straight ahead but main road turns to right, toward railway.

16. 2 Railway. Cross and go southeast along track. A dim branch road comes down railway from Mammoth Wash.

19. 3 Amos railway station. Water obtainable from cistern supplied by railway company. Charge of 5 cents per head for stock. Continue along

- south side of track.

32. 7 Pass Glamis railway station, which is on north side of railway, and continue southeast 0.1 mile.

32.8 Cross to north side of track and turn back northwest to railway station.

32.9 Glamis railway station. Water can be had from railway cistern. Charge for stock. Gasoline and meals are obtainable, at store. To leave Glamis go northeast, away from railway, on main road, which is well signed. 
33. 1 Road forks. Auto club sign. Left-hand road continues northeast to Blythe. Right-hand road turns southeast to Yuma. Road parallels railway but keeps at a distance.

37.9 Turn south toward railway.

38. 9 Cross track to south side of railway. A dim branch road comes in.down railway. Turn southeast beside track.

52.1 Ogilby railway station. Water is obtainable from cistern kept by railway company. Gasoline can be purchased. Continue along railway.

56. 0 Branch road comes in from southwest. This is the Sand Hills or Holtville route to Yuma. Continue along railway.

58. 8 Road forks. Goodrich sign. Right-hand road continues along railway into Yuma, passing close to Colorado River for last 5 miles. This road is very hilly and sandy and consequently less traveled. Left-hand road crosses railway and goes north. Optional logs given.

Left-hand or " mesa" road.

58. 8 Cross railway and go north.

59. 8 Dim road goes to left. Continue to right.

61.9 Geological Survey sign. Branch road goes northwest to Blythe. Turn southeast here on main road.

65. 0 Descend hill and follow sandy wash $1 \frac{1}{2}$ miles, passing through cut in river terrace, 50 feet high.

66. 5 Branch road goes southwest. Turn left (east) along irrigation ditch.

67. 4 Turn south (right).

67.9 Touch railway and turn east (left). Branch road crosses railway to south.

70.1 Cross bridge over very large canal.

70. 2 Bridge over large canal.

70. 9 Geological Survey sign at crossroads. Turn south to Yuma.

72. 4 Cross a railway track and turn east, uphill, to bridge over Colorado River. River road (right-hand branch) joins here. Fort Yuma Indian School on hill.

72. 5 California side of bridge over Colorado River. Follow principal streets into Yuma.

72.9 Yuma, Ariz., at post office or railway station.
Right-hand or river road.

58. 8 Take right-hand road, continuing along track.

63. 2 Turn south (right), away from railway, along levee.

64. 2 Turn east, along levee. Exact course of road not known here but it goes nearly east into Yuma. Follow main road.

67. 3 (Approximate distance.) Winterhaven. Small village. Water, store and supplies.

68. 2 Pass under railway bridge and turn north; ùphill.

68. 3 Join left-hand road and turn east uphill to bridge over Colorado River. Fort Yuma Indian School on hill.

68. 4 California side of bridge. Follow principal street into Yuma.

68. 8 Yuma, Ariz., at post office or railway station. 
YUMA TO NILAND (73 MILES).

0. 0 Yuma. At post office or railway station. Follow principal streets to bridge over Colorado River.

0.4 California side of bridge.

0.5 Road forks. Left-hand road follows river and railway. Right-hand road crosses valley and "mesa." The right-hand road is most used. Optional logs are given.

Left hand or river road.

0.5 Turn south, pass west under railway bridge, go north a few hundred feet, then west. . This route was not traversed, but goes approximately west. Follow main road.

1.5 (Approximate distance.) Winterhaven. A little village. Water, store, supplies.

Continue west, taking a course along levee.

4. 6 Turn north along levee.

5. 6 Turn west (left) along south side of railway. Ground badly dissected, hilly, and sandy. Sand may give trouble.

.10. 0 Right-hand road comes in from north, across track. Goodrich sign. Set to 14.1 and follow railway.

\section{Right-hand or " mesa" road.}

0.5 Cross railway track and turn to right around hill on which is Indian school. Then go due north.

2. 0 Geological Survey sign. Road north goes to Picacho (p. 63), road east to Laguna dam (p. 63). Turn wešt to Niland.

2. 7 Cross bridge over large canal.

2. 8 Cross bridge over very large canal.

5. 0 Road touches railway and turns north (right). Branch road leads south across railway.

5. 5 Turn west (left).

6. 4 Turn north (right), passing up wash through heavy sand for $1 \frac{1}{2}$ miles. A branch road leads southwest at this point.

11. 0 Road forks. Geological Survey and Auto Club signs. Most travelers take left-hand road to Ogilby. One may, however, continue west and make a cutoff by utilizing some good but little-traveled roads.

14. 1 Goodrich sign. Cross railway and join river road.

14.1 Proceed northwest along south side of track.

16. 9 Auto Club sign. Branch road goes southwest, away from track. This is the "Sand Hills" or Holtville route to El Centro. Continue along track.

20.8 Ogilby railway station. Water is obtainable from a railway cistern. Charge of 5 cents per head to water stock. Gasoline. The branch road mentioned under 11.0 on right-hand road comes in here. A number of trails lead northeast to points in the mountains and to an intersection with Tumco road. (See p. 61.) A road also goes south to Holtville road. Continue along railway.

34. 0 Cross track to north side of railway. A branch road continues along track but is very sandy.

35. 0 Turn west, paralleling railway but keeping at a distance.

39. 8 Branch road goes northeast to Blythe. Auto Club, signs. Turn southwest into Glamis. 
40. 0 Glamis railway station. Water obtainable from railway company. Charge for stock. Gasoline and, meals obtainable at store. To leave Glamis, turn east at station along north side of railway.

40.1 Cross to south side of track and turn back northwest. Road is well signed.

53.6 Amos railway station. Water obtainable from railway company. Charge for stock. Continue along south side of track.

56. 7 Cross railway and go northwest, away from track, avoiding bad sand in Mammoth Wash. A dim road continues along railway.

57. 4 Auto Club sign. Faint trail southeast. Continue northwest.

58.5 Cross trail running northeast and southwest. Auto Club sign. There is some bad sand in next 3 miles.

64. 0 Trail leads northeast up big wash. A great many tracks turn off in this direction in the next 3 miles, some of which undoubtedly lead to Salvation Spring. (See p. 57.) Keep the main traveled road westward.

66. 1 Very plain road goes northeast, up wash. Continue west.

68.4 Top of hill marking old beach. There is very deep sand here but it is not often troublesome in descending.

69. 2 East Highline canal of Imperial Irrigation District. Cross canal and take road northwest along railway, which is reached at this point. A branch road goes southeast to Flowing Wells, a railway station half a mile away, but it is very sandy.

72.4 Auto Club sign. Branch road goes northeast. Continue along railway.

72. 7 Cross railway and go west into Niland.

72.9 Niland. Corner by post office, one block south of depot. Geological Survey and Auto Club signs. Main road leads south to Brawley and El Centro, from which routes lead to Los Angeles and San Diego.

\section{BRAWLEY-EL CENTRO.}

BRAWLEY TO EL CENTRO (15 MILES).

0. 0 Brawley. At railway crossing and station. Go west on paved street.

0. 3 Auto Club signs. Turn southwest (left) around triangular park. Road west goes to Los Angeles.

0. 4 Turn due south.

0.6 Auto Club sign. Turn west off of paved streets.

0.9 Turn southwest (left).

1.1 Leave city streets and go nearly south along canal.

2.3 Road bears southwest.

3. 4 Auto Club and Goodrich signs. Turn due south across canal.

9.9 Reach paved streets of Imperial.

10. 4 Imperial. Main Street. Big sign in center of street crossing. Oross Main Street and continue south.

10.9 End of pavement. Continue south on good road.

13.9 Geological Survey sign. Paved road goes west to San Diego. Continue south to El Centro.

14. 2 Turn east on paved street.

15. 1 GI Centro. At railway crossing and station.

EL CENTRO TO BRAWLEY (15 MIIES).

0. 0 El Centro. Railway crossing and station. Go west.

0. 9 Turn north on paved street.

1. 2 Geological Survey sign. Paved street goes west to San Diego. For Brawley continue north on good dirt road. 
4. 2 Paved street of Imperial.

4. 7 Imperial. Main Street. Cross Main Street and continue north.

5. 2 End of, paved street. Continue north.

11. 7 Auto Club sign. Cross canal and turn northeast.

12.8 Road turns nearly north.

14. 0 Auto Club sign. Turn northeast on streets of Brawley.

14. 2 Turn due east (right).

14.5 Auto Club sign. Paved street. Turn north (left).

14. 7 Turn to right around triangular park.

14. 8 Turn due east (right) on Main Street. Road west goes to Los Angeles. (See p. 20.)

15.1 Brawley. Railway crossing at station. For Niland continue east. (See p. 22.)

\section{SAN DIEGO-JACUMBA.}

The highway between San Diego and El Centro forms a part of the coast route from Los Angeles to Imperial Valley, Yuma, and Phoenix. Several inland routes leading from Los Angeles connect with this highway near Campo and about 20 miles west of Jacumba.

The route from San Diego to Jacumba, about 76 miles, lies mainly on the Pacific slope and crosses well-settled country where agriculture and grazing are the principal industries and where water is relatively plentiful. Fọr fruit raising or agriculture, irrigation is generally practiced, but it is only beyond Jacumba that the change from a well-watered country to a desert becomes marked. Tourists are referred to the Automobile Club of Southern California, the Goodrich Touring Bureau, and the standard guides for information about roads and places. No Geological Survey signs will be seen until the desert is reached.

\section{JACUMBA-EL CENTRO.}

\section{JACUMBA TO EL CENTRO (46 MILES).}

0. 0 Jacumba. Front of hotel and camp by springs. Auto Club signs. Store on south side of road. Go east.

5. 7 Cabin on south side of road. Road leading north goes to Smuggler Spring, one-fourth mile away.

8. 7 Mountain Springs. Store. Water.

8. 8 Mountain Springs. Water trough. Follow down canyon.

14.0 Bridge over canyon at edge of mountains. Pavement begins.

14. 8 Leave mountain wall and start over desert plain.

16. 0 Pass under railway bridge.

20. 0 Coyote Wells. Store, post office, and railway station. Water.

22.9 Trail ledding north goes to marble quarry.

26. 1 Road turns due east.

28. 8 Geological Survey sign. Branch road leading north goes to Carrizo and Julian. (See p. 41.)

30. 8 Road northwest goes across desert to Carrizo. Road leading south goes to Yuha Wells. (See p. 45.)

32. 1 Dixieland. Water, gasoline.

36. 3 Go south 0.2 mile, then east across New River, then north to line of straight road, then east. This part not paved. When the new bridge is completed this jog will not be made.

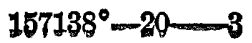


36. 8 Go east on boulevard.

37. 2 South edge of Seeley. Water, supplies. Road goes northwest 1 mile.

38. 2 Turn due east across railway.

44. 5 Geological Survey, Auto Club, and Goodrich signs at west edge of E]

Centro. Go south over paved road.

44. 8 Turn east to center of town.

45. 4 Auto Club sign at street corner.

45. 6 El Centro railway station.

\section{EL CENTRO TO JACUMBA (46 MILES).}

0. 0 El Centro railway station. Go west.

0. 2 Auto Club sign at street corner. Continue' westward.

0. 9 Turn north, following paviement.

1.1 Geological Survey and Auto Club signs. Turn west on pavement.

7. 4 Cross railway. Go southwest 1 mile through seeley.

8. 4 Seeley. Water, supplies. Road turns due west again.

8. 8 Go south 0.1 mile, then west over New River, then north again. This road not paved. If new bridge is completed this road will be straight.

9. 3 Go west on pavement in line with Seeley.

13. 5 Dixieland store. Water.

14. 8 Branch road goes northwest to Carrizo, but better road to Carrizo farther on. Branch road leading south goes to Yuha Wells. (See (p. 45.)

16. 8 Geological Survey sign. Road leading north goes to Carrizo and Julian. (See p. 41.)

19. 5 Boulevard turns southwest.

22. 7 Trail leading north goes to marble quarry.

25. 6 Coyote Wells. Water, store, post office, and railway station.

29. 6 Pass under railway bridge.

30. 8 Road skirts mountain walls.

31. 6 Bridge over canyon. End of pavement. Follow main traveled road along canyon and over mountains.

36. 8 Mountain Springs. Water trough.

36. 9 Mountain Springs store. Water.

39. 9 Cabin on south side of road. Branch road leading north goes to Smuggler Spring, one-fourth mile away.

44. 2 Descend into Jacumba Valley.

45. 6 Jacumba. Hotel, camp, and springs, on north side of road. Store on south side. Auto Club signs.

EL CENTRO-YUMA.

EL CENTRO TO YUMA (67 MILES).

0. 0 El Centro railway station. Go east.

0.9 Auto Club sign. Branch road leads south to Calexico. Continue east.

2. 4 Auto Club sign. Turn north (left).

2. 7 Holtville Interurban Railway. Cross railway and turn east along it.

6. 4 Meloland store.

8. 8 Auto Club sign. Turn north, away from railroad.

9. 2 Auto Club sign. Turn east to Holtville.

9. 7 Bridge over Alamo River.

10. 6 Holtville. Northwest corner of open square containing city hall. Turn south one block. Post office on right. 
10. 7 Turn east from post-office corner at southwest corner of square.

11. 0 Auto Club sign. Turn south.

11.4 Cross canal bridge. Turn southeast.

13. 1 Turn south.

13.9 Turn east.

14. 6 Auto Club sign. Turn south.

15.5 Auto Club and Goodrich signs. Branch road leads south to Calexico. Go east for Yuma.

17. 5 Alamo School. Water at faucet on ground just west of elevated iron tank. Geological Survey sign on corner, also store. Continue east.

19. 2 Highline canal at east edge of Imperial Valley. Cross and start east over desert. Heavy sand at first. Read big warning board of Auto Club. Many trails cross and recross over next 20 miles, but all eventually return to main road. Pick out the best or plainest road. Numerous Auto Club signs, but travelers may not pass near enough to see them.

30.9 New County Well. Windmill. Good water. Nearly all tracks pass this well. Next 10 miles very sandy.

40. 4 Planked road that crosses Sand Hills.

40. 6 Old County Well and roadmen's house. Good water. Electric tranşmission line crosses road several times in next few miles.

47. 2 Planked road ends. Good road beyond.

47. 3 Geological Survey sign. Road north (left) is cut-off to Ogilby. Road along electric transmission line is used, by linemen and branches to right, disappearing from main road.

50. 2 Southern Pacific Railroad. Auto Club and Goodrich signs. Follow railway southeast.

53. 0 Goodrich sign. Road forks. Right-hand road, following railroad and river, is the shorter but is hilly and very sandy. Left-hand road is best. Optional logs given.

Left-hand or mesa road.

53. 0 Cross railroad and go north.

54. 0 Branch road on left. Take righthand fork.

56. 1 Geological Survey and Goodrich signs. Turn southeast. Road leading west goes to Ogilby, also to Blythe (p. 62).

59. 2 Enter sandy wash.

60. 7 Turn east along irrigation ditch.

61. 6 Turn south.

62.1 Railroad. Turn east.

64. 3 Bridge over yery large canal.

64. 4 Bridge over large canal.

65. 1 Geological Survey sign. Road north leads to Pichaco (p. 63). Road east to Laguna dam (p. 63). Turn south for Yuma.

66. 6 River road comes in just west of bridge at Indian school.
Right-hand or river road.

53. 0 Follow railroad southeast.

56. 4 Turn south, away from railroad, along levee.

57. 4 Turn east, along levee. In general, route is east into Yuma, but route was not traversed.

61.5 (Approximate distance.) Winterhaven. Small village. Water, store, and supplies.

62. 7 Railroad bridge, pass under and turn to the left. Road joins mesa road at 63.0, just west of bridge. Set gage to 66.6 . 
66. 7 Bridge over Colorado River. Follow principal streets into Yuma.

67. 1 Yuma. At railway station or post office. The two are about three blocks apart, but equal distances from bridge.

YUMA TO EL CENTRO (67 MILES).

0. 0 Yuma. Post office or railway station. Follow principal streets to bridge over Colorado River.

0.4 California side of bridge.

0. 5 Road forks. Left-hand road follows river and railway and is sandy and hilly. Right-hand road crosses valley and "mesa" and is most used. Optional logs given.

Left-hand or river road.

0.5 Turn south, pass west under railway bridge, go north a few hundred feet, then west. This road was not traversed but goes approximately west. Follow main road.

1.5 (Approximate distance.) Winterhaven. Small village. Water, store, and supplies. Continue west along levee.

4. 6 Turn north along levee.

5. 6 Turn west (left) along south side of railway. Cross much hilly, sandy land. Sand may give trouble.

10. 0 Mesa road comes in across railway. Goodrich sign. Set gage to 14.1
Right-hand or " mesa" road.

0.5 Cross railway and turn around hill on which is Indian school. Then go due north.

2. 0 Geological Survey sign. Road leading north goes to Picacho (p. 63). Road leading east goes to Laguna dam (p. 63). Turn west for Imperial Valley or Blythe.

2. 7 Bridge over large canal.

2. 8 Bridge over very large canal.

5. 0 Railway. Turn north (right).

5. 5 Turn west (left).

6. 4 Road forks. Turn north (right). Pass up wash for $1 \frac{1}{2}$ miles. Heavy sand.

11. 0 Geological Survey and Goodrich signs. Turn south (left). Road leading west goes to Ogilby. Road leading west goes to Blythe (p. 62).

14. 1 Railway. Cross. River road comes in here. Goodrich sign.

14. 1 Turn northwest along railroad.

16.9 Auto Club and Goodrich signs. Turn southwest (left) away from railroad. Road along railway goes to Niland (see p. 25).

19. 8 Electric transmission line. Geological Survey sign. Road leading north is cut off to Ogilby. Road along electric transmission line is used by linemen.

19. 9 Planked road crossing Sand Hills begins.

26. 5 Old County Well and roadmen's house. Water. West edge of Sand Hills.

26. 7 End of planked road. Follow best or plainest track. Many winding trails cross and recross, but all eventually unite. For this reason 
traveler may not pass Auto Club signs erected at numerous places on route. In general keep west. The next 5 miles are very sandy.

36. 2 New County Well. Windmill. Good water.

47. 9 Highline canal at east edge of Imperial Valley. Cross and go west.

49.6 Alamo School. Geological Survey sign. Store. Water at faucet on ground west of elevated iron tank.

51.6 Auto Club and Goodrich signs. Go north (right) for Holtville and El Centro.

52. 5 Road turns west. Auto Club and Goodrich signs.

53. 2 Road turns north.

54. 0 Road turns northwest.

55. 7 Canal bridge. Cross and turn north.

56. 1 Auto Club sign. Turn west and go into Holtville.

56. 4 Holtville. Southwest corner of open square containing city hall. Post office is just north. Go north one block and then turn west for $\mathrm{El}$ Centro.

57. 4 Bridge over Alamo River.

57.9 Auto Club sign. Turn south (left).

58. 3 Holtville Interurban Railway. Turn west along railway.

60. 7 Meloland store.

64. 4 Road crosses railroad and goes south.

64. 7 Auto Club sign. Turn west (right).

66. 2 Auto Club sign. Road leading south goes to Calexico. Keep west for El Centro.

67.1 El Centro. At railway crossing and depot.

WARNER-BOREGO VATLEY-BRAWLEY.

WARNER TO BRAWLEY (91 MILES).

0. 0 Warner Hot Springs. Post office. Take supplies enough to last 80 miles. Start east. The road has changed somewhat recently, and it may be well to make local inquiry before starting. Ascend a steep hill just east of Warner. The first 6 miles of this road is not very thoroughly known.

1. 8 Cross Canada Verde, a little creek of running water.

2.9 Branch road goes east. Continue south on plainest road. There may be dim trails and tracks to either side at a number of places.

5. 9 Just on top of a little granite hill the road forks. Geological Survey sign. The road southeast continues straight ahead to San Felipe Valley, etc. (See p. 38.) Turn east (left) toward Borego.

8.1 Branch road leads north (left) to a mine visible on the mountain side about a mile away. Continue east.

8. 2 Pass through a gate, the boundary of Warner ranch.

8. 4 Branch road goes east (left) to Montezuma. This may be better traveled than the Borego road. Turn southeast (right) to Grapevine Canyon and Borego. There are usually wooden signs at this fork.

10. 2 Summit of divide. Turn down Grapevine Canyon to southeast. The road is narrow and rocky but passable.

11. 5 A trail leads to the left up a side canyon. Continue southeast.

11. 7 A trail leads to the left, to a cabin half a mile away. Another trail leads to this 0.2 mile farther on. Continue southeast. 
11.9 A trail leads to left, to a cabin half a mile away. There is water at this cabin and the road is passable, but water is also obtainable nearer the road farther on. Continue to the right, on plainest road.

12. 0 Grapevine Spring. Water about 150 feet off the road to the right in the wash, the upper part of the spring. The road goes southeast down a steep hill.

12. 5 A cabin stands in the little valley on the right, and water is obtainable in the cangon. Turn to the left, continuing down the canyon.

13. 9 Geological Survey sign on north side of road. Water trough at a spring 100 feet north. This is called Stuart Spring, or Sumac Spring. Continue east, down the canyon.

21. 4 Geological Survey sign on north side of road. There is usually a little pool of poor but drinkable water in a hole 100 feet north. This is called Yaqui Well. Continue east, down the canyon.

22. 4 The road crosses from north to south side of the big sandy wash which occupies the bed of the canyon. This is often troublesome on account of sand. Continue east, on south side of wash, on a sort of terrace.

26. 0 At about this point the road descends from the little terrace to the bed of the wash and continues east.

27.0 The Narrows, a gorge about 300 feet wide, through which the road passes. Geological Survey sign at lower end of gorge. Road to Borego turns to the left out of the wash and goes north across a broken divide. A branch road, sometimes obscured at this place, leads east, down the wash (right) and reaches Brawley, effecting a cut-off of several miles. At one time this was a country road, but in 1918 it was very bad. See appendix to this $\log$ ( $p .34$ ). Take road to left and disregard a few dim trails leading east (right).

32. 1 Pass little cabin on right (east) of road.

33. 6 House on left (west). Water at flowing well in yard. Continue northwest.

33. 9 Geological Survey sign. Road straight ahead goes to ranches in Borego Valley. Take road which turns east to go to Brawley.

36. 7 Road splits around a clump of green trees and a little wire-fenced corral. Take either branch.

36. 8 Borego Spring in clump of trees. Cattle trough. Good water in barrel buried in the center of the bushes. Geological Survey sign on prominent elevation 200 feet north of spring. Take main road leading southeast, ignoring several trails that lead southwest to a cabin visible half a mile away. The cabin marks the place originally known as Borego Spring, and there is water there also.

39. 8 Road descendsı into bed of San Felipe Creek (dry). Geological Survey sign on north side of road. Continue east, following trails down wash.

41, 8 About here road branches. Various tracks, much scattered, over wide silt-floored wash. Some swing east (left), passing down San Felipe Wash near Barrel Spring; others skirt Borego Mountain, a long low mountain, rising to two peaks on the southwest. Both routes bad but latter is preferable as San Felipe Wash is very sandy. Optional logs are given. 
Left-hand route, by way of Barrel Spring.

41. 8 Swing east (left), down broad wash.

47. 8 Big board sign on white post points north' to Barrel Spring, one-half mile. Tracks lead to the spring but the road is very sandy and hardly passable for automobiles. Continue east down wash. Very bad sand at places. Water poor.

53. 0-54. 0 The tracks leading down. the wash gradually separate and no road at all is left. Turn to the right out of the wash, cross country in best way possible, following a trail if one can be found.

54. 0-55. 0 At this distance one should intersect the main road leading southeast and follow it. He will probably reach the Geological Survey sign at the forks and should continue southeast.
Right-hand route, skirting mountain.

41. 8 Continue southeast, skirting Borego Mountain at a distance of about half a mile from base. There are sand drifts here that get worse close in to the mountain. There is almost no road at all, although tracks appear at places.

46. 0 At about this point the tracks gradually converge into a plain trail and cross a small playa, thence continuing southeast across broken land with sandy washes. The road is bad but mostly plain and passable.

53. 8 A dim trail comes in from north, and a wooden sign points along this trail to Barrel Spring. It is part of the left-hand road. The traveler of that road may or may not find this sign in trying to return to the main road.

54. 0 Geological Survey sign where road reaches old graded county road. A branch road coming in on this grade from the west is the cut-off noted at 27.0. See appendix to this $\log$ (p. 34). Road goes southeast.

55. 2 Road forks. Either follow the old county graded road (left) or take a plain road leading a little more to the south and go by the old town site of San Felipe. The two roads unite about 4 miles away, and right-hand branch is 0.3 mile longer. There is nothing to note on left-hand road. Log of right-hand road is given.

\section{San Felipe branch.}

57. 9 Concrete reservoir and well visible 0.1 mile southwest of road, but water not obtainable. Continue east on main road.

58. 7 Old town site of San Felipe. No one living there in 1918. Several deserted houses. Well, where poor but drinkable water was obtainable in 1918. Continue east, later swinging northeast on main road. Some trails lead south (right) along this part of road.

59. 6 Cabin on south side of the road. The two roads unite. Route continues east over fairly good graded road. Reading on left-hand branch 59.3. Set gage to this and continue northeast. 
59. 3 Go northeast from road junction.

61.5 Cross a large wash up which a branch road leads south, and turn nearly north on east bank of wash.

62.2 Turn east.

62. 3 Harper Well, on north side of road just west of point where road crosses a bridge over wash. Geological Survey sign. Fair water. Continue east.

66. 5 Kane Spring. Poor but drinkable water at pipe leading out of large earthen reservoir. Branch road coming in from north is CoachellaBrawley road. (See p. 18.) Geological survey sign. Continue east, uphill.

66. 6 Narrow pavement begins. Read big red-letter sign giving road rules. Turnouts about every quarter mile.

73. 6 End of pavement. Cross bridge over irrigation ditch and turn southeast along ditch. Water in emergency.

74. 5 Auto Club sign. Go straight east, away from ditch.

76. 4 Go 100 feet south and continue east over good dirt road. Branch roads every half mile or mile serve neighboring ranches but will not be mentioned unless important. Road is adequately signed all the way to Brawley.

79. 0 Good branch road north said to be short cut to Calipatria and Niland. Goodrich and Auto Club signs. Continue east.

80.0 Crossroads. Auto Club and Goodrich signs. Turn south (right).

80.5 Auto Club sign. Branch road continues south. Turn east.

80.8 Cross track of branch line of Inter-California Railway.

81. 0 Auto Club sign. Turn south (right).

81. 5 Westmoreland. Auto Club signs. Corner by store and post office. Water, gasoline, and provisions. Turn east. Branch roads go south and west.

84. 0 Crossroads. Auto Club and Goodrich signs. Highway turns south.

89. 0 Auto Club and Goodrich signs. Turn east (left) down hill.

89.1 Bridge over New River.

89. 5 Palm-lined street (Main Street) leads into Brawley.

90.5 Paved street. Auto Club signs. Continue east to depot. Road south (right) around triangular court leads to Imperial and El Centro.

90. 8 Brawley. Railway crossing at station.

WARNER TO BRAWLEY BY WAY OF CUT-OFF OR COUNTY ROAD.

At the Geological Survey sign at the mouth of The Narrows (27.0) this road leads to the right, down the bed of San Felipe Creek. Only the last 2.3 miles of this road was traveled by the writer, but the approximate route is known and shown on the map. The road was reported by numerous reliable persons as being in very bad condition in 1918, but it may of course be repaired and become more traveled at any time. One should remember in starting over this road that the nearest water is 22 to 25 miles away. However, the total distance is shortened by about 10 miles on this road. The information available may be summarized as follows:

0. 0 Turn right and follow down the dry creek bed at The Narrows (27.0).

2. 0 At about this distance turn to the right, out of the creek bed, and ascend a grade going eastward. The road is probably plainly visible. 
8. 0 Reach summit of a divide and go east, down a long grade that is known to be very sandy.

13. 0 At about this point is a graded highway, badly worn and washed out. This is the county road built by Imperial County to the San Diego County line.

15. 7 (Approximate distance.) A dim road goes south to Hanna Well (see p. 80 ), in a pass in the mountains. Continue east.

18. 0 At about this distance the road reaches the road from Borego at the Geological Survey sign (54.7). Use the main log from this point east (p. 33).

BRAWIEY TO WARNER (91 MILES).

0. 0 Brawley. Railway crossing at station. Go west on Main Street.

0.3 Auto Club signs. Road south (left) around triangular court leads to Imperial and El Centro. Continue west.

1.6 Bridge over New River.

1.8 Auto Club and Goodrich signs. Turn north (right). The region for next 15 miles is well settled, and many branch roads every half mile or mile serve neighboring ranches. Only the important ones will be mentioned. Road is adequately posted.

6. 8 Crossroads. Auto Club and Goodrich signs. Highway turns west (left).

9.3 Westmoreland. Corner by store and post office. Water, gasoline, and provisions. Last supply station for 80 miles.

9. 8 Auto Club sign. Turn west (left).

10. 0 Cross track of branch line of Inter-California Railway.

10. 3 Auto Club sign. Turn north.

10. 8 Crossroads. Auto Club and Goodrich signs. Turn west.

11. 8 Goodrich and Auto Club signs. Good branch road north said to go to Calipatria and Niland. Continue west.

14. 4 Go 100 feet north and continue west.

16. 3 Auto Club sign. Turn northwest along irrigation ditch.

17. 2 Turn west across ditch and start on narrow concrete road. Read big red-letter signboard giving traffic rules. Turnouts provided about every quarter mile.

24. 2 End of paved road.

24. 3 Kane Spring. Geological Survey sign. Road forks beside reservoir. The road northwest goes to Mecca, Coachella, and Los Angeles. (See p. 20.) Take left-hand road leading southwest for Warner. Water at pipe out of reservoir is poor but drinkable. For several miles the road follows a graded bed made when a county road was contemplated and partly built.

28.5 Cross wooden bridge over large wash. Just north of the road is Harper Well.' Fair water. Geological Survey sign.

28. 6 Road turns nearly south.

29. 3 Turn west across large wash. A branch road leads south (left), up this wash. Go straight ahead.

31. 5 Road forks. The graded road lies a little north of a branch that leads through the old town of San Felipe (abandoned 1918). The two roads unite about 4 miles away. As there is nothing to note on the graded road (right) a $\log$ of the left-hand road only is given. The right-hand road is 0.3 mile shorter. 


\section{Left-hand road, by way of San Felipe.}

31. 5 Take left fork. A cabin stands south of the road near this point.

32.4 Pass through old town site of San Felipe. Several unoccupied houses mark the place. There is a well at which poor water was obtainable in 1918. Continue west.

33. 2 A concrete reservoir and a well are visible south of the road 0.1 mile away, but water is not obtainable. Continue northwest on plain road.

35. 6 Continue northwest from fork.

35.9 Return to graded road. Set gage to 35.6 to get distance on the graded road.

36. 1 Geological Survey sign marks road fork. Graded road to left is a cut-off to Warner that was very bad in 1918. See appendix to this log (p. 38). Take right-hand road for Borego Valley.

37. 0 A dim branch road turns northeast (right), away from main road. In 1918 a wooden sign pointing to right-hand fork said: "Borego Valley 18 miles; water 8 miles at Barrel Spring." This road is very bad, however; almost impassable for automobiles. The other road is far from good. Optional logs are given.

Left-hand road.

37. 0 Continue northwest (left) across broken country with sandy washes at places hard to cross.

44. 0 Cross a small playa. At north end of playa the tracks diverge and scatter over a silt-floored wash covered with thin drifts of sand, at places very difficult to cross. There is almost no sign of a road at places. Continue northwest, keeping at a distance of about half a mile from the base of a long low mountain which rises to two peaks on the west. The drift sand is very bad nearer the mountains.

49. 0 At about this point the tracks of the right fork unite and a fairly plain trail leads northwest up the wash. However, it may not be possible to identify this junction.

51. 0 The road climbs a little bank onto a terrace north of the wash. A Geological Survey sign marking this spot should be found easily.
Right-hand road, by way of San Felipe Wash.

37. 0 Take right-hand fork and follow tracks into San Felipe Wash about a mile away. Then continue up wash, which is very sandy.

44. 0 At about this point in the wash a board sign placed on a white post points north to Barrel Spring, half a mile away. The road, however, is probably too sandy for automobiles. Water at Barrel Spring is very undesirable except in case of emergency. Continue west, up the wash, following tracks.

50. 0 At about this point the road unites with the scattered tracks of the left fork and both take a plain course northward up the wash. However, it will probably be impossible to identify this junction.

52.0 (Approximate distance.) The road climbs a little bank onto a terrace north of the wash. A Geological Survey sign marking the spot should be found easily. Set gage to 51.0 if this is noted and follow plain road west. 
51. 0 Readings corrected to Geological Survey sign. Continue west on plain road.

53. 2 Ignore a number of dim tracks leading to the left to a cabin visible on a hill south of the wash. The cabin is at the original Borego Spring, and there is water there, but the road is little used.

54. 0 The road splits around a clump of bushes inclosed by a wire fence. In

- the corral is a cattle trough, and in the center of the bushes is a barrel sunk in the earth in which good water is obtainable. A Geological Survey sign stands on a prominent point 200 feet north. Continue west, the roads uniting around the corral. Next mile is sandy.

56.9 The road intersects a road running north and south. This is on a grassy plain in the center of Borego Valley. A Geological Survey sign stands at the fork. Turn south to reach Warner. The road north leads to houses not far away which were occupied in 1918.

57. 2 House just west of road. Water at flowing artesian well in front yard. Continue south.

58. 0 Pass dim road leading east, and continue south (right).

58. 7 Small cabin on east side of road. Continue south over a high divide.

63. 8 Turning gradually west enter The Narrows, a pass about 300 feet wide with walls 100 to 200 feet high. A Geological Survey sign stands at the entrance. The county road mentioned at 36.1 is supposed to enter here from the east, but no signs of it were visible in 1918. See appendix to this $\log$ (p. 38). Continue west, up the canyon.

64. 8 At about this point the road climbs out of the sandy wash onto a terrace to the south. The Narrows is passed and a considerable little valley exists here.

68.2 The road turns north, crossing the very sandy wash again. One may have difficulty here. Continue west, up a very narrow valley which grows more and more like a canyon.

69. 4 Yaqui Well. Geological Survey sign. There is usually some poor but drinkable water in a little hole 100 feet north of the road.

76. 9 Stuart Spring, or Sumac Spring. Good water at trough 100 feet north of road. Geological Survey sign. The road continues up Grapevine Canyon.

78. 3 Grapevine Spring. A cabin stands on the left of the road in a little valley just beyond a point where the road bends sharply to the right up a hill. Water may be had in the canyon above the house.

78. 8 Grapevine Spring again. The water rises in the canyon about 150 feet south of the road under some willows.

78.9 A branch road leads east (right) to a cabin half. a mile away. It is passable, and water is obtainble but will hardly be needed. Continue up canyon (left).

79.1 Another branch trail leads to cabin mentioned. Continue on plain road up canyon.

79. 3 A faint trail leads east (right). Continue up canyon. Steep grades are encountered here.

80. 6 Summit of divide. Go west, down gently sloping valley.

82. 4 A branch road, usually well traveled, comes in on east from Montezuma. Continue west. There is probably a board sign at this place.

82. 6 Pass through a gate into Warner ranch. "Continue west on road.

82. $7 \mathrm{~A}$ branch road leads north (right) to a mine visible a mile away. Continue west.

84.9 On top of a little granite hill is a Geological Survey sign. A rodd comes in on the southeast from Julian and San Felipe Valley. (Sel p. 38.) 
Turn nearly north, following main road. Some changes have been made recently, and the log may not be entirely correct.

87. 9 A branch road goes east (left). Continue north.

89. 0 Cross the Canada Verde, a little stream, and go west, over a high hill. 90.8 Warner post office. Water, gasoline, supplies, and hotel. Good mountain roads connect with all southern California coast points.

\section{BRAWLEY TO WARNER BY WAY OF CUT-OFF OR COUNTY ROAD.}

At the Geological Survey sign, 36.1 miles from Brawley, this road is noted as going to the left. Only the first 2.3 miles of this road.was traveled by the writer, but the approximate route is known and shown on the map. The road was reported by numerous reliable persons as being practically impassable in 1918, but may of course be repaired or become more traveled at any time, as it is approximately $\mathbf{1 0}$ miles shorter than the route to Warner through Borego Valley. One should remember in starting on this road that the nearest water is at Yaqui Well, 24 miles away. The information available about this road may be summed up as follows:

0. 0 Go west from Geological Survey sign (36.1) where branch road leads northwest to Borego.

2. 3 A rather dim branch road leads south (left), presumably going to Hanna Well, in a pass in the mountains on the south. Continue west on the old county grade, which had been badly washed out by floods.

5. 0 At about this point the county grade ends, as the road was improved only as far as the line between Imperial and San Diego counties. Continue west, up a long grade that is known to be very sandy.

10. 0 . At about this point the summit of the grade is reached and the road goes .west, down a slope toward San Felipe Creek.

16. 0 At approximately this distance the road enters the dry bed of San Felipe Creek and continues west.

18. 0 The road enters The Narrows at the Geological Survey sign mentioned at 63.8. Use main $\log$ (p. 37) west from this point.

\section{WARNER-SAN FELIPE VALLEY-JULIAN.}

A fair mountain road passable for all kinds of vehicles branches from the Warner-Brawley road 5.9 miles from Warner at a fork marked by a Geological Survey signpost and goes south (right) through San Felipe Valley and San Felipe ranch. A short cut through San Felipe Valley leads on southeast to Mason Valley, Vallecito, and the Carrizo country, and the Julian road continues south and west through Banner into Julian.

\section{JULIAN-VALLECITO-CARRIZO-EL CENTRO.}

\section{JULIAN TO EL CENTRO (75 MILES).}

NoTE.-This road is seldom used as a direct route from Julian to El Centro because the longer mountain roads are better. It is important, however, as being the only way of access to Mason Valley, Vallecito, and Carrizo from the west or east. For the last 16.8 miles the road follows the San Diego-Imperial Valley highway.

0.0 Post office at Julian. Go east.

0.2 Road forks. Auto Club and Goodrich signs. Right-hand road goes to Descanso, Jacumba, and El Centro. Take left-hand road for Vallecito and Carrizo. Follow main road east over divide.

1. 0 Summit of Peninsular Range. The road descends Banner grade, a hill over 3 miles long, dropping 1,200 feet. Drive carefully, as road is very narrow. 
4. 4 Bottom of grade. Turn north, across little creek.

4. 8 Banner. Good water. A family living here usually serves meals and may keep gasoline for sale.

5. 0 Road forks. Left-hand road leads through San Felipe Valley, Blair Valley, and down a very sandy box canyon, rejoining right branch at Mason Valley. The right-hand road goes east across the mountains and down Rodriguez Canyon into Mason Valley. In 1917 travelers going east usually took the left-hand road, which is several miles longer, because a hill on the right-hand road was impassable for automobiles. This was improved in 1918, however, and is said to be passable. Inquiry may be made at Banner concerning the roads. Optional logs are given.

Left-hand road, by way of San Felipe Valley.

5. 0 Continue to left, passing down canyon along Banner Creek, which is crossed several times in next mile. Good water in creek.

6. 0 Pass through gate, boundary of San Felipe ranch.

6.5 Roail forks. Left-hand road goes north to ranch house and to Warner. Take righthand road leading northeast.

8. 3 to 8.8 Cross over low ridge which divides San Felipe Valley into upper and lower portions.

10.1 Branch road comes in on north from Warner ranch. Continue east.

10. 7 Pass out of San Felipe ranch, through gate.

11. 2 Windmill on east side of road. Fair water.

12. 1 House on east side of road. Water.

13. 5 Small playa on east side of road.

16. 1 Cross over low ridge dividing San Felipe Valley from Blair Valley. Turn west across Blair Valley.

18. 6 Enter Box Canyon, a narrow and very sandy pass through mountains.

20. 6. Emerge from canyon into Mason Valley.

20.8 Join right-hand road at Geological Survey sign and proceed southẹst, setting gage to 13.8 ,
Right-hand road by way of Rodriguez Canyon.

5. 0 Turn to right, passing up a canyon over steep hills. Follow best traveled road. Road has recently been changed considerably, leaving portions of the old road abandoned.

7.2 Near this point there is a spring on south side of the road; a mining cabin, on north side, usually unoccupied. To the north one looks down upon San Felipe Valley.

8. 3 Summit of divide. The road turns southeast and starts down Rodriguez Canyon.

13. 0 Emerge into Mason Valley.

13.8 Road coming in from north is left-hand branch. Geological Survey sign. Proceed southeast. 
13. 8 Go southeast from signpost.

14. 1 Ranch house on right; well with windmill. Water. Pass through gate and continue southeast. Several trails turn off at places to homesteads, some of which were occupied in 1918. Continue on main road toward lower end of valley.

17. 0 Cross over ridge separating Mason Valley from Vallecito Valley. Descend a very steep hill on the lower (east) side of this ridge.

17.5 Foot of hill. A branch road leads south (right) to a ranch 0.8 mile away. Continue to left.

18. 2 Another branch road leads southwest to ranch mentioned. Continue east. 21.8 Old adobe house on north side of road, ruins of a stage station, called Vallecito. Geological Survey sign. Proceed east.

21. 9 Pass water trough at Vallecito. Good water. Continue east, passing down dry bed of Vallecito Creek, which is very sandy at places.

25. 2 After having turned a little south, around the point of a mountain, a branch road leads south to Agua Caliente Springs, three-fourths mile away. Good water. There may be water at the trough 500 feet east. Turn left unless going to Agua Caliente.

25. 3 Water trough on south side of road. May or may not contain water. Geological Survey sign. Continue east, going down sandy wash after about a mile.

28.3 A branch trail leads down the main wash to Carrizo but is rather bad. Try to keep well to the right (west) and follow a road that climbs out of the wash and goes southeast near the base of the mountains. If one inadvertently continues down the big wash no harm will result, as it leads into the road above Carrizo, about 8 miles away. It is necessary to use this left-hand road to reach a place called Palm Spring. (See p. 82.)

$30.9 \mathrm{~A}$ branch road turns west to an abandoned cabin, about a mile beyond which is a place called The Canebrakes, where a stream of good water runs in a mountain canyon amongst a tangle of cane, etc. To follow main road continue straight (left).

31. 2 Another branch road goes back northwest to cabin. Continue southeast.

34. 2 At about this point the road swings east, down a sandy wash. At 3 or 4 miles to the southwest a clump of green palms is plainly visible on the mountain side. This is Mountain Palms Spring. Good water is found at the place, which is said to be approachable by wagon or automobile.

37. 7 Geological Survey sign on north side of road. A big wash comes in from the northwest, and stray tracks from that direction mark the branch road noted at 28.3. Continue east. - There is very bad sand in the next $1 \frac{1}{2}$ miles, and it may be necessary to deflate tires. (See p. 10.)

39. 2 Carrizo. Geological Survey sign. An adobe house, occupied in 1918, stands on north side of road. Well, on south side, on bank of Carrizo Creek, which flows at the surface for about a mile. Water, either in well or in the creek, is drinkable. Continue east.

40. 0 A road turns to the southwest, going down to the bed of Carrizo Creek. Continue east, later following down dry, sandy floor of creek, several hundred feet wide. Old iron signposts, with two iron plates set at right angles, will be seen nearly every mile. They were once painted signs marking an old stage road but now serve only to assure the traveler that he is on the right track.

46. 0 Turn to the right and ascend a steep hill, out of Carrizo Creek. Proceed southeast. 
50. 0 Geological Survey sign. A branch road goes east (left) into Imperial. (See p. 43.) Continue southeast (right).

51. 6 In this vicinity a number of tracks lead west to a marble quarry at the east end of Carrizo Mountain. Continue southeast, over plain road.

55. 7 Cross a wide and rather sandy wash.

57.2 A branch road goes southeast, but main road turns nearly south (right). Either of these roads leads into $\mathrm{El}$ Centro, but the left-hand one crosses the sandy beach line a mile away.

58. 2 San Diego-El Centro highway. Geological Survey sign. Turn east on paved road.

60.2 Branch road noted at 57.2 joins highway from north. A branch road going south is remains of old highway to San Diego and affords access to Yuha Wells. (See p. 45.) Continue east.

61. 5 Dixieland. Water, gasoline, and supplies. Continue east, through settled country. Branch roads turning off every mile or half mile will not be noted unless important.

65. 7 Turn south 0.1 mile, then east across New River, then north 0.1 mile, then east again. This part not paved. When new bridge is complete this jog will not be made.

66. 2 Start east on pavement after turn just described.

66. 6 Turn northeast, through south edge of Seeley.

67. 6 Turn east again, crossing railway.

73.8. Crossroads. Geological Survey sign. Road north goes to Imperial and Brawley. Turn south, on paved street.

74.1 Turn east on pavement, which is main street. of El Centro.

75. 0 El Centro. At railway station.

\section{EL CENTRO TO JULIAN (75 MILES).}

NoTE.-The road from El Centro to Julian follows the San Diego highway for 16.8 miles west of El Centro, and then turns northwest, passing up the valleys of Carrizo Creek and Vallecito Creek. It is seldom used as a direct road, the longer route by way of Jacumba, Buckman, and Descanso being preferred because it is much better. This route is of importance, however, as a means of access to Carrizo, Vallecito, and Mason valleys from the west or east.

0.0 El Centro. Railway station. Go west on Main Street, which is paved.

0.9 Following pavement, turn north.

1. 2 Crossroads. Geological Survey sign. Road north goes to Imperial and Brawley. Turn west on paved road. Branch roads turn off every half mile or mile through settled country, but only the important ones will be mentioned.

7. 4 Cross railway and turn southwest through south edge of Seeley.

8. 4 Turn straight west again.

8. 8 Turn south 0.1 mile, then west over New River, then north again to line of road from Seeley and continue west. This part is not paved. When the new bridge is completed this jog will not be made.

9. 3 Pavement starts west, on west side of New River.

13. 5 Dixieland, on north side of highway. Water. Last supply station until Julian is reached (61.5 miles).

14. 8 Branch road turns northwest, to Carrizo. Continues west to 16. 8, as this road crosses old beach (very sandy). Another branch road turns south at this point. It is the remains of a former highway to San Diego and affords an approạch to Yuha. (See p. 45.) 
16. 8 Geological Survez sign. Turn north from highway on fair road.

17. 8 Branch road noted at $\mathbf{1 4 . 8}$ comes in from southeast.

19.3 Cross a wide and rather sandy wash. Old iron signposts with two iron plates crossed at right angles and usually bearing no letters whatever are passed about every mile along road to Carrizo. They were once painted signs marking the old stage road, but now serve only to assure the traveler that he is going in the right direction.

23.4 In this vicinity a number of wagon tracks turn west to a marble quarry at the east end of Carrizo Mountain. Ignore them and follow the plain road.

25. 0 Geological Survey sign. A branch road comes in from the east, from Imperial. (See p. 44.) Continue northwest.

28. 8 Descend a steep hill into the bed of Carrizo Creek, which is a sandy flat one-quarter to one-half mile wide. Follow the plainest or easiest track west up this channel. It is very sandy at places. At about 32.0 or 33.0 the road climbs out of the main wash upon a little terrace on the north side and continues west.

35. 0 A road turns to the left, going back to the bed of the creek. Continue west (right), bearing away from creek. Pass over a little clay ridge to a grassy plain about 1 mile wide.

35. 8 Carrizo. Geological Survey sign. Adobe house on north side of road, occupied in 1918. Water may be had at well on bank of creek 50 feet south or in bed of creek, which flows here for about a mile. Water is of fair quality. Continue west. Bad sand in the next mile. Deflate tires if necessary. (See p. 10.)

37. 3 Geological Survey sign on north side of road. A big wash comes from northwest, and tracks turn up this wash at places. It is possible to take this route and reach Vallecito, but the better road continues west, up a large sandy wash.

40.8 At about this point the road swings northwest over a slope covered with coarse sand and gravel, leaving the valley of Carrizo Creek. At 3 or 4 miles southwest and several hundred feet up on the mountain side a clump of green palms is plainly visible. This is Mountain Palms spring. There is good water there, and it is said to be approachable by wagon or automobile.

43. 8 Branch road turns west (left) to an abandoned cabin about a mile away. Continue straight (right).

44. 1 Another branch road turns west to cabin, about a mile west of which is the Canebrakes, a narrow mountain canyon in which there is a considerable stream of good water and a dense growth of cane. To follow main road continue straight (right).

46. 7 A branch trail comes from the southeast at a point where the road descends into a sandy wash. This comes up the wash noted at 37.3. Continue northwest, following tracks up sandy wash.

49. 7 Geological Survey sign. Water trough on south side of road. It may or may not contain water. Good water is obtainable at Agua Caliente Springs, three-fourths mile southwest.

49.8 A branch road goes south to Agua Caliente Springs. To follow main road turn north (right) and go around point of mountain, following up sandy bed of Vallecito Creek. Use plainest tracks.

53.1 Vallecito water trough, Good water. Turn north about 200 feet, then west, following road.

53. 2 gld adobe stage station of Vallecito on north side of road, Geological Survey sign, Continue west, 
56. 8 Branch road leads southwest to Campbell ranch, 0.8 mile away. Continue straight (right).

57. 5 A road leads south to Campbell ranch. Main road turns north, climbing very steep hill over ridge separating Vallecito Valley from Mason Valley. This is a very hard climb.

57. 8 Top of hill. Go down on other side into Mason Valley and continue west over plainest road. A number of trails turn off and several roads lead west, but by keeping the best road through the center of the narrow valley the traveler should have no trouble. The road may beclosed at places by gates. Several homesteaders lived in the valley in 1918.

59. 2 Road forks. Either road leads out of valley, but right-hand branch is shorter and better.

60.9 Ranch, on left side of road. Windmill. Water. Gate across road in 1918. Continue northwest.

61. 2 Road forks. Geological Survey sign. Take left-hand road to Julian. Right-hand road comes from San Felipe Valley but goes up a sandy canyon that is impassable for automobiles going out of Mason Valley, although passable in opposite direction. The road log from here to Julian is only approximately correct. In general the road passes northwest up a narrow mountain gorge called Rodriguez Canyon.

66. 7 Summit of divide. The road bends north, then west around a hill. The valley plainly visible to the north is San Felipe Valley. Follow the main traveled road, which has been changed at several places recently, leaving portions of the former road abandoned.

67. 8 Near this point there is a spring on the south side of the road, and a miners' camp, usually unoccupied on the north side. The rodd passes down some very steep grades.

70. 0 A branch road comes in on east from San Felipe Valley. Go southwest (left).

70.2 Banner. Good water. A family living there usually serves meals and may keep gasoline. Continue soth on main road.

70.6 The road crosses a small creek and turns sharply northwest, up the Banner grade, which is a steady climb, rising 1,200 feet in 3 miles. Drive carefully; as the road is very narrow.

74. 0 Summit of Peninsular Range. Follow main road west into Julian.

75. 0 Julian post office. Water. Hotels and garages. Good roads lead to San Diego, Los Angeles, and nearly all points south or west.

\section{CARRIZO-IMPERIAL.}

\section{CARRIZO TO IMPERIAL (33 MIIES).}

Note.-This log covers a road that branches from the Julian-El Gentro route (see p. 38) at a point 11 miles east of Carrizo and goes nearly due east into the town of Imperial.

0. 0 Carrizo. Water in well on creek bank south of road or in creek bed, poor but drinkable. Geological Survey sign on north side of road. Start east at house of C. A. Strabley.

0.8 Branch road goes southwest toward bed of creek. Continue east, getting down into dry bed of Carrizo Creek; a mile or two east. This is a flat wash, several hundred feet wide. The road is sandy at places.

6. 8 Turn to right, ascending a steep hill out of Carrizo Creek, and go southeast over broken country. 
10. 8 Road forks. Geological Survey sign. Right-hand road leads to El Centro. (See p. 38.) Turn east on left-hand road for Imperial. This road leads over a flat, barren plain and is marked at places by large white posts, usually with no sign whatever on them. It is not a bad road until the old beach is crossed.

19. 6 At about this point the road crosses the old beach, and traveler may have trouble with sand. The sandy spots cover nearly a mile here. Farther on the road passes cleared land that was being made ready for irrigation in 1918.

20.7 Goodrich sign on north side of road. Continue east.

23. 3 Goodrich sign. Continue east. Several houses not far away.

23. 8 West side main canal of Imperial Irrigation District. Goodrich sign just west of this canal, which runs northeast. Cross canal and turn due south beside small irrigation ditch. A branch road goes southwest, along the east side of the canal, to Dixieland.

24. 5 Goodrich sign. Turn east across irrigation ditch. A branch road goes west to Dixieland. The main road for the next 2 miles runs near the north bank of a deep erosion channel known as Salt Creek, or Salt Slough, which may contain a little water.

25.2 A branch road goes south across Salt Creek and turns back west. It is said to afford a way of reaching the San Diego-El Centro highway. Continue east.

25. 8 Goodrich sign. A branch road turns north. Continue east.

26. 6 Sharp crook in the road, which descends the west bank of the New River channel.

26. 8 Bridge across New River. Continue east.

27. 3 Crossroads. Goodrich and Auto Club signs. Road south intersects San Diego-El Centro highway. For Imperial continue east through wellsettled country. There are crossroads every mile or less, but the main road leads due east to Main Street, Imperial.

33. 3 Imperial. Big sign in center of street crossing, about one-fourth mile west of railway station. The paved cross street leads north to Brawley or south to El Centro.

\section{IMPERIAI TO CARRIZO (33 MILES).}

0. 0 Imperial, at intersection with Brawley-El Centro road. Big sign in center of street crossing. Start west on Main Street. The first 6 miles is through a well-settled country, and branch roads turn off every mile or less. Go straight west. The road is well marked by Auto Club and Goodrich signs.

6. 0 Goodrich and Auto Club signs mark the last good crossroads. It is possible to go south to a junction with the El Centro-San Diego highway. Continue west for Carrizo.

6.5 New River. Cross the bridge. After a sharp, short crook in the road go nearly west along north bank of deep channel of Salt Creek, which may contain a little water.

7. 5 Goodrich sign. A branch road leads north. Continue west.

8.1 Branch road goes south across Salt Creek and is said to connect with El Centro-San Diego highway. Continue west.

8. 8 Goodrich sign. A branch road continues west to Dixieland. For Carrizo turn north (right) beside small irrigation ditch.

9.5 West Side main canal of Imperial Irrigation District runs northeast. A road follows canal southwest to Dixieland. For Carrizo turn west (left), 
crossing canal. On west side of canal is a Goodrich sign. For a short distance west the land was being prepared for irrigation in 1918, but beyond that the desert begins.

10.0 Goodrich sign on north side of road. Continue west.

12. 6 Goodrich sign on north side of road. Continue west.

13. 5 At about this point the road crosses the old beach. Bad sand, continuing bad in spots for nearly a mile, then fairly good road. A number of white posts without any signs whatever will be seen along the road.

22.5 Geological Survey sign. Branch road coming in from southeast is El Centro-Julian route. (See p. 41.) Road leads northwest over a somewhat broken country.

26.3 Descend steep hill to flat dry floor of Carrizo Creek, which is several hundred feet wide. Follow the wash westward, using best road available and finally climbing out on a little terrace north of the creek bed. Very sandy at places.

32.5 A branch road turns southwest (left) toward the bed of the creek. Continue west (right), coming upon a small grassy plain not far away.

33. 3 Carrizo. House of C. A. Strabley, on north side of road. Geological Survey sign. Water at well or in bed of creek on south side of road, poor but drinkable.

NotE.-Persons wishing to continue to Vallecito, Mason Valley, or Julian from this point consult the El Centro to Julian log (p. 41).

\section{DIXIELAND TO YUHA AND COYOTE WELLS.}

On the San Diego-Imperial Valley highway, 1.3 miles west of Dixieland, an old macadam road turns, south and takes a somewhat southwesterly course into Coyote, Wells, 13.7 miles away, as measured on this road. The road is an abandoned portion of a former highway that was much used before the construction of the present concrete road. Part of it is surfaced and part dirt road, but most of it was fairly good in 1918 and easily passable for automobiles, although seldom used by anyone.

West of Dixieland 5.8 miles and east of Coyote Wells 7.9 miles, on the old road just described, a faint branch road turns south. It passes the old Yuha Well, drilled for oil, 1.7 miles from the turn, and continues southwest, toward the water hole known as Yuha Wells, for a mile or two more, finally disappearing in a maze of dim wagon tracks and becoming impassable for cars because of sand. It might be possible to reach the Yuha water hole by automobile, but it is hardly worth the effort. It can easily be reached by walking the last half mile.

The "Yuha oil well" is an abandoned drill hole at which there is some camp débris and a 14-inch well casing protruding above the ground. There was water at a depth of about 400 feet in this hole. The Yuha water hole was once a place where teams watered frequently but is now entirely abandoned. Seeps of bitter water in the surrounding arroyos are common, and some can be uncovered by digging with a stick or with the hands, but at present these are unimportant as watering places.

\section{MECCA-BLYTHE-EHRENBERG (MAIN ROUTE).}

MECCA TO BLYTHE (95 MILES).

0. 0 Mecca. Water trough one block south of post office. Start east. Big warning signboard established by Automobile Club of Southern California. Read and heed. 
0.9 Geological Survey and Auto Club signs. Road south goes to Dos Palmas, Niland, etc. (See p. 50.)

3. 2 Pass Auto Club sign.

3.9 Turn northeast. Pass under electric transmission line. Road along electric line is property of Coachella Valley Ice \& Electric Co. but is sometimes used as alternate route to Dos Palmas. (See p. 55.)

6. 0 Enter Shaver Canyon and follow through badlands.

12.1 Shaver Well, on north side of road in canyon. Auto Club signs. Last dependable water supply for 75 miles.

12. 6 Auto Club signs. Take right-hand road. Left-hand road goes to Cottonwood Spring. (See p. 68.)

22. 2 Auto Club sign. Dim trail southeast is old road to Blythe.

29. 0 Auto Club sign. Dim trail goes southeast.

30.6 Auto Club sign. Trail crosses road leading southwest and northeast. On the northeast (left) it goes to abandoned cattle camp half a mile away.

30.9 Trail leads north to the cattle camp.

32.6 Dim trail to southeast (right) probably goes to cattle trough in center of dry lake.

34. 3 Geological Survey sign. Pipe line crossing road comes from small spring in Eagle Mountains to the north and goes to cattle trough in dry lake 1 mile away. In emergency water is usually obtainable at faucet by following pipe line half a mile southwest.

35. 5 Auto Club sign.

38.9 Road fork. Auto Club sign. Left-hand road is old road to Blythe by way of Gruendike Well. Right-hand road does not pass Gruendike. old road is a little longer but more traveled on account of water being obtainable. Mileage by way of Gruendike is adopted, but optional log is given.

Left-hand route.

38. 9 Start northeast.

41. 3 Auto Club sign. Take righthand road. The trail to left goes to Boulder Well. (See p. 50.)

46. 7 Cabin one-fourth mile south, usually unoccupied. No water.

49. 6 Keep left to house and well.

49. 8 Gate at house by Gruendike W e I1. Auto Club signs. Water at faucet north of house.

\section{Right-hand route.}

38. 9 Start east.

41. 3 Geological Survey sign. Road south goes to Granite Mine Well. (See p. 79.)

48. 9 Geological Survey sign. Trail north to Gruendike Well very bad for automobiles.

51.9 Road forks join. Set gage to 53.2 to get mileage by way of Gruendike.

53. 2 Road forks join. Auto Club sign. Go southeast from forks.

58.0 Geological Survey sign. Road west goes to Corn Spring. (See p. 49.)

61. 1 Auto Club sign. Road to left goes to McCoy Spring. (See p. 49.) Very sandy. Trail west is said to go to Corn Spring.

66. 2 Left fork is short cut-off. Continue straight on right fork.

66. 3 Auto Club sign. Turn left. Road southeast to Wiley Well (see p. 49) is probably very bad.

66. 5 Geological Survey and Auto Club signs. Either road equal distance to Blythe, but left-hand road passes wells and right-hand road does not. Optional logs. 
Left-hand route.

66. 5 Keep to left.

70. 6 Hopkins Well, on south side of road. Iron pump.

74. 2 Ford Well. Windmill and cattle camp.

75. 2 Geological Survey and Auto Club signs. Forks join. Go east.
Right-hand route.

66.5 Turn to right.

70.7 Auto Club sign. Road north to

Hopkins Well, one-half mile.

73. 9 Trail north goes to Ford Well, 1 mile. Keep east.

74. 6 Go northeast.

75. 2 Geological Survey and Auto Club signs. Forks join. Go east.

76. 2 Road crosses sand dune ridge. May have trouble here.

77. 0 Auto Club sign.

82. 8 Auto Club sign.

83. 3 Auto Club sign.

84.6 Road skirts point of McCoy Mountains.

86. 6 Patterson ranch. Auto Club sign. Good water.

91. 5 Auto Club sign. Roads branch. Route optional. One goes south onehalf mile and east 2 miles; the other east 2 miles and south one-half mile. Former usually preferred. This brings reading to 94.0.

94. 0 Crossroads at west edge of Blythe. Geological Survey and Auto Club signs. Road south goes to Imperial Valley and Yuma. (See pp. 58-61.) Road north goes to Blythe Junction. (See p. 63.) Road east goes to Blythe and Ehrenberg.

94. 5 Blythe post office. Water. Hotels, garages, and supplies.

BLYTHE TO EHRENBERG (4 MILES).

0.0 Blythe post office. Go east.

2.5 Road leads northeast, then southeast over low swamp through thick jungle.

4. 2 Ehrenberg Ferry over Colorado River.

\section{EHRENBERG TO BLYTHE (4 MILES),}

0.0 Ehrenberg. At west bank of Colorado River.

1. 7 Come out of lowland thicket to straight west road.

4. 2 Blythe post office.

\section{BLYTHE TO MECCA (95 MILES).}

0.0 Blythe post office. Go west.

0.5 Geological Survey and Auto Club signs. Read big warning board. Road north goes to Blythe Junction. (See p. 63.) Road south goes to Yuma and Imperial Valley. (See pp. 58-61.) Road west goes to Mecca. In going to Mecca one may also go one-half mile north and then turn west. Log is for road going west.

2. 5 Auto Club signs. Turn north.

3. 0 Auto Club signs. Turn west.

7.9 Patterson ranch. Auto Club sign. Good water. Last reliable supply of water for 75 miles.

9. 9 Road skirts tip of McCoy Mountains.

11. 2 Auto Club sign.

11. 7 Auto Club sign.

17.5 Auto Club sign. 
18. 3 Road crosses sand-dune ridge. May have trouble here.

19. 3 Geological Survey and Auto Club signs. Road forks. + Both roads lead to Mecca, equal distance, but only right-hand road passes water. Optional logs given.

Left-hand road.

19.9 Turn west.

20.6 Trail north to Ford Well, 1 mile. Keep west.

23. 8 Auto Club sign. Trail north to Hopkins Well, one-half mile.

28. 0 Geological Survey and Auto Club signs. Roads cross.
Right-hand road.

20.3 Ford Well. Windmill and cattle camp.

23. 9 Hopkins Well. Iron pump.

28. 0 Geological Survey and Auto Club signs. Roads cross.

28. 0 At Geological Survey sign. Right-hand road, leading west, is short cutoff, usually sandy. Take left-hand road.

28. 2 Auto Club sign. Turn northwest. Road southeast to Wiley Well is probably very bad. (See p. 49.)

28. 3 Cut-off"comes in from east. Keep straight ahead.

33. 4 Auto Club sign. Trail crosses road. Northeast it leads to McCoy Spring. (See p. 49.) Southwest it leads to Corn Spring, but a better road to Corn Spring turns off farther on. Keep straight ahead.

36. 5 Geological Survey sign. Road west goes to Corn Spring. (See p. 49.) Keep straight road.

41. 3 Road forks. Auto Club signs. Either way to Mecca but right-hand road passes water; left does not. Right-hand mileage by way of Gruendike Well adopted but optional logs given.

Left-hand road.

41. 3 Go west.

44. 3 Geological Survey sign. Trail north to Gruendike Well is very sandy. Keep west.

51.9 Geological Survey sign. Road goes south to Granite Mine Well. (See p. 79.)

54.3 Auto Club sign. Roads join. Set to 55.6 for mileage by way of Gruendike Well.
Right-hand road.

41. 3 Go northwest.

44. 5 Road to left is cut-off. Keep to right, toward house.

44. 7 Gate at Gruendike Well. Water at faucet behind house. Last water for 40 miles.

44. 9 Cut-off comes in from east.

47. 8 Cabin one-fourth of a mile south of road. Usually unoccupied. No water.

53. 2 Auto Club sign. Road northeast goes to Boulder Well. (See p. 50.)

55.6 Auto Club sign. Roads join.

55. 6 Leaving forks the road goes west.

59. 0 Auto Club sign.

60. 2 Geological Survey sign. Pipe line crossing road comes from small spring in Eagle Mountains and leads to cattle trough on dry lake, 1 mile away. In emergency water is usually obtainable at faucet by following pipe line one-half mile southwest.

61. 9 Dim road on left.

63. 6 Road north (right) goes to abandoned cattle camp, one-half mile away. 
63. 9 Auto Club sịnn. Dim crossroad. To north this leads to cattle camp mentioned above.

65. 5 Auto Club sign. Dim road on left.

72. 3 Auto Club sign. Dim road on left.

81. 9 Auto Club sign. Road on right goes to Cottonwood Spring. (See p. 68.)

82. 4 Shaver Well, in canyon on north side of road.

88. 5 Leave Shaver Canyon and reach point overlooking the Salton Sea.

90.6 Pass under electric transmission line and turn due west. Road along electric line is private property of Coachella Valley Ice \& Electric Co.

1 but is sometimes used as route south to Dos Palmas, etc. (See p. 55.)

93.6 Geological Survèy sign. Road south goes to Dos Palmas, Niland, etc. (See p. 50.)

94. 5 Mecca. Water trough one block south of post office.

MOCOY SPRING FROM MECCA-BLYTHE HIGHWAY.

At 61 miles from Mecca on the main road to Blythe (see p. 45) is a dim crossroad, marked by Auto Club and county signposts, which crosses Chuckwalla Valley eastward to McCoy Spring (see p. 66) and westward to Corn Spring. It is little used on the west, as other roads are more convenient. On the east it crosses a wide waste of heavy sand and is said to be practically impassable for automobiles. It is passable for wagons. Its exact course and condition were not ascertained. Both springs are old and reliable watering places.

\section{WILEY WELI FROM MECCA-BLYTHE HIGHWAY.}

From the Mecca-Blythe road, 66.3 miles from Mecca and 28.2 miles from Blythe (p. 45), a dim road goes southeast to Wiley Well. It has not been traveled much recently and is reported as probably impassable for automobiles. The country intervening is known to be very sandy. Good water can be obtained at Wiley Well with rope and bucket, which were provided in 1918.

\section{CORN SPRING FROM MECCA-BLYTHE HIGHWAY.}

At 58 miles east of Mecea and 36.5 miles west of Blythe, on the Meca-Blythe road (p. 45), a branch road marked by a United States Geological Survey sign goes southwest to Corn Spring. The first 8 miles of the road is fair and easily passable, but beyond that the road enters a sandy canyon bed, which at times is very difficult for automobiles. The total distance to Corn Spring from the fork is about 10 miles. There is a little ciénaga in the mountains at Corn Spring, where grass and vegetation and good water are found. A dim wagon road continues west through a pass in the Chuckwalla Mountains to Aztec Well and Mill Camp. This road was said to be nearly impassable in 1918.

Aztec Well is near the southeast corner of T. 6 S., R. 15 E., about 5 miles from Mill Camp and 3 miles from Corn Spring. It is about 15 feet deep, and the water stands about $\mathbf{1 0}$ feet below the surface. It was in good condition in 1917.

MILL CAMP ROADS.

Several dim trails traverse the country between the Orocopia and Chuckwalla mountains, usually passing Mill Camp, an abandoned (1918) mine in the west end of the Chuckwalla Mountains, probably in sec. 5, T. 7 S., R. 15 E. Some of these roads run south from the Hayfields; others go north from the Dos Palmas-Chuckwalla Well country. They are probably passable for any vehicle, 
as this country is rough but not sandy. Mill Camp is said to be a reliable watering place.

\section{BOULDER WELI FROM MECCA-BLYTHE HIGHWAY.}

At 41.3 miles east of Mecca on the road to Blythe by way of Gruendike Well (p. 45) a branch goes northeast to Boulder Well, 7 miles away, in sec. 31, T. 4 S., R. 16 E. The road is passable for automobiles and continues to mining properties in the eastern Eagle Mountains. Another road goes to Palen Well, in sec. 35, T. 4 S., R. 16 E., and Packard Well but is probably impassable for automobiles.

The Boulder Well was a fairly reliable watering place in 1918, but the Palen Well was reported to be dry. The Packard Well contained water in 1918 but was in a very filthy condition.

\section{MECCA-DOS PALMAS-CHUCKWALLA WELI-BLYTHE.}

\section{MECCA TO BLYTHE (103 MILES).}

NoTE.-This road should not be confused with the ocean-to-ocean highway connecting Mecca and Blythe by way of Shaver Well and the Chuckwalla Valley. (See p. 45.) The road here described serves a large territory lying between the Chuckwalla and Chocolate mountains but is little used except by local people and prospectors. It is extremely bad at places and is not recommended as a route for the through traveler.

0. 0 Mecca. Public fountain just north of railway station. Start east.

0.9 Geological Survey sign. Turn south (right). Road leading east is highway to Blythe through Chuckwalla Valley. (See p. 45.)

1: 4 North side of date orchard on Government experimental farm. Turn east beside farm.

1. 7 Corner of date farm. Turn southeast and go over sandy road across barren desert.

2.9 Southern Pacific Railroad. Turn east along north side of track. A little-used branch road comes in down the track.

3.1 Branch road crosses railway to south. Continue east.

4. 7 Branch road crosses railway to south. Continue east. The road is very sandy at places and it may be necessary to deflate tires to 35 or even 30 pounds pressure.

8.7 Leave railway, which turns southeast, and continue in more easterly direction.

8. 8 Geological Survey sign. Branch road turns south along rallway to Mortmar, a station 1 mile away. Take left-hand road leading to Dos Palmas.

9.5 Pass under power line. A branch road following this line is used by linemen, but its use as a public road is discouraged by the company. It is sometimes used as a route to Dos Palmas by going southeast from this fork about 4 miles and then turning away from power line. (See p. 55.) Main road continues east (left), .climbing a steep sandy slope.

12.0 In the next half mile the road crosses the old beach twice, and the sand is very bad. The road then cuts across a point of clay hills.

13. 5 Cross old beach again. Very sandy. Continue east.

15. 8 Dos Palmas. Poor water obtainable by following a path into the center of tule patch and dipping from the open pool. A branch road goes southwest to Salton. An old county signpost marks the fork. Continue east. 
16. 6 Cabin on north side of road. Water. A dim trail turns south to an intersection with the power-line road. Continue east.

17. 2 County signpost. Branch road turns to right, leading to Frink Spring and Niland. (See p. 55.) Continue straight (left).

23. 2 County signpost, on north side of road. Road drops into wide sandy wash here. Many tracks lead 'up this wash, and there is no distinct road. Pick out firmest road and continue northeast up wash.

25. 4 Clemens Well, on south bank of wash in ravine. Good water. Geological Survey sign in the wash 50 feet in front of the well should be visible from most parts of the wash. Continue up wash.

26.9 Cabin and ruins of old Canyon Spring stage station. A county signpost stands near the place. The spring is 1 mile north, up the tributary canyon opposite the house. (See p. 78.) Road to spring very sandy and seldom used. Continue east, up wash, watching for main tracks, which gradually gather into a plain road on south side of wash.

31. 0 County signpost, on north side of road. A branch road goes north up the main wash 100 feet east of this sign but is usually dim. It leads to Mill Camp (p. 49). Main road turns nearly east, up a branch wash, and farther on bends southeast, passing over a much dissected alluvial plain.

34.9 Geological Survey sign. Branch road goes south to Tabaseca Tank, 1 mile away. The road is rough, but passable for automobiles. Water might be had at the tank in emergency. (See p. 85.) Main road continues east.

41. 0 A dim branch road goes to the left, up a big wash. It rejoins the main road 0.8 mile farther on. Take right-hand road, passing to the south, over a low granite hill.

41. 8 Branch road reenters in big sandy wash. Follow the plainest road southeast, crossing numerous sandy washes.

44. 7 Geological Survey sign. Branch roads go north and south. Water $3 \frac{1}{2}$ miles north (on left) at Gulliday Well. The road south goes to Niland but is very bad. Continue east ( straight).

45. 9 Another branch road leads north (left) to Gulliday Well. Continue east.

48. 0 Summit of divide between drainage basins of Salton Sea and Colorado River. A very extensive view is obtainable from this point. Road continues east, then southeast, passing down a wide sandy wash.

56. 0 At about this point the road emerges from the wash and turns sharply north.

56. 8 County signpost 100 yards south of Chuckwalla Well, which may be reached by walking north to opening in a little wash coming out of the hills to the north. Water of fair quality. Turn southeast for Blythe.

57. 7 Dim trail turning south (right) is said to lead to Salvation Spring. It is impassable by automobile. Continue on main road (left), which leads east, down a rather sandy wash.

64. 0 to 67.0 Road in this stretch passes down a wash through a gap between the Chuckwalla Mountains and the Black Hills. Many little lava hills along the way. The road then emerges upon a hard, smooth, gravel plain and goes northeast.

70.8 A plain but little-traveled road leads south to Salvation Spring and Niland. (See p. 57.) - Continue northeast.

72. 0 Pass ruins of an old stone house, the Mule Springs stage station, on north side of road. A well once existed 100 feet north in the wash, but there is no water at the place now. 
77. 6 Faint trail leads east. It is a cut-off avoiding Wiley Well. Take main road (left).

77. 8 Wiley Well. Good water obtainable with rope and bucket, which were provided in 1918. County signpost at well. Go east on main road, which is sandy, passing over a high and much dissected alluvial plateau lying on the south flank of the Mule Mountains.

81. 0 Summit of pass through south end of Mule Mountains. Road drops down a canyon to east, very rough and rocky.

82. 0 Climb out of canyon and go east across small level plain.

83. 8 Pass down a very sandy wash through some scattered granite hills, the south end of the Mule Mountains, emerging on sandy plain above the low Colorado River valley.

85. 0 Branch road goes northwest to mine visible on side of mountains. Continue east.

86. 6 Edge of terrace overlooking Palo Verde Valley.

86.9 Foot of terrace. County signpost. Go east over mesquitecovered lowland.

87. 3 Irrigation ditch, go east on north side of it.

88. 8 Blythe-Glamis road. (See p. 58.) Geological Survey sign. Turn north (left) to Blythe. Water and supplies may be obtained at Rannells, 0.2 mile south of this corner.

91. 4 Road turns northeast, across mesquite thicket. The soil is a soft silt that wears quickly into deep ruts, so that innumerable trails have been made which cross and recross in a bewildering manner. All of them eventually lead to Blythe. Use best and plainest tracks. Numerous signposts along the way.

92.8 Cross over fill in channel of bayou full of clear water.

95. 6. Branch road leads north. Turn straight east on good road through cultivated land.

96. 6 Neighbor School. Continue east.

97. 6 Auto Club sign. Turn north (left).

98. 6 Auto Club sign. Turn east (right).

100. 6 Auto Club sign. Turn north (left).

102.1 Crossroads at west edge of Blythe. Geological Survey sign. Road west goes to Mecca (p. 47). Road north goes to Blythe Junction (p. 63). Turn east into Blythe.

102. 6 Blythe. At post office, two blocks east of railway crossing.

\section{BLYTHE TO MECCA (103 MILES).}

Note.-This road should not be confused with the ocean-to-ocean highway connecting Blythe and Mecca by way of Chuckwalla Valley and Shaver Well. (See p. 47.) The road here described serves a large territory lying between Chuckwalla and Chocolate mountains but is little used except by local people and by prospectors. It is extremely bad at places and is not recommended as a route for through travelers.

0. 0 Blythe. Post office, two blocks east of railway crossing. Start west.

0. 5 Crossroads. Geological Survey sign. Road north goes to Blythe Junction (p. 63). Road west is main road to Mecca (p. 47). Turn south for road to Mecca by way of Chuckwalla Well and Dos Palmas.

2. 0 Auto Club sign. Turn west (right).

4. 0 Auto Club sign. Turn south (left).

5. 0 Auto Club sign. Turn west (right). 
6. 0 Neighbor School. Continuè west.

7.0 Branch road leads north. Turn southwest across uncultivated desert, mostly mesquite thicket. The soil is soft silt which quickly wears into deep ruts, and hence roads wind in every direction in a bewildering way. Pick out the best and plainest. All lead to right place. Auto Club signs are numerous.

9.8 Cross over fill in channel of slough of fresh water.

11. 2 Road turns straight south and passes by some cultivated land.

13. 8 Geological Survey sign. The road south continues to Glamis and Yuma. Rannells, 0.2 mile south of this corner, is last supply station for 89 miles. For Mecca turn to the right, crossing bridge and going west on north side of irrigation ditch.

15.3 End of irrigation ditch. Continue west over mesquite-covered lowland.

15. 7 County sign, on north side of road. Go west, uphill. Very sandy.

16. 0 Edge of terrace overlooking valley to the east. Continue west over sandy plain.

17.6 Branch road turns to right; leading to a mine visible on mountain side. Continue straight (left).

18.8 Pass up a very sandy wash through low granite hills at south end of Mule.Mountains. Emerge on a small plain and continue west.

20.6 Descend into canyon and go west. Very rough and rocky.

21. 6 Summit of pass in Mule Mountains. Go west, descending long alluvial slope, much dissected, to sandy plain.

24. 6 Dim trail turns left. This is a cut-off avoiding Wiley Well. Take main road (right).

24. 8 Wiley Well. Good water obtainable with rope and bucket, which were provided in 1918. County sign by well. Turn slightly south, then west across some sandy washes and then ascend long gravel slope going southwest.

30. 6 Ruins of old stone house-Mule Springs stage station-on north side of road. A well once existed 100 feet north of this place, but ro water is now obtainable.

31. 8 A plain but little traveled road leads south to Salvation Spring and Niland. (See p. 57.) Continue southwest (right) on main road.

39. 0 to 42.0 Road in this stretch passes up a sandy wash, through a gap between the Chuckwalla Mountains and the Black Hills. Many little lava-capped hills along the way.

44.9 Dim trail leading south (left) is said to go to Salvation Spring. It is impassable by automobile. Continue west.

45. 8 County sign 100 yards south of Chuckwalla Well. Fair water may be had by walking north to opening of wash leading out of hills. Turn' sharply south for Mecca.

46. 6 Road curves westward into a wide sandy wash and follows it for several miles.

54. 6 Summit of divide between drainage basins of Colorado River and Salton Sea. A very extensive view is obtainable here. Continue west over an alluvial plateau badly dissected by washes, many of which are sandy and difficult to cross.

56. 7 A dim branch road leads north (right). It is said to go to Gulliday Well $3 \frac{1}{2}$ miles north, but another road is available a mile farther on.

57. 9 Geological Survey sign. A branch road leads north to Gulliday Well, $3 \frac{1}{2}$ miles. It is passable and water could be had if needed. Another 
branch road leads south to Niland but is very bad. (See p. 26.) Continue west.

60.8 A faint branch road continues west (right), down a sandy wash, and presumably rejoins the main road 0.8 mile west. Keep to the left, climbing out of wash and passing over a low granite hill.

61. 6 Branch road rejoins main road. Continue west.

67. 7 Geological Survey sign. A branch road, rough but passable, goes south to Tabaseca Tank, 1 mile dway. Water in emergency. Continue west.

71. 6 County sign on north side. Road enters wide sandy wash and goes southwest. A branch road follows up this wash northeast to Mill Camp. (See p. 49.) Follow main road southwest. The tracks gradually spread out all over the width of the wash but any path that is good may be used.

75. 7 Cabin and ruins of old Canyon Spring stage station, on south side of road. County sign. The spring is 1 mile north, up a branch canyon opposite the cabin, but is hard to reach and an unsatisfactory waterhole. Continue west. Good water at Clemens Well is only $1 \frac{1}{2}$ miles away.

77. 2 Clemens Well, on south side of wash. Good water. A Geological Survey sign 50 feet in front of well should be visible from most parts of wash. Continue down wash, keeping near north wall.

79. 4 County sign on north side. Road climbs out of wash. Continue west.

85. 4 County sign. Branch road turn southeast to Frink Spring and Niland. (See p. 55.) Continue west.

86. 0 Cabin on north side of road. Water. A dim trail leads south to various roads going to Niland. Continue west.

86. 8 Dos Palmas. County sign. Poor water is obtainable by following path through tules to pool. A branch, road leads southwest (left) to Salton. Continue west (right) for Mecca. Occasionally persons go southwest on the Salton road to the power line (see p. 55) and turn north along power line to Mecca.

89. 0 Cross old beach. Deep sand may cause trouble. Deflate tires to 35 pounds if necessary. After crossing the beach the road passes through clay hills and crosses beach twice more. It then descends a long, sandy slope to west.

93. 1 Power line. A branch road following this line is used by linemen, but its use as a public road is discouraged by the company. Nevertheless, persons sometimes use it going south to. Niland or north to Mecca. (See p. 55.)

93. 8 Geological Survey sign about 0.1 mile east of Southern Paciflc Railroad. A branch road goes south along railway to Mortmere, a station 1 mile away. Continue west to Mecca.

93.9 Reach railway and follow west along north side of track. Parts of the road are very sandy.

97. 9 Branch road crosses railway to south. Continue west.

99. 5 Branch road crosses railway to south. Continue west.

99. 7 Turn northwest, away from railway. A dim road continues along railway into Mecca, but is little used.

100.9 Corner of date garden at Government experimental farm. Go west, along north side of farm.

101. 2 Turn north, away from date farm. 
101. 7 Main Mecca-Blythe road. (See p. 45.) Geological Survey sign. Turn west.

102. 6 Mecca. Water fountain just north of railway station, 1 block south of post office. Water, gasoline, supplies, and hotel.

MECCA TO NILAND, ON EAST SIDE OF SALTON SEA.

\section{GENERAL OUTLINE.}

East of the Salton Sea a number of very bad roads go southeast to Dos Palmas, Frink Spring, Niland, and intermediate points along the Southern Pacific Railroad. Natural difficulties such as deep arroyos and bad sand, combined with little travel, are the worst features of the roads, and by all but a few local residents they are considered practically impassable for automobile. The writer has traveled no one route consecutively all the way, but parts of all of them. The combinations of cross trails used in endeavoring to find a passable way through this uninhabited area are a source of much perplexity to travelers unacquainted with the country.

There is a legitimate desire on the part of the citizens at Mecca and Niland to have the road improved, and undoubtedly if it were easily passable it would be valuable to travelers going from Los Angeles to Yuma, as it is about 20 miles shorter than the present road around the west side of the Salton Sea.

The distance by various routes from Mecca to Niland is 40 to 45 miles. No supplies are obtainable between these points, but water can be had at any of the five or six stations along the Southern Pacific Railroad and also at Dos Palmas and Frink Spring. The latter places, however, furnish very poor drinking water.

There are three general routes available, which are described in turn. They are (1) the road along the railway, (2) the road along the power line, and (3) the road passing through Dos Palmas and Frink Spring.

\section{ROAD ALONG SOUTHERN PACIFIC RAILROAD.}

A road follows the Southern Pacific Railroad nearly if not quite all the way between Mecea and Niland. So far as known it is never used by automobiles between Mortmar and Wister, but it is passable from Mecca to Mortmar. From Wister a very good road leads south and east along section lines to Niland. Automobilists from Niland are advised to use this road as far as Wister (9.3 miles from Niland) and to cross the railway and turn east to the power line or to other roads at a point $1 \frac{1}{2}$ miles northwest of Wister (10.7 miles from Niland). In 1917 there was no crossing provided at the railway, and it was difficult for automobiles to get over.

\section{ROAD ALONG POWER LINE.}

Along the electric transmission line of the Coachella Valley Ice \& Electric Co., which runs from San Bernardino to Imperial Valley, there is a road used by linemen and company officials. This road is private property of the company, which has posted signs discouraging its use by the public. However, it is used considerably by local residents and is easily followed. It crosses many deep gullies and is exceedingly rough but nevertheless is probably the safest of the possible roads.

\section{ROAD THROUGH DOS PALMAS AND FRINK SPRING.}

Two miles east of Dos Palmas, on the road from Mecca to Blythe by way of Dos Palmas, a road turns southeast (right) to Niland. The first 6 or 8 miles 
of this is across bad sand but could probably be traveled by any automobile which succeeded in getting to Dos Palmas. The distance from Dos Palmas to Frink Spring is about 12 miles and that from Frink Spring to Niland by way of Wister is 16 miles. This makes the total distance between Mecca and Niland 44 miles. By using the road southeast of Frink Spring to its junction with the power-line road, 8 miles away, and then following the power line, the distance into Niland is reduced to only 13 miles. This road follows an abandoned railway grade for a long disance and is in places fairly good.

\section{NILAND TO GULIIDAY WELI.}

[Distances' are approximate from Niland.]

GENERAL OUTIINE.

North and slightly east of Niland is a great, conspicuous embayment in the southern wall of the Chocolate Mountains, known as Iris Pass. This affords a natural roadway through the range and has occasionally been used by stages, freighters from mines to the north of Niland, and prospectors. The road is at present almost unused and is really no road at all, but a very bad, rough, sandy passage by which wagons and even automobiles occasionally enter the area to which it offers access. There are no habitations and no watering pplaces along the way, 'and it is so little traveled that the dim tracks observed may be a year old and usually wander about in widely divergent directions. As an automobile road this is practically impassable, particularly going north, which is a continuous ascent. Only an approximate $\log$ and general description of the area can be given.

\section{NILAND To ChoColate MOUNTAINS (12.5 MILES).}

The road starts at the Geological Survey sign on the corner by the post office at Niland and goes straight north across the railway $(0.1)$ at the station, turning to right for a little way at a road fork $(0.2)$ where a branch road goes northwest to Frink Spring, Dos Palmas, and other places. The road here considered goes north under a transmission line ( 0.5 approximate) to the Highline canal of the Imperial Irrigation District (1.5). Crossing a wooden bridge at the canal, a fairly plain trail goes northeast up a sandy wash over the unimproved desert. Gradually the wash deepens until it is an arroyo, 200 to 300 feet wide, with vertical walls cut in soft clay and sandstones and ramified by extensive tributary arroyos.

At about 4.0 miles a number of tracks go east (right), up one of the tributary arroyos, and are said to continue to a gap in the Chocolate Range known as Surveyor Pass, which is less prominent than Iris Pass, farthèr east. To reach Iris Pass continue (left) up the main arroyo, where guiding tracks will usually be seen, toward the big and unmistakable gap ahead.

The road is rough, gravelly, and sandy; it climbs over little arroyos and gullies into others similar and more misleading; in short it is very bad, being scarcely a road at all, until finally the tracks gather together again into a fairly. well defined trail at the south edge of the Chocolate Range (12.5, approximate).

IRIS PASS.

At its entrance Iris Pass is 2 or 3 miles wide, and the road is near the west wall. A wide sandy wash flanked on the west by steep mountains and bordered on the east by low hills that gradually rise into mountains, is fol- 
lowed northward. At $\mathbf{1 5 . 5}$ miles, the pass narrows to a canyon from $\mathbf{1 0 0}$ to 300 feet wide, and beyond this point it increases in narrowness and steepness. The whole road through this part of the pass is very sandy. Automobile tires will probably have to be deflated in going up. The road finally ascends an exceedingly steep but firm hill and emerges on a plateau at the north side of the Chocolate Mountains (20.0), from which a magnificent view is obtainable.

MECCA-BLYTHE ROAD CROSSING.

From the north edge of the Chocolate Mountains the road is very good and descends a gentle slope northward over rolling gravelly hills until at about 22.0 miles from Niland it reaches a crossroad that leads west to Dos Palmas and Mecca, east to Chuckwalla Well and Blythe. There is a Geological Survey sign at the crossing. This gives the distance south to Niland as 25 miles, that distance not having been accurately known when the sign was established and an error in favor of greater length .being preferred to the danger of giving too little:

\section{GULLIDAY WELI.}

The portion of the road from the crossing northward to Gulliday Well is little traveled except by prospectors interested in the Chuckwalla Mountains. It is about $3 \frac{1}{2}$ miles from the Geological Survey sign to the well, abd the road is rather stony and rough, the last half mile especially so. It is possible to approach within about 100 feet of the well by automobile, and at this point the road ends beside a little arroyo near the base of the Chuckwalla Mountains.

Gulliday Well is a shallow hole in granite beside this arroyo and contains good water at all times unless polluted by surface trash. The well is used chiefiy by prospectors and miners in near-by territory.

\section{SURVEYORS PASS ROAD.}

The Surveyors Pass road is only a dim wagon trail that leaves the NilandGulliday Well road 4 miles north of Niland and goes nearly east, farther on turning northeast toward a noticeable pass in the Chocolate Range east of Iris Pass. The road was used about 1912 or 1913 by a party of land surveyors who camped somewhere in the pass and from whom focal residents have. attached the name given. The road is probably too bad for automobile travel and is said not to lead entirely through the mountains. It is of interest chiefly to prospectors. Springs or water holes are not certainly known to exist in the mountains but may possibly be found there. The road extends 16 or 18 miles from Niland.

\section{NILAND-SALVATION PASS-BLYTHE.}

About 8 miles east of Niland, on the road to Yuma, a number of trails turn off to the left toward the Chocolate Mountains. They unite and go through a break in the mountains known as Salvation Pass. The road then continues northeast to a junction with the road between Mecca and Blythe by way of Dos Palmas. This junction is 7 miles west of Wiley Well. The road was not traversed, but its location as shown on this map is fairly accurate, especially in the mountains, having been taken from a recent township survey. The road is very bad and difficult to travel, by automobiles, being both rough and sandy. Travelers unacquainted with the country are not advised to attempt it. The only water along the road is at Salvation Spring or the Peg Leg Well, and 
these places are off the road and may be hard to find. The road shortens the distance between Niland and Blythe very materially, and so there is some talk of improving it. At present it is seldom used.

Salvation Spring is near the center of sec. 36, T. 10 S., R. 16 E., and is about a mile southeast of the main road in a side canyon. The Salvation Spring Pass follows a deep canyon that originates as a dry wash in an elevated plain east of the range and cuts directly across the main chain southwest. Usually tracks or a board sign or something else is visible, indicating the turnout to Salvation Spring on the east. There is said to be only a small seep of water at the spring, and it may be necessary to dig a little in the sand of the wash to uncover it. Somewhere near the spring is a miner's cabin, occasionally occupied by prospectors, and trails connect the place with the Peg Leg mine (abandoned in 1918) and well, a mile or two away.

In the eastern part of the Salvation Spring Pass through the Chocolate Mountains a trail turns southeast up a tributary arroyo to the Peg Leg Well and mine. The road was not traversed nor the well visited by the writer and information about it was obtained from local residents and from recently surveyed township plats. The mine is near the southwest corner of T. 10 S., R. 17 E., a mile or two east of Salvation Spring, and about 2 miles from the NilandBlythe road through the pass. It is not definitely known whether the well is at the mine or farther down the wash nearer the main road. It is described as $\mathbf{1 0 0}$ feet deep, 60 feet to water, and equipped with windlass and bucket. A board sign generally indicates the turnout. This mine should not be confused with the mythical mine of Peg Leg Smith.

\section{BLYTHE-GLAMIS ROUTE TO YUMA AND IMPERIAL VALLEY.}

\section{BLYTHE TO GLAMTS (59 MILES).}

0. 0 Blythe. Post office, two blocks east of railway crossing. Start west.

0.5 Crossroads. Geological Survey sign. Road north goes to Blythe Junction (p. 63). Road west goes to Mecca (p. 47). Turn south for Glamis.

2. 0 Auto Club sign. Turn west (right).

4. 0 Auto Club sign. Turn south (left).

5. 0 Auto Club sign. Turn west (right).

6. 0 Neighbor School. Continue west.

7. 0 Branch road leads north. Turn southwest across uncultivated desert, mostly a mesquite thicket. The soil is soft silt which quickly wears into deep ruts, and the roads wind everywhere in a bewildering way. Pick out the best and plainest. All lead to right place. Auto Club signs are numerous.

9. 8 Geological Survey sign. Cross over fill in slough of fresh water.

11. 2 Road turns straight south and passes cultivated land.

13. 8 Branch road crosses irrigation ditch and goes west to Wiley Well, Dos Palmas, etc. (See p. 52.) Continue south.

14. 0 Rannells. Store and post office (combined). Water and gasoline. Continue south. The road at places passes through mesquite thickets. Numerous trails lead away, but main road is easily distinguished and well marked with signs.

17.1 Auto Club sign. Branch road goes east. Continue south.

18. 5 Road emerges into open space and turns due south into Palo Verde.

18. 7 Palo Verde. Store and post office (combined). Water and gasoline. Continue south.

18. 8 Palo Verde School. Turn west.

19. 2 Auto Club sign. Branch road continues west. Turn south. 
21.8 Auto Club sign. Branch road goes east to Cibola Landing.

22. 3 Ascend out of valley to terrace overlooking valley.

23.' 1 Road forks. Mileage is given over left-hand road. The straight road is 0.4 mile shorter but crosses two bad hills.

23. 8 Auto Club sign. Roads unite and continue south.

26. 0 Enter canyon and follow it south through pass in Palo Verde Mountains.

27. 8 Summit of pass. Road continues south down another canyon.

30. 0 Emerge from canyon upon large gravel-strewn plain. The road from this point to Glamis is over hard gravel plain most of the way.

30. 4 Auto Club sign.

30.9 Road forks. The two branches run parallel to each other, about half a mile apart, and reunite 5.3 miles away. There is nothing to note on right-hand (west) branch, so only log of left-hand (east) branch is given. This fork is in a large wash called the Arroyo Seco. Numerous other big washes cross the road in the next 5 miles but none are difficult to pass.

34.9 Auto Club sign. Plain road turning east leads to a manganese mine 5 miles southeast. Continue south.

36. 2 Auto Club sign. Branches noted at 30.9 reunite. Continue south.

37. 3 Smith Well. Water of fair quality obtainable by windlass. A mining camp was being started here in 1918, and a mill was being erected on the hillside east of road opposite well. Continue south.

37. 4 Plain road leads west to Paymaster mine, 3 miles away. Continue south (left).

41. 1 Road forks. Both roads lead to Glamis. Left-hand road probably preferable. Right-hand road leads over rolling hills and down a canyon pass, rejoining left-hand road 9.2 miles away (50.3 on right-hand road). Auto Club sign points to right-hand road for Glamis but need not be heeded. Log is for left-hand road.

44. 2 Geological Survey sign. Plain road going south (left) leads to Yuma by way of Tumco. Persons going to Yuma on this road should turn to the left here and use the $\log$ of the Tumco cut-off (p. 61). Take righthand (west) road for Glamis.

47.1 Dim trail leads south. Continue southwest.

49. 3 Branch road noted at 41.1 rejoins. Go south.

53. 3 Pass through group of low lava hills.

58. 3 Auto Club sign. Branch road leads southeast to Yuma. Continue southwest for Glamis.

58. 5 Glamis railway station. Water is obtainable from railway cistern. Charge of 5 cents a head for stock. Gasoline and meals can be had at store.

\section{GLAMIS TO BLYTHE (59 MILES).}

0.0 Glamis railway station. Start northeast on main road, away from railway. Road runs over hard gravel plain and is generally good for nearly 35 miles.

0.2 Road forks. Auto Club signs. Right-hand road turns east to Yuma. Continue northeast for Blythe.

5. 2 Pass through a group of low lava hills.

9. 2 Road forks. West (left) branch goes up sandy canyon and over a rolling plateau and rejoins the east fork (at 18.4 measured on west road). Log is for east (right) branch, which is a mile shorter and is more traveled.

$157138^{\circ}-20-5$ 
11.4 Dim trail leads south. Continue northeast over rolling plain covered with low lava hills.

14. 3 Geological Survey sign. Branch road enters from south. This road comes from Yuma by way of Tumco mining camp. (See p. 61.)

17. 4 West branch noted at 9.2 rejoins. Go north.

21.1. Plain road leads west to Paymaster mine, 3 miles away. Continue north.

21. 2 Smith Well. A mining camp was being established here in 1918, and a mill was being erected on the hillside east of the road, opposite the well. Water of fair quality was obtainable by a windlass. Continue north.

22.3 Road forks. The two branches run nearly parallel and about half a mile apart, rejoining 5.3 miles away. Distance equal. Only $\log$ of east (right) branch is given. Auto Club sign points to Blythe along east branch.

23. 6 Auto Club sign. Plain road turning east leads to a manganese mine 5 miles southeast. Main road continues north. Several large washes cross the road in the next few miles, but none are difficult to pass.

27. 2 Enter Arroyo Seco, the largest wash of all.

27. 6 West branch noted at 22.3 rejoins. Go north.

28. 1 Auto Club sign.

28.5. Road enters winding canyon and follows it up northward, through pass in Palo Verde Mountains.

30. 7 Summit of pass. Road goes down another canyon, leading north.

34. 7 Road forks. Both roads lead to Blythe. The left-hand road, going straight ahead, is 0.4 mile shorter but has two bad hills. Most travelers take right-hand road, which turns east. Log is for righthand road.

35. 4 Branch road noted at 34.7 rejoins. Continue north.

36. 2 Descend from terrace into Palo Verde Valley, a low, flat plain along Colorado River.

36. 7 Auto Club sign. Branch road goes east to Cibola Landing. Continue north. Numerous trails leave the main road in this region, which is largely a mesquite swamp, but the main road is easy to follow and well marked with signs.

39. 3 Auto Club sign. Branch road goes west. Turn east (right).

39. 7 Palo Verde School. Turn north to town.

39. 8 Palo Verde. Store and post office (combined). Water and gasoline. Continue north for Blythe.

40. 0 Road turns sharply northeast through dense thicket of mesquite. Numerous trails turn to either side, but main road is plain and well marked with signs.

41. 4 Auto Club sign. Branch road goes southeast. Continue north.

44.5 Rannells. Store and post office (combined). Water and gasoline. Continue north for Blythe.

44. 7 Geological Survey sign. Branch road that turns west across irrigation ditch leads to Wiley Well, Dos Palmas, etc. (See p. 52.) Continue north.

47. 3 Road turns northeast across mesquite thicket. The soil is a soft silt that wears quickly into deep ruts, so that innumerable trails have been made which cross and recross in a bewildering manner. All of them eventually lead to Blythe. Use best and plainest tracks. Numerous signposts along the way.

48. 7 Cross over fill in slough full of clear water. 
51.5 Branch road leads north. Turn straight east over good road through cultivated land.

52. 5 Neighbor School. Continue east.

53. 5 Auto Club sign. Turn north (left).

54. 5 Auto Club sign. Turn east (right).

56. 5 Auto Club - sign. Turn north (left).

58. 0 Crossroads at west edge of Blythe. Geological Survey sign. Road west goes to Mecca (p. 47). Road north goes to Blythe Junction (p. 63). Turn east (right) into Blythe.

58. 5 Blythe. Post office two blocks east of railway crossing. Water. Hotels, garages, and supplies.

\section{BLYTHE-YUMA ROUTE BY WAY OF' TUMCO.}

\section{GENERAL STATEMENT.}

Most persons making the trip between Blythe and Yuma go by way of Glamis, using the Blythe-Glamis road (p. 58) and the Niland-Yuma road (p. 23). The road here given leaves the Blythe-Glamis road 44.2 miles from Blythe and joins the Niland-Yuma road 11 miles from Yuma, effecting a saving of about 15 miles in the total distance as ordinarily traveled. This road is generally known as the Tumco road or the Tumco cut-off, because it passes near the deserted mining camp known as Tumco, formerly called Hedges. As it is one of the best desert roads found anywhere, it deserves a more general use than it has at present.

\section{BLYTHE TO YUMA (83 MILES).}

See page 58 for the road from Blythe to the Geological Survey sign, 44.2 miles from Blythe and 7 miles south of the Smith Well, where the Tumco cut-off branches from the road to Glamis.

44. 2 Take left-hand road. Proceed south down a wide wash in which ironwood grows abundantly and finally emerge after about 6 miles on a smooth gravelly plain. There are few landmarks, but the road is excellent.

61. 2 A branch road leads north to a place on Colorado River known as Hoges Ferry. There was a board sign at the fork in 1918. Continue on the main road, which leads southeast.

62. 7 The road crosses a wash in the foot of the mountains north of Ogilby. A branch road leads up the wash to the deserted city of Tumco, which is plainly seen about a half mile away. Continue southeast without passing through the town. Usually no one lives at the place, and there is no water there.

63. 2 Some branch roads turn to the right, away from the mountains, and lead to Ogilby. There are innumerable tracks leading over the desert in the next 3 or 4 miles, but it should not be difficult to follow the main road southeast near the base of the mountains but not actually within them. The traveler need not fear getting lost, as it is impossible to go far to the left into the mountains, and all roads turning to the right (south or west) lead to Ogilby, on the Southern Pacific Railroad, from which it is possible to go to Yuma.

68. 0 Plain road coming from the west from Ogilby. Auto Club sign at the fork. Continue nearly east toward Yuma. 
69. 7 A branch road leads southeast (right) to the railway. Take the lefthand road.

71. 7 The road joins the Niland-Yuma road, which enters from the south and continues southeast. Geological Survey sign at the fork.

74. 8 Descend into a sandy wash 50 feet or more in depth across the river terrace and follow it for about $1 \frac{1}{2}$ miles, emerging on the lowland known as Yuma Valley.

76. 3 Turn east (left) along irrigation ditch. A branch road goes southwest.

77. 2 Turn south (right).

77. 7 Touch railway and turn east. A branch road goes south across the railway.

79. 9 Cross a bridge over a very large canal and just east of it a bridge over a smaller canal.

80. 7 Crossroads. Geological Survey sign. Turn south (right) to Yuma.

82. 2 Cross a railway and turn east up a hill. Yuma Indian School on left.

82.3 Reach bridge over Colorado River. Cross and follow principal streets into Yuma.

82. 7 Yuma. At post office or railway station.

\section{YUMA TO BLYTHE (88 MILES).}

0. 0 Yuma post office or railway station. Follow the principal streets to the bridge over Colorado River.

0.3 Bridge over Colorado River. Cross and go west downhill by Yuma Indian School.

0.5 A branch road leads to the left and offers a possible route to Imperial Valley points. Continue straight ahead, crossing a railway track and turning north.

2. 0 Crossroads. Geological Survey sign. Turn west (left) for Blythe.

2. 7 Cross a bridge over a large canal, and a little farther on a bridge over one much larger. Continue west.

5. 0 Road reaches railway and turns north (right), away from it. A branch road goes south across the railway.

5.5 Turn west (left).

6. 4 Turn north (right) and go about $1 \frac{1}{2}$ miles up a deep sandy wash to terrace above. A branch road leads southwest (left) at the turn.

11. 0 Road forks. Geological Survey sign. The road going south, (left) goes to Ogilby, Glamis, and Imperial Valley. To take Tumco cut-off to Blythe continue northwest.

13. 0 A branch road enters from the southeast (left). Continue west.

14. 7 Auto Club sign. A plain road leads to the west (left) directly into Ogilby. Take right-hand fork. There are tracks and trails leading over the desert in every direction for the next 3 or 4 miles, but it should be easy to find the main road leading northwest. It passes near the base of the mountains but does not enter them. Roads leading to the south or west go to Ogilby.

20.0 The road crosses a wash in the foot of the mountains, and a branch road leads east (right) up the wash to Tumco, whose deserted houses are conspicuous half a mile away. Usually there is no one at that place, and no water can be obtained. Continue northwest without passing through Tumco.

21.5 A branch road leads to the right, going to a place called Hoges Ferry, on Colorado River. There was a board sign at the fork in 1918. Take left-hand road, passing northwest across a smooth gravelly plain with few landmarks. 
33. 0 At about this distance the road enters a large wash in which ironwood trees are abundant. The wash is a little sandy but should not be difficult for automobiles.

38.5 A good road entering from the southwest is the Glamis-Blythe road. Geological Survey sign at the fork. For a detailed log of the road from this point into Blythe set gage to 14.3 and use the GlamisBlythe $\log$ (p. 59). As the road is easy to follow nearly all the way into Blythe, the following continuous readings out of Yuma may be sufficient for many persons.

45. 4 Smith Well. Mining camp. Fair water.

54. 8 Summit of pass in Palo Verde Mountains.

64. 0 Palo Verde. Store and post office. Water and gasoline.

68. 7 Rannells. Store and post office. Water and gasoline.

82. 7 Blythe. Water, supplies, and hotels.

\section{YUMA TO PICACHO.}

Two miles north of Yuma, in Yuma Valley, a road goes north from a corner marked by a Geological Survey sign. This is the road to Picacho. Three miles north of the corner the road crosses a bridge over the Highline Canal in Yuma Valley, and about a mile farther north ascends a bluff out of Yuma Valley and continues north over the "mesa" and through the Picacho Hills into Picacho, the total distance being probably less than 20 miles from Yuma, although locally called 25 miles. The road has seldom been traveled by automobiles and is almost impassable because of sand along the terrace bluff 5 miles from Yuma. The rest of it is reported as fair. The road was not traveled and no accurate description can be given.

Water for domestic use at Picacho is said to be derived from wells in a little valley called Picacho Wash. Water for mining has been obtained from Colorado River.

\section{YUMA TO LAGUNA DAM.}

Several dirt roads of fair quality lead northeast through Yuma Valley, on the California side of the river, to Yuma dam, or Laguna dam, as it is now named. One road goes east from the same corner, where the Picacho road goes north, 2 miles north of Yuma. The distance is about 11 miles. There is a little settlement called Potholes at the dam, and a few caretakers live there.

\section{BLYTHE-BLYTHE JUNCTION.1}

\section{BLYTHE TO BLYTHE JUNCTION (41 MILES).}

0. 0 Blythe. Post office, two blocks east of railway crossing. Start west.

0.5 Geological Survey and Auto Club signs. Turn north (right). Road west goes to Mecca. Road south goes to Yuma and Imperial valleys.

1. 0 Crossroads. Road going west may be taken for Mecca. Continue north, ignoring branch roads, which serve near-by ranches.

5.5 Auto Club sign. Cross large canal and take left-hand road. This continues nearly straight north from canal for about 300 feet and then turns sharply west. Next mile is sandy. Road to right goes to Blythe Intake. (See p. 65.)

6.1 Cross railway and turn north, climbing sandy grade to terrace.

6. 4 Edge of terrace overlooking Palo Verde Valley. Go northwest. A telephone line runs near the road most of the way to Blythe Junction.

13. 4 Branch road enters from south. It is another route leading from Blythe by way of Graham Well but is very sandy and little used.

1 The name of Blythe Junction has been changed to Rice since this guide was written. 
18. 5 Trail leads northeast to mining prospect. Continue straight.

20.0 Geological Survey sign. Branch road turns west to Mineral Switch, 500 feet away, on railway, and continues to Chandler Well, Adams Well, McCoy Spring, ete. (See p. 66.) Water may be obtainable at Mineral Switch in emergency, as it is hauled there for mine supply. Continue straight.

22.2 Branch road west paralleled by telephone line goes to gypsum mines, 2.8 miles away. Continue straight.

23. 2 Crest of low pass between Maria and Little Maria ranges.

23. 4 Cross the railway.

25.5 Branch road turns to left at small angle. This leads to Gyp Well, I mile away, derrick over which is visible from this point. Mileage given on straight (right-hand) road.

26. 3 Geological Survey sign. Branch road goes west to Gyp Well, one-fourth mile away. This may also be followed $3 \frac{1}{2}$ miles west to Mohave Tank, in the pass plainly visible in the Little Maria Mountains. Water is obtainable at Gyp Well when the gypsum mines are being worked. Continue northwest.

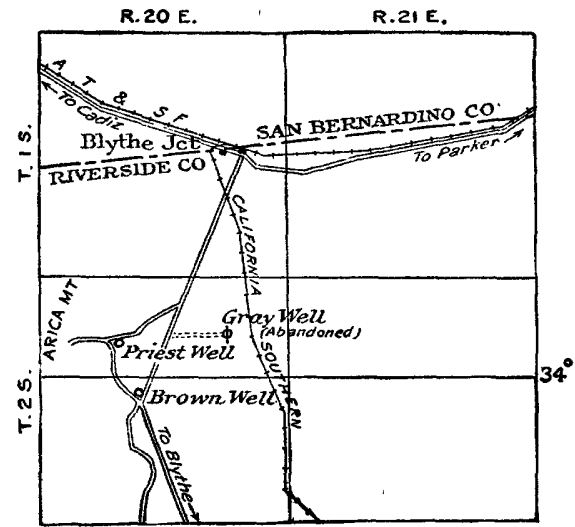

FIGURE 1. - Sketch map of vicinity of Blythe Junction, Calif.

26. 6 Branch road returns from Gyp Well.

28.9 Road forks. Both roads lead to Brown Well and Blythe Junction and both are bad. Right-hand road is very sandy and at places planked. Left-hand road is crooked, crosses many washes, and is 1 mile longer. Mileage is given over left-hand road, which is probably preferable.

34. 4 Brown Well. Roads rejoin. Mileage over east branch is 33.4. Water at faucet from tank beside well. Branch road turns northwest, around a house, and leads to mine in Arica Mountain. Main road goes northeast. .

36. 3 Trail leads east to Gray's mill and well (abandoned).

37. 1 Planked road over bad sand begins. A road leads southwest to Priest Well and a mine in Arica Mountain.

39. 1 End of planked road.

39. 5 Cross California Southern Railway.

40. 6 Geological Survey sign. Branch road goes east to Parker.

40.8 Blythe Junction. Branch road goes west, along railway, to Cadiz, Barstow, etc. (See fig. 1.) 


\section{BLYTHE JUNCTION TO BLYTHE (41 MILES).}

0. 0 Blythe Junction. Post office. Start south. Telephone line runs along road most of way. (See fig. 1.)

0.2 Branch road turns east to Parker. Continue on right-hand road, leading south.

1. 3 Cross California Southern Railway.

1. 7 Planked road across drift sand begins.

3. 7 End of planked road. Branch road goes west (right) to Priest Well and to mine in Arica Mountain.

4. 5 Trail leads east to Gray's mill and well (abandoned).

6. 4 Brown Well. Water at faucet from tank beside well. A branch road comes in on northwest from mine in Arica Mountain but is hardly noticeable. The main road forks here; one branch goes slightly southwest (right) over crooked road that crosses numerous washes, and the other southeast (left) along telephone line. The left-hand road is 1 mile shorter but very sandy. Both roads are bad. 'Mileage was measured over right-hand road.

11.9 Branch road rejoins (mileage 10.9 on left branch). Continue southeast.

14. 2 Road forks. Road to right goes by way of Gyp Well, derrick of which is visible. Mileage given on straight road (left).

14. 5 Geological Survey sign. Branch road west to Gyp Well, one-fourth mile away. May also be followed to Mohave Tank, $3 \frac{1}{2}$ miles west, in pass visible in Little Maria Mountains. Water may or may not be obtainable at well. It is always obtainable when gypsum mines are being worked and may be drawn from tank through faucet.

15.3 Branch road returns from Gyp Well.

17. 4 Cross the railway.

17. 6 Summit of pass through Maria Mountains.

18. 6 Branch road west paralleled by telephone line leads to gypsum mine, 2.8 miles away.

20.8 Geological Survey sign. Branch road turns west to Mineral Switch, 0.1 mile away, on railway. It leads westward to Chandler Well, Adams Well, McCoy Spring, etc. Water may sometimes be had at Mineral Switch in emergency, as it is hauled there for mine supply.

22. 3 Trail leads northeast to mining prospect.

27. 4 Branch road goes south (right). It is a little-used road to Blythe by way of Graham Well. It is passable but sandy. Water not obtainable at Graham Well in 1918. Use left-hand road.

34. 4 Edge of terrace overlooking Palo Verde Valley.

34. 7 Cross railway and turn east, over sandy road.

35. 3 Auto Club sign. Turn due south across large canal. Ignore branch roads, which serve near-by ranches.

40. 3 Geological Survey and Auto Club signs. Turn east (left). Road west goes to Mecca. Road south goes to Yuma and Imperial Valley.

40. 8 Blythe. Post office, two blocks east of railway crossing.

\section{BLYTHE TO BLYTHE INTAKE.}

About 5 miles north of Blythe a branch road goes northeast from the Blythe Junction road. It leads to Blythe Intake, which is about 7 miles from the road fork. The road is passable, at least for wagons, but is said not to be very good. 


\section{BIYTHE INTAKE TO PARKER.}

There is an ancient trail along the river from the Blythe Intake north as far as Parker, Ariz. It is probably not passable for vehicles. C.' $H$. Baldwin, of Blythe, describes it as follows: "For a few miles north of Blythe Intake the trail passes through some rough 'badland' hills, the border of the Maria Mountains. Later it crosses swampy land between the mountains and the river, there being a big slough on the east. An abandoned limekiln is along this part of the road.' Not far from the limekiln a canyon comes from the west, and up it a burro trail leads to Willow Spring and on across the Maria Mountains. The river trail continues northward to Parker."

\section{MCCOY SPRING, ADAMS WELL, CHANDLER WELL, AND McCOY TANKS, FROM BLYTHE AND BLYTHE JUNCTION.}

Note.-The only reasonably good way of reaching the place's named above from Blythe is to use the main Blythe Junction road as far as Mineral Switch, a siding on the California Southern Railroad, 20 miles from Blythe. The traveler is therefore referred to the $\log$ on page 63 for the first 20 miles of the route. Persons going from Blythe Junction to any of these watering places will also turn off at Mineral Switch, which is 20.8 miles south of Blythe Junction. (See log, p. 65.)

\section{MINERAL SWITCH TO MCCOY SPRING (22 MILES).}

0. 0 Geological Survey sign, 0.1 mile east of Mineral Switch. Turn west toward railway.

0.1 Mineral Switch (formerly English Siding). This is a shipping point for mines in the near-by mountains, but usually no one lives here. and there are no buildings. Water is hauled here by the railway company for miners' supply and is sometimes obtainable. Cross railway. Continue west then southwest.

1. 2 Road forks. Take either branch. Distance was measured on right-hand road.

2.7 The two branches unite, and road leads southwest through a group of scattered hills at the south end of the Little Maria Mountains. On leaving the hills the road turns west.

9. 2 Crossroads. Geological Survey sign. To reach Chandler Well turn north and follow the road 4 miles. This well is 17 feet deep, and yields good water. The road south leads to McCoy Tanks. (See appendix to this $\log , \mathrm{p}$. 67.) To reach McCoy Spring continue west.

10. 2 Another branch road leads south to McCoy Tanks. Continue west.

10.8 Three-way fork. Geological Survey sign. The left-hand road leads to Black Jack Camp, where some manganese mines, visible about a mile away on the mountain side, were being operated in 1918. The righthand road goes to Adams and Packard wells. (See appendix to this $\log$, p. 67.) The middle road leads to McCoy Spring.

12.5 At about this point the road crosses some sandy washes, branches out in several ways, and becomes rather indefinite. There is a Geological Survey sign at the most doubtful point. Go south from the sign, keeping from 1 to 2 miles west of the McCoy Mountains but east of the wide wash draining south toward Ford Dry Lake. The road is very dim at places and is badly washed out along numerous gullies.

15. 3 A plain road leads east (left) to an abandoned mine in the mountains. Continue south. 
16. 2 A county signpost stands on the west side of the road, where a dim trail leads west (right). Continue south.

19. 8 County signs and a Geological Survey sign mark dim crossroads. The * trail that continues south leads to Ford Well but is impassable for automobiles. The road west joins the Mecca-Blythe road about 14 miles away but is known to be very bad. Turn east (left) to reach McCoy Spring.

22. 1 The road ends at a little flat bench on the south side of a gully at the west base of the McCoy Mountains. McCoy Spring is about 150 feet east in the bed of the main gully. The water is good if clean from the surface filth.

\section{MINERAL SWITCH TO MCCOY TANKS (11 MILES).}

From Mineral Switch go over McCoy Spring road, as indicated in preceding log, to Geological Survey sign at crossroads (9.2).

9. 2 Geological Survey sign at crossroads. Turn south (left).

10. 3 Crossroads. County sign. The road that is crossed comes from the north and leads southeast to Blythe. It is little used and in bad condition. For McCoy Tanks go southwest into the mountains on a dim road that leads toward a large canyon.

11. 1 McCoy Tanks. Fnd of the road at north edge of canyon. One of the tanks is a few hundred feet east (down the canyon); the other is about half a mile west. Both of the tanks are often dry in summer.

\section{MINERAL SWITCH TO ADAMS WELL.}

From Mineral Switch go over McCoy Spring road, as indicated in preceding $\log$, to Geological Survey sign at three-way fork (10.8).

10. 8 Geological Survey sign at three-way fork. For Adams Well turn to the right. The road leads northwest over badly dissected desert basin. It is rather dim and bad at places but generally passable.

21. 6 A Geological Survey sign stands at the entrance to a canyon which once afforded a pass for a wagon road through the Palen Mountains. A wagon or possibly even an automobile might proceed as far as Adams Well, but it is best to walk the rest of the way if traveling in a car. The distance to Adams Well is about 1 mile. Packard Well is about 3 miles farther on the west side of the mountains, but not even a wagon could have traveled the dim canyon trail in 1918. Adams Well is about 43 feet deep, and has water 20 feet below the surface. The Packard Well is said to go dry sometimes.

\section{OID ROUTE FROM MCCOY TANKS TO PATTERSON AND GRAHAM WELIS.}

A practically abandoned trail leads southeast from the old county sign, half a mile north of McCoy Tanks and in various ways connects with Patterson Well and Graham Well. Portions of it were traveled by the writer. The distance from McCoy Tanks to Graham Well is 19 miles, but McCoy Wash is so sandy as to be practically impassable for cars. Branch roads lead southeast, avoiding the wash, and an automobile could probably get through safely from McCoy Tanks to Patterson Well. The Graham Well was abandoned in 1917 and no water was obtainable. 


\section{MECCA TO COTTONWOOD SPRING, IRON CHIEF MINE, DALE,} ELDORADO MINE, PINYON WELL, AND INDIO.

\section{MECCA TO DALE BY WAY OF COTTONWOOD SPRING.}

0. 0 Mecca. Public water fountain just north of railway station. Start east.

0.9 Geological Survey sign. A branch road leads south to Dos Palmas, etc. (See p. 50.) Continue east.

3. 2 Auto Club sign.

3.9 Turn northeast, passing under electric transmission line. A branch road following the transmission line is used chiefly by linemen but oc. casionally by travelers who go southeast (right) at this point to Dos Palmas. (See p. 55.) Continue northeast, up a sandy slope.

6. 0 Enter Shaver Canyon and pass through an area of badlands several miles wide.

12.1 Shaver Well, on north side of road. Good water. Continue northeast, up canyon, which becomes merely a wash half a mile farther on.

12. 6 Road forks. Auto Club signs. Right-hand road goes to Blythe. Take left-hand road for Cottonwood Springs and Dale. For several miles, it leads up a rather sandy wash.

16. 2 County sign. A branch road that continues east is the old road to Blythe. Turn to the left on plainest road, passing up the slope of a steep alluvial fan.

20. 4 The road enters a canyon at the edge of the mountains, crossing the very sandy canyon bed at this point.

20. 8 County sign. The road turns north up the east side of the canyon avoiding the deep sand in its middle.

22. 0 The road takes the center of the very sandy canyon bed. Autos may have difficulty here. Continue up the canyon between low granite walls. At one place the road goes over a short steep cut in rock at the side of the canyon.

23. 5 Branch road leads east (right) to Cottonwood Spring, visible about 100 yards away, where there is excellent water. Near spring is a house and a grove of cottonwood trees. Road to Dale continues up the canyon until it emerges from the mountains upon a rolling upland.

25. 0 County sign. A dim branch road leads northwest (left) to Pinkham Well. Take right-hand road for Dale.

31. 3 Branch road turns west (left) to Twenty-nine Palms, Pinyon Well, etc. (See p. 69.) About 100 feet farther north another branch road turns east (right) to the Iron Chief mine. Both forks are posted with county signs. Use the center road to reach Dale.

The road from this point to Dale was not traveled by the writer. It is known to pass first over a long, broad desert basin. About 15 miles from this fork (approximately 46.0) it reaches the Brooklyn mine, in the south edge of a low mountain range. If a watchman is present at the place water may be obtainable. From the Brooklyn mine the road goes northwest through the mountains to New Dale, a mining camp, once prominent but abandoned in 1918, about 4 miles away (approximately 50.0). No water is obtainable at New Dale. From New Dale a road leads northwest across a sandy desert basin to old Dale, 6 miles farther. It is probable that a road also leads north from New Dale to a pumping plant 6 miles away, in the edge of a "dry lake."

At Old Dale will be found an abandoned well with a broken windmill, an unused pumping plant, and a few ruined adobe huts. A road leads northeast to Amboy, and $2 \frac{1}{4}$ miles away on this road is a well with windmill at which 
water was obtainable in January, 1918. A road leads west from Old Dale into Banning. (See p. 71.) An automobile may approach within about a mile of this well, but for the rest of the way the drift sand is deep and almost impassable.

\section{IRON CHIEF MINE.}

At 31.3 milcs from Mecca a branch road goes east (right) to the Iron Chief mine, a noted but lately inactive property in the Eagle Mountains. This road is reported to be passable by automobile. There is a county sign at the road fork. Water hauled or pumped from Cottonwood Spring may be obtainable at the Iron Chief mine when the mine is operated.

\section{ROAD WEST FROM COTTONWOOD SPRINGS.}

At $1 \frac{1}{2}$ miles north of Cottonwood Spring (25.0) a branch road marked by an old Riverside County sign goes west (left) to various portions of the Cottonwood Mountains and is reported to end somewhere about 10 miles west. Its location as given on the map is adopted from recent Land Office surveys and is probably reliable. It serves prospectors in the region west of Cottonwood Spring. Its condition was not ascertained, but from the nature of the country it ought to be good for several miles.

\section{COTTONWOOD SPRING TO ELDORADO MINE AND PINYON WELL (31 MILES).}

0. 0 Cottonwood. Spring. Go north, up a sandy canyon, emerging in an upland region.

1. 5 County sign. Branch road turns left. Take right-hand road.

7. 7 A county sign marks a road fork turning to the left, and another marks one leading to the right about 100 feet away. Turn left on a dim road at the first sign. The road straight ahead leads to Dale, and the righthand road goes to the Iron Chief mine.

7.9 to 10.5 The road passes through an upland from which rise a great many isolated granite peaks and hills. The road is rough but easily traversable. On emerging from the hills the road for several miles skirts some low broken mountains which lie a short distance west and then leads northwest, across a basin several miles wide lying south of the Pinto Mountains.

17. 7 A dim trail comes in from the east. In January, 1918, it was marked by a small board sign that pointed along it to the Brooklyn mine and Dale. Nothing more is known of it. The road to Eldorado leads nearly west, across a rather sandy basin.

20.2 Road fork. The right-hand branch leads northwest to Twenty-nine Palms and does not pass the Eldorado mine. Its condition was not ascertained, but it could probably be used as a cut-off to Twenty-nine Palms. It intersects the road from Eldorado to White Tanks and Twentynine Palms, about a mile away. (See p. 71.) There was a small board sign in 1918. Take left-hand road for Eldorado mine.

21. 3 A road leads north, around the mountain, to White Tanks and Twentynine Palms. (See p. 71.) For Eldorado mine continue west, entering a canyon.

21. 8 Eldorado mine. House and other buildings in canyon. Water piped from Pinyon Well is obtainable when the mine is worked. For road to Banning, see $\log$ (p. 71). To reach Pinyon Well continue west. The road leads up a small narrow canyon and crosses a low divide.

24. 5 A cut-off leads straight ahead (west) but is ,rough and rocky. ' Just north of the road fork is a faucet in the pipe line leading from Pinyon 
Well to the Eldorado mine, and good water may be had when the mine is worked. Turn left (south).

24. 8 The road turns west, up a wash, around an abandoned cabin and mill.

25. 4 The branch road noted at 24.1 enters from the east. Continue west, up the wash.

26. 3 Road fork. The right-hand road is the best route to Banning. One may also follow it to the Geological Survey sign at the Gold Coin mine 1.6 miles from this fork, and there turn southwest to Pinyon Well. The left-hand road is given because it is equally good and is shorter.

28. 8 Road from Gold Coin mine enters from northeast. Continue southwest. 29.9 Enter canyon in Little San Bernardino Mountains. A county sign points north on a dim branch road to Twenty-nine Palms. Continue up the canyon, which is sandy at places.

30.6 Pinyon Well. Two dilapidated cabins and the ruins of a stamp mill indicate the place. Good water can be had at well between the road and the cabins. If it is desired to continue up the canyon to Indio, see $\log$ below.

\section{PINYON WELI TO INDIO (21.7 MILES).}

NoтE.-The road from Indio to Pinyon Well was originally made to connect Indio with mining properties in the vicinity of Pinyon Well and Pleasant Valley, but in 1918 it was almost unused for any purpose. It is practically impossible for automobiles to travel from Indio to Pinyon Well on account of sandy grades and very steep hills; but they can safely go from Pinyon Well into Indio, as the road is nearly all downhill. Accordingly the log and description are given in this direction. It may accommodate persons either from Banning or Cottonwood Spring who wish to use a short cut into Indio from Pleasant Valley.

0. 0 Pinyon Well. Start southwest, up a.sandy canyon. There is a county sign near the well.

1.3 A large tributary ravine enters the main canyon, which swings west at this point, and a dim trail leads over the hill between the two canyons to Henson Well, about three-fourths mile south. Continue west, up the main canyon.

1. 7 Summit of the pass over the Little San Bernardino Mountains. Continue west, down a very steep hill along a deep canyon with sandy bed.

6. 8 County well, on south (left) side of road. Water is obtainable with rope and bucket, which are usually provided, and is of good quality. There is a county sign opposite the well. Continue down the canyon.

10.5 The road emerges from the canyon upon a rocky slope and turns southeast, down a sandy wash, passing between the base of the Little San Bernardino Mountains on the east and an isolated mountain ridge on the west. This ridge on the west gradually diminishes toward the south and ends in a strip of clay hills.

17.9 The road turns suddenly southwest, ascending a very sandy slope, passing through a gap in the clay hills mentioned above, and emerging upon Coachella Valley in sight of Indio.

19. 1 The road branches at about this point, and a fork leads to the right, directly toward Indio. Use the road to the left (south), which is probably better.

19.9 Ranch house. Go due south.

20. 2 Crossroads. Turn west (right), along telephone line, on good dirt road.

21. 2 Crossroads. County sign. Turn south (left) to Indio. 
21. 7 Indio. Railway station. Water, hotel, supplies. To reach the highway leading to Los Angeles or Imperial Valley continue south half a mile.

ELDORADO MINE TO TWENTY-NINE PAIMS BY WAY OF WHITE TANK.

0. 0 Eldorado mine. Go east, down the canyon.

0.5 Road fork. Right-hand road leads east to Cottonwood Spring. Turn left, crossing about 3 miles of very rocky alluvial slope.

2. 0 A branch road enters from the south, coming from Cottonwood spring. Continue north, up a wide pass between the Hexie and Pinto mountains.

3. 5 Road becomes very dim and crosses a sandy wash for about a mile.

4. 0 A dim branch road leads west (left) toward Keys ranch. Continue northwest, up the main pass. A county sign marks this fork.

7.5 The road here has reached a high upland plain and passes a number of huge white granite masses that rise as smooth isolated blocks. The scattered rubbish left by campers is usually to be seen around these rocks. About half a mile east is White Tank, in a small gorge that passes through these granite masses at the west base of Pinto Mountain. Only cattle trails lead in that direction, indicating its location. Water most of the year. Continue north for Twenty-nine Palms. The route is not definitely known to the writer beyond this point, but the road is easily passable for automobiles and reaches Twenty-nine Palms about 9 miles away (total reading approximately 16.5). About 4 or 5 miles beyond the vicinity of White Tank it joins a road from the west that comes from Quail Spring and Keys ranch.

\section{BANNING TO DALE.}

[See fig. 2.]

0. 0 Banning. Two blocks north of railway station. Start east over paved road.

1. 0 Southern Pacific Railroad. Go east along track.

5. 8 Cabezon railway station and store. Water and gasoline. Continue east along railway.

12.9 Geological Survey sign. Dale road turns northeast (left), away from the main road, which continues southeast to Coachella Valley. It is sandy at first.

13.1 Turn straight east. There are numerous signposts recently erected by the Automobile Club of Southern California along this portion of the route. but their exact location is not given.

13. 8 Turn north.

13.9 Turn northeast, up a sandy and rocky slope. There are a number of houses in this vicinity.

14. 4 A branch road leads south (right) to Whitewater. Continue northeast.

14. 8 Cross bridge over Whitewater River.

14.9 A branch road to the right at the foot of a hill leads to Palm Springs station. Take the left-hand road, which is cut in the side of the steep hill. An Auto Club sign has been erected here. The road reaches the top of the steep grade not far away and turns northeast over a sandy table-land.

18.3 A dim trail leads to the left. Continue on plain road (right). 


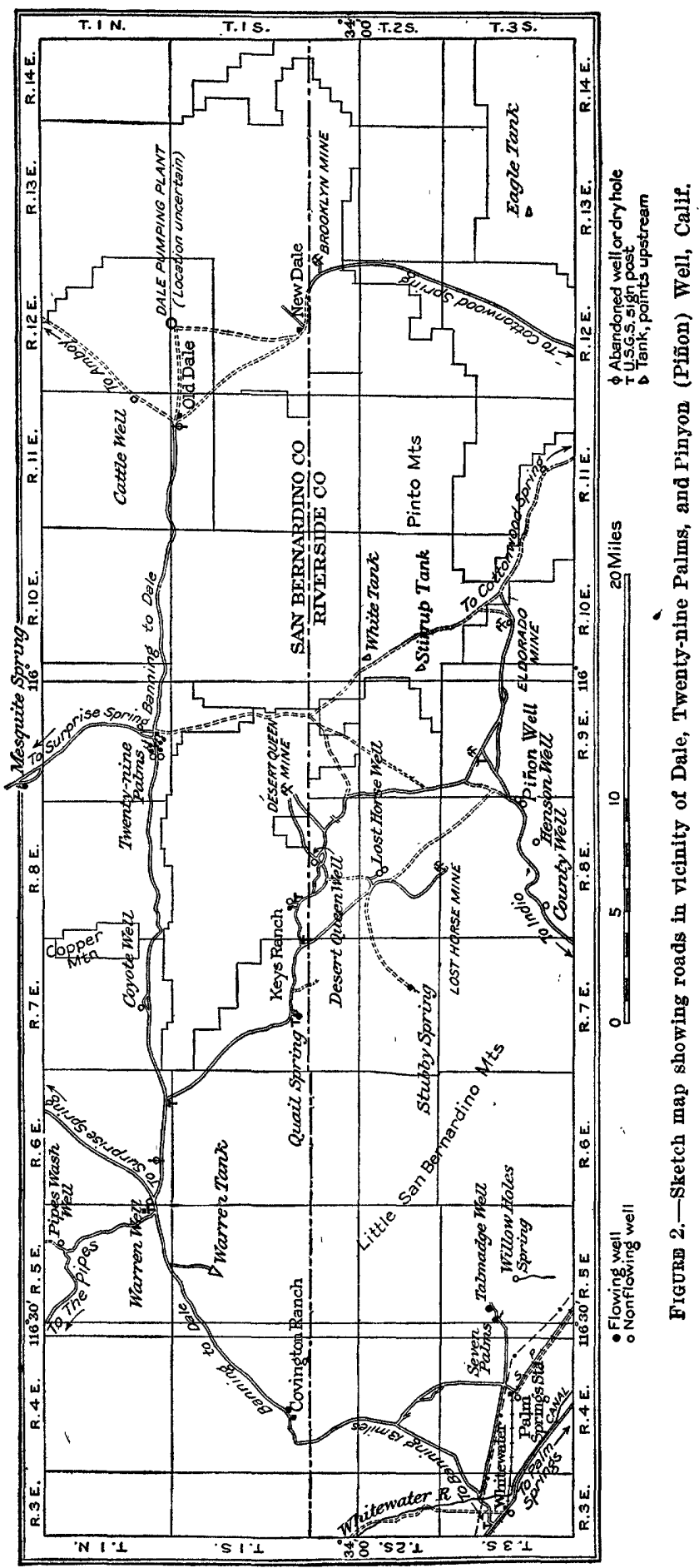


20. 4 Crossroads. Auto Club and private signs. Road northwest (left) leads to Mission Creek ; road southeast leads to Palm Springs station. Continue straight ahead, northeast. The road is sandy and difficult at places. '

21.5 A branch road leads northwest (left). In January, 1918, a board sign directed along this road to the $T+/ K$ ranch, $1 \frac{3}{4}$ miles away. Continue northeast (right).

22. 6 Enter canyon passing through foothills of San Bernardino Mountains. The road goes north up the gorge.

23. 4 Water runs in the canyon at this point during most of the year.

25. 1 On a steep grade an Auto Club sign points west along a footpath to Hole-in-the-wall Spring. Water is obtainable about 100 yards away on this path.

25. 3 Summit of pass through San Bernardino Mountains. Overlook Morongo Valley, which lies north.

25.5 Road turns straight east, passing a house at which is a well not far away.

26. 0 Road turns due north.

26. 2 Turn straight east. A branch road continues north.

26. 5 Pass through a gate on the ranch of $W$. V. Corington, formerly callerl Warren ranch.

26. 8 Covington ranch (Warren ranch). Good water. Small stock of provisions and a supply of gasoline-probably the last available on this route. Continue north from ranch.

27. 0 Cross Big Morongo Creek, a small stream of good water.

27.1 Pass through gate, out of Covington ranch. Continue northeast, over main road, which is at places sandy and rocky but a fair automobile road.

29. 7 A branch road leads to the right to a house about one-fourth mile away. Continue north on main road, finally ascending a long grade out of Morongo Valley.

34. 0 Crest of divide at northeast end of Morongo Valley. The road descends a short steep slope into another valley, sometimes called Yucca Valley.

35. 4 A crossroad leads north and south, but main road goes straight ahead toward east. The road leading north is an old wagon road to The Pipes, but it was not passable in 1918. The road to the south is said to lead to a place called Warren Tank, about 2 miles away, where water is obtainable in a small tunnel.

38. 2 Geological Survey sign. A branch road turns north to The Pipes. A house stands 0.1 mile east, and a well with windmill is in front of the house. This is the Warren Well.

38. 3 Warren Well. Good water is kept in a reservoir. A road is said to turn to the left (just east of this well) and to go north to Surprise Spring, but nothing could be seen of it. Continue east, across a small playa, on the main road, which for the next 20 miles is excellent desert road. A few trails lead north and south in the next 3 miles, but the main road is unmistakable.

43. 0 Road forks. Geological Survey sign. Right-hand branch leads southeast to Quail Spring and Pinyon Well. (See p. 74.) For Dale continue east on right-hand road.

47.2 A branch road turns left, leading to Coyote Well, one-fourth mile away, over which a windmill is visible. Water. For Dale continue east (right). 
48. 0 Branch road returns from well. Continue east.

58. 7 House on north side of road, sometimes occupied by miners. Wells, on north and south sides of road, where water is obtainable, but it is only a mile to Twenty-nine Palms. Continue east.

59. 0 A branch road leads southeast (right). Continue east (left).

59. 5. A branch road leads northeast (left) to Mesquite Spring. Continue east (right).

59. 7 Twenty-nine Palms. The palms stand in a long row south of the road. There is a house at this point and two or three springs within a few hundred feet. Paths lead to the springs, which can be found easily. Any one that is in good condition is satisfactory. Continue east, for Dale. A branch road also leads north from the house to Mesquite Spring, but it is not plain.

59.9 A branch road leads south to Eldorado mine and other points. (See p. 71.) Continue east.

61.9 Enter a small canyon, which affords a pass through a low ridge of granite.

62. 9 Emerge from pass through granite ridge.

67. 0 The road is very sandy for the next 2 miles.

69. 0 A branch road turns southeast (right). Continue on left branch. The road becomes less sandy for a distance.

72. 0 Sand becomes very bad again. Deflates tires if necessary.

73. 8 Old Dale (also called old Virginia Dale). The remains of a few adobe houses, a broken windmill over a well that is badly caved, and a pump house on a little eminence to the east indicate the place. To reach New Dale, the mining camp, continue east, over the hill by the pump house, and then follow the road southeast. This road was not traveled by the writer. It is known to be sandy. The distance from old Dale to New Dale is reported to be 6 miles. There was no one at New Dale in January, 1918. From old Dale a road goes north to Amboy, about 40 miles away on the Atchison, Topeka \& Santa Fe Railway. It is very bad-almost impassable for automobiles.' One may get water, however, at a well 21/4 miles northeast of Old Dale on this road. It is possible to approach safely by automobile within about a mile of this well, but in the last mile the sand is deep and very difficult to cross. There is a windmill over the well, which supplied water to range cattle in 1918.

BANNING TO QUAII SPRING, KEYS RANCH, PINYON WELL, AND ELDORADO MINE.

[See fig. 2.]

This road branches from the Banning-Dale route 43 miles east of Banning and 4.7 miles east of Warren Well. It will generally be used by persons coming from the west. Distances are therefore made to read from Banning, and the traveler is referred to the Banning-Dale $\log$ (p. 71) for the route as far as the road fork.

43. 0 miles from Banning (4.7 miles east of Warren Well). Road forks. Geological Survey sign. Take the right-hand road to Quail Spring. The left-hand road continues east to Dale. Proceed southeast, up a long wash that is rather sandy at places. 
50.5 Geological Survey sign. Branch road goes south (right) to Quail Spring. Good water in a reservoir 0.1 mile away. For Keys ranch and Eldorado mine turn east (left) over main road.

51.5 A plain but little-used road leads south (right) to a cabin about 2 miles away. Continue east.

53:3 Geological Survey sign. A plain road leads to the right, going to Lost Horse Well and Lost Horse mine. Continue east (left).

55. 7 A plain road branches to the left, going to Keys ranch, half a mile away. There is another branch a little farther on. Continue to the right.

55.9 Geological Survey sign. A branch road goes north to Keys ranch, visible about half a mile away, where good water can be obtained. For points beyond follow the main road southeast.

56. 0 Road forks. One branch leads east, the other southeast. The two reunite not far away. Take the southeast (right) branch, which is less sandy and usually better.

57. 0 A dim road goes south to Lost Horse Well. (See p. 81.) Continue on plain road to left.

58. 2 Branch road noted at 56.0 enters from the west. At nearly the same place a branch turns northeast (left) to a windmill which can be seen about half a mile away. This is the Desert Queen Well, where water was not obtainable in January, 1918. For points beyond, continue east (right).

58. 7 A branch road returns from windmill noted above. Continue east.

60. 0 A branch road leads east to the Desert Queen mine, 2 miles away. Turn to the right and go southeast. The road is not much used and is rather sandy at places in the next few miles.

60.7 A faint cross trail leads east and west. Continue southeast, straight ahead.

61. 8 County sign. A branch road leads east to Twenty-nine Palms. Go southeast (right).

63. 2 County sign. A branch road leads east (left) to Cottonwood Spring. Continue south (right).

65. 7 County sign. A branch road coming from Twenty-nine Palms enters on the left. Continue south.

67.5 The main road swings east (left) into a little basin called Pleasant Valley. A very faint trail may be seen leading'south. It is a short cut to Pinyon Well and is probably passable but was not traveled by the writer. Continue east, as there is a good road not far away.

68.7 Point is on a small playa in the center of Pleasant Valley. Geological Survey sign. Abandoned buildings of the Gold Coin mine are conspicuous 0.1 mile east. The road continues east to the Eldorado mine. (See log, p. 76.) To reach Pinyon Well turn southeast (right). The Geological Survey sign at this point gives 28 miles as the distance to Indio, but it really is only 25 , the road not having been measured when the sign was erected.

69. 9 Going southwest on road to Pinyon Well. A branch road enters from the east, coming from the Eldorado mine. Continue southwest.

71.0 The road enters a canyon in the Little San Bernardino Mountains. County sign, on the north side of the road, directs north along a dim trail to Twenty-nine Palms this being the other end of the branch road mentioned at 67.5 .

71. 7 Pinyon Well. Two tumble-down cabins and the wreck of a stamp mill identify the spot. The well is on the left (east) of the road, be$157138^{\circ}-20-6$ 
tween the road and the houses. A rope and bucket were provided in 1918 and good water was obtainable. To reach Indio from Pinyon Well, see $\log$ of Pinyon Well to Indio road (p. 70). This road continues up the canyon from Pinyon Well, and a county sign stands near the well.

\section{Road to the Eldorado mine.}

68. 7 Geological Survey sign on playa in Pleasant Valley, near Gold Coin mine. From this point, in the above log, continue east to reach Eldorado mine.

68. 8 Pass by buildings of Gold Coin mine, which was abandoned in 1918.

70.3 A plain road enters from the west (right), coming from Pinyon Well. Continue east, down a sandy wash.

71. 2 Road forks. A plain road leads to the left over a hill. It is a small cut-off but is rocky and little traveled. Continue to the right, down the wash.

71. 8 Pass an abandoned cabin and mine building and turn north (left), out of the wash.

72.1 The branch road noted at 71.2 enters from the west. Road turns abruptly east. About 20 feet north of the road at this turn there is a faucet in a pipe line which is buried near the road. The pipe line leads water from Pinyon Well to the Eldorado mine. Good water is obtainable at the faucet when the mine is worked. Continue east over a hilly country, later going down a small canyon leading east.

74.8 Eldorado mine. House and mine buildings are conspicuous in canyon. Water piped from Pinyon Well when mine is operated. A road goes east to Cottonwood Spring (p. 69) and another goes north to Twentynine Palms (p. 71).

\section{WHITEWATER TO PATIN SPRINGS STATION.}

From a point 1 mile west of Whitewater, or 12.9 miles east of Banning, a road goes northeast from the Banning-Coachella highway. (See Banning-Dale log, p. 71.) From it a branch road leads east to Palm Springs station (Gray post office), on the Southern Pacific Railroad, 6 miles east of Whitewater. The road is sandy and rather bad but passable, although rarely used by automobile. A log is hardly necessary but the route may be summarized as follows:

0.0 Geological Survey and Auto Club signs on Banning-Coachella highway, 1 mile west of Whitewater. Take the Banning-Dale road leading northeast.

2.1 Auto Club sign. Take right-hand road at foot of hill just east of Whitewater River. Follow a power line east for several miles.

7. 0 Crossroads. Road north leads to Morongo Valley and Dale. Road east leads to ranches of the neighborhood. Road south leads to Palm Springs railway station, which is easily seen.

7. 4 Palm Springs railway station, consisting of one or two houses and a station.

\section{PALM SPRINGS TO PAIM CANYON.}

From the resort at Palm Springs, Riverside County, a road goes south to Palm Canyon. It leaves the main Coachella Valley highway $1 \frac{1}{2}$ miles southeast 
of Palm Springs and goes south (right). The road is adequately posted with private signs and is a fair automobile road. It is considerably used by tourists and sightseers, especially by patrons of the resort at Palm Springs. It ends 6.1 miles from Palm Springs, where the canyon becomes impassable for vehicles.

About 3 miles from Palm Springs on this road there is an irrigated oasis, known as the Garden of Eden, which belongs to Indians of the Agua Caliente Reservation. They obtain water from Andreas Canyon by a diversion dam and conduit.

Palm Canyon is a scenic attraction of much beauty. There is running water along a narrow canyon valley for severral miles, and extensive groves of stately native palms. The canyon is walled by jagged and precipitous mountains on each side and extends back nearly to Toro Peak, 8,000 feet high. At the entrance to the canyon is a unique hermitage. A footpath extends for a considerable distance beyond the road into the more attractive scenic area.

\section{WATERING PLACES. .}

Adams Well.-Page 67; Plate VII.

Agua Caliente Springs.-Pages 40-42; Plate VI.

Agua Dulce.-An artesian spring of the Figtree John and Fish springs variety. It was once an important watering place but is now supplanted by the artesian wells of neighboring ranches. It is in sec. 19, T. 8 S., R. 9 E., in southern Coachella Valley. (See Pl. VI.)

Alamo Bonito.-A group of artesian springs near the Coachella-Brawley road in southern Coachella Valley. Was once an important watering place but is now little used, owing to the development of artesian wells on surrounding ranches. The springs are understood to be similar to Figtree John and Fish springs. They are in sec. 35, T. 7 S., R. 8 E. (See Pl. VI.)

Alamorio.-Village 4 miles east of Brawley. (See Pl. VII.) Flowing well in the village.

Alamo School.-Pages 29, 31 ; Plate VII.

Amos,-Pages 23-26; Plate VII.

Andreas Canyon.-Page 77 ; Plate VI.

Angelina Spring.-About 2 miles east of Stuart Spring, or 5 miles west of Yaqui Well, in Grapevine Canyon, there is reported to be a seep of water in the canyon gravel. At times the water flows at the surface and at other times one must dig for it. It is a few hundred feet from the road and was not noticed in traversing the canyon road. Stuart Spring is a much more valuable watering place for travelers. (See PI. VI.)

Anshutz Well.- In canyon in Eagle Mountains about 3 miles from MeccaBlythe highway. (See Pl. VI.) Inaccessible except on foot. Consists of trench and tributary tunnel. Small yield of good water.

Arrowweed Spring.-Dec. 28, T. 11 S.; R. 21 E. (See PI. VII.) Details lacking. Aztec Well.-Page 49; Plate VII.

Banner.-Pages 39-43; Plate VI.

Banner Creek.-Pages 39-43; Plate VI.

Banning.-Pages 15, 71.

Barrel Spring.-Pages 33, 36; Plate VI.

Big Morongo Creek.-Page 73.

Blythe.-Pages 47, 52, 58, 61, 63, 65 ; Plate VII.

Blythe Junction.-Pages 64, 65; figure 1.

Borego Spring.-Pages 32, 37 ; Plate VI.

Boulder Well.-Page 50; Plate VII. 
Brawley.-Pages 20, 22, 26, 34, 35; Plate VI.

Brooklyn mine.-Page 68; figure 2.

Brown Well.-Pages 64, 65; Plate VII ; figure 1.

Burnt Palms spring.-A little-known water hole in the Mecca Hills, east of Shaver Canyon, probably in sec. 10, T. 7 S., R. 10 E. It can be reached on foot from Shaver Canyon by a burro trail. It can also be reached by a trail entering the first large canyon in the Mecca Hills east of Shaver Canyon. The spring is identified by two large palms. Salt grass and mesquite grow in patches. It is usually necessary to dig a foot or two into the moist soil to get water, which is salty and of poor quality. (See Pl. VI.)

Cabezon station.--Pages 15, 18, 71.

Calexico.-Large town in Imperial Valley. (See Pl. VII.)

Calipatria.-Pages 22, 23; Plate VI.

Campbell ranch.-In the west end of Vallecito Valley, in sec. 7, T. 14 S., R. 6 E., about a mile southwest of the direct road through Vallecito and Mason valleys. Good water for domestic use is obtained at a spring west of the ranch house. (See Pl. VI.)

Canebrakes.-Pages 40,42 ; Plate VI.

Canyon Spring.-In a deep tributary of the Salt Creek Wash at the south side of the Orocopia Mountains, probably in sec. 20, T. 7 S., R. 13 E. It is about 1 mile north of the old stage route between Dos Palmas and Chuckwalla Well. At this place there is also a county sign which gives directions to the spring and other places. The spring is accessible by a wagon road, leading off from the main road, probably not passable for automobiles. The supply of water is a small seep in the sand of the canyon, and is not of good quality. (See Pl. VI.)

Carrizo.-Pages 40, 42, 43, 45; Plate VI.

Chocolate Mountains water holes.-These appear on the map of a Land Office survey (1915) and are labeled "Water in Holes," with two holes, evidently natural tanks, shown on opposite sides of a small canyon draining north near the summit of the Chocolate Mountains. They are near the south quarter stake of sec. 10 , T. 11 S., R. $17 \mathrm{E}$. Some natural tanks are reported by local inhabitants to occur in this part of the range several miles east of Salvation Spring. These are probably the ones. (See Pl. VII.)

Chuckwalla Well.-Pages 51, 53; Plate VII.

Clark Well.-At north side of Clark Dry Lake, in a large inclosed basin at the south end of the Santa Rosa Mountains. Accessible by poor and infrequently traveled trails from Borego Valley or from the summits of the Santa Rosa Mountains, and can be reached by wagon probably only from Borego Spring or Valley. It was not visited during this investigation. Some reports stated that in 1918 the well was filled up and water not obtainable, but that ground water was obtainable at shallow depth by digging. The water is said to be good. (See Pl. VI.)

Clemens Well.-Pages 50, 54; Plate VI.

Coachella.-Pages 16, 18, 22 ; Plate VI.

Coffey Spring.- This spring is reported to be located at the south base of the Chocolate Mountains, 6 miles northeast of Frink Spring, in an arroyo leading toward the latter place. It is said that wagons can follow the arroyo to the spring. It is reported to furnish good water.

Corn Spring.-Page 49 ; Plate VII.

Cottonwood Spring.-Pages 68, 69 ; Plate VI.

County Well. - On road between Indio and Piñon Well. Page 70; Plate VI.

County Well (new).- On road between Holtville and Yuma. Pages 29, 31; Plate VII. 
County Well (old).-On road between Holtville and Yuma. Pageș 29, 30; Plate VII.

Covington ranch.-Page 73; figure 2.

Coyote Well.-Page 73; figure 2.

Coyote Wells.-Pages 27, 28; Plate VI.

Dale.-Pages 68,74 ; figure 2.

Desert Queen Well.-Page 75 ; figure 2.

Dixieland.-Pages 27, 28, 41; Plate VI.

Dos Cabezas.-A spring of good water reliably reported to exist at the north edge of the mountains about 12 miles west of Coyote Wells, from which it is accessible by a poor wagon road that leads on up Carrizo Gorge to Jacumba. The spring is somewhere in the south part of T. $16 \mathrm{~S}$., R. $8 \mathrm{E}$. It is said to have a rather large flow. (See Pl. VI.)

Dos Palmas.-Pages 50, 54; Plate V.

Durmid.-A station on the Southern Pacific Railroad east of Salton Sea. It is supplied with water hauled from Mecea by the railway company. (See Pl. VI.)

Eagle Tank.-A natural rock basin about 20 feet in diameter and 10 to 15 feet deep in the bed of a gorge tributary to Placer Canyon, in the northwestern part of the Eagle Mountains. The gorge is the third large one entering Placer Canyon from the south below the old Placer Canyon reservoir, at a distance of about half a mile, and the tank is several hundred yards from its mouth. It is at the base of a vertical cliff about 20 feet high in the gorge bottom. The tank is said to contain water all the year round, but during the dry season the water is stale and dirty. There are several other tanks in the Eagle Mountains which hold water for several weeks or a month after the rains. (See Pl. VI.)

Edom.-A station on the Southern Pacific Railroad about 12 miles northwest of Indio. It is accessible by poor wagon roads, and there is talk of building a good road into Indio. Some ranches are being developed in the vicinity, it is reported, and well water is obtainable, but at what depth is not known. Like all the railway stations in the desert it constitutes a possible watering place. (See Pl. VI.)

Ehrenberg Ferry.-Page 47 ; Plate VII.

El Centro.-Pages 26, 28, 31, 41; Plate VI.

Eldorado mine.-Pages 69, 71, 76; Plate VI; figure 2.

Figtree John Spring.-Pages 19, 21; Plate VI.

Fish Spring.-Pages 19, 21; Plate VI.

Flowing Well.-A station on the Southern Pacific Railroad, about 4 miles east of Niland. According to tradition there was once a seep of bitter water at a near-by spring but never a flowing well. Water is hauled from Mecca and a cistern maintained for the few inhabitants. The place is about half a mile from the main road between Niland and Yuma. (See Pl. VII.)

Ford Well.-Pages 47, 48; Plate VII.

Frey Well.-Pages 15, 18; Plate VI.

Frink Spring.-Page 55; Plate VI.

Garden of Eden.-Page 77 ; Plate VI.

Glamis.-Pages 23, 26, 59; Plate VII.

Graham Well.-Page 67 ; Plate VII.

Granite mine.-In the north edge of the Chuckwalla Mountains. Reached by a branch road that turns south from the Mecca-Blythe highway at a point 41.3 miles from Mecca. The well is on the east bank of a gully about 15 feet deep, cut through granite at the base of the mountains. From it 
a pipe line leads east to a mill, but this line was not in order when seen. Water had evidently been pumped by engine but could be obtained only by rope and bucket, and these were not provided. The well measured 41 feet deep, water being reached at 22.5 feet. Water drawn from the well appeared a little stale, as if from long standing, but looked clear and did not taste bad. It is probably excellent when regularly used. (See Pl. VII.)

Granite Tanks.-Reported as existing in the northeast corner of Chuckwalla Mountains, in a canyon near the mountain border, and said to be accessible by wagon. They are little used, except by prospectors, Granite mine and Corn Springs being more prominent watering places. The water supply is usually dependable but perhaps not always so. (See Pl. VII.)

Grapevine Spring.-Pages 32, 37; Plate VI.

Gray post office.-See Palm Springs station. Page 76 ; Plate VI ; figure 2.

Grays Well.-Now abandoned. Formerly furnished mill water for Gray's mill, a gold mill in the desert about 5 miles south of Blythe Junction. The well is in T. 2 S., R. 20 E., probably in sec. 11. Water is reported to have been obtained at a depth of 137 feet. It was too salty for domestic use. (See fig. 1.)

Gruendike Well.-Pages 46, 48; Plate VII.

Gulliday Well.-Pages 51, 57 ; Plate VII.

Gyp Well.-Pages 64, 65 ; Plate VII.

Hanna Well.-At north edge of Fish Mountain, in a canyon known as Fish Creek, through which runs a very poor wagon road connecting Carrizo and San Felipe valleys. It is easily accessible from the north, however. Conflicting reports state that water is unobtainable and that there is plenty of good water. The well is in sec. 29 , T. 13 S., R. $9 \mathrm{E}$., and has been used to supply prospecting and well-drilling parties. (See Pl. VI.)

Harper Well.-Pages 34, 35; Plate VI.

Hayfields.-Pipe line crossing road at the Hayfields and carrying water from spring in Eagle Mountains. Pages 46, 48; Plate VI.

Heber.-A small town in Imperial Valley, on the railway between El Centro and Calexico. There are several stores and houses and provisions, automobile supplies, and water are obtainable. (See Pl. VI.)

Hedges.-See Tumco.

Henson Well.-In the NW. $\frac{1}{4}$ sec. 26 , T. 3 S., R. 8 E., about three-quarters of a mile south of the road from Piñon Well to Indio, 1.3 miles from Piñon Well. Accessible by a burro trail, possibly even by wagon. The well is in a little flat in a very narrow canyon and is high up near the summit of the Little San Bernardino Mountains. It is a dug hole about 4 feet square and reaches water at about 10 feet. It is curbed with boards and was provided with a rope and bucket but needed cleaning in January, 1918. The water was at that time siphoned to Eldorado mine with that of Piñon Well. (See Pl. VI.)

Heyburn Well.-Indicated on a township plat of the General Land Office (1915 survey) as being near the south quarter stake of sec. 13, T. 11 S., R. $16 \mathrm{E}$. It is at the south base of the Chocolate Mountains, in the mouth of a large arroyo, and there is a cabin near it. A wagon trail leading to the NilandYuma road is shown. Nothing more is known of it. The entrance to the canyon is prominent reentrant in the Chocolate Range just east of Salvation Pass. (See Pl. VII.)

Hidden Spring.- An excellent but very little known water hole in the eastern part of the Mecca Hills, probably in sec. 11, T. 7 S., R. $10 \mathrm{E}$. It can be reached on foot by following the burro trail to Burnt Palms (see p. 78), going down Burnt Palms Wash to its junction with a larger canyon from 
the east, and following this larger canyon for a mile to the east. This was the route used by the writer. Automobile tracks leading up the canyon, however, indicate that it is accessible by vehicles from the southwest. (See Pl. VI.)

Hole-in-the-Wall Spring.-Page 73 ; figure 2.

Holtville.-Pages 28, 31; Plate VII.

Hopkins Well.-Pages 47, 48; Plate VII.

Imperial.-Pages 26, 27, 44; Plate VI.

Indian Wells.-Pages 16, 17; Plate VI.

Indio.-Pages 16, 17 ; Plate VI.

Iron Ohief mine.-Page 69 ; Plate VI.

Jacumba.-Pages 27, 28; Plate VI.

Julian.-Pages 38, 43 ; Plate VI.

Kane Spring.-Pages 19, 34, 35; Plate VI.

Keys ranch.-Page 75 ; figure 2.

Laguna (Laguna Mountains).-The Laguna is a small lake at a high elevation near the crest of the Peninsular Range, in T. 15 S., R. 5 E. Little is known about it. Other small lakes are reported in the vicinity. (See Pl. VI.)

Laguna Dam.-Page 63; Plate VII.

Laguna Mountain Spring.-The following description of a nameless spring in the Laguna Mountains is taken from field notes accompanying Withdrawal No. 331, Public Water Reserve No. 14, California No. 2. "The spring is in the NW. $\frac{1}{4}$ NW. $\frac{1}{4}$ sec. 24 , T. 15 S., R. 6 E. It is located near the head of a deep canyon of northeasterly trend (evidently Canebrake Canyon). The water seeps from the ground under a large granite boulder, flows for 100 feet, and sinks in sand. The flow is about 5 gallons a minute. The spring is 6 miles from a wagon road (probably the Julian-El Centro road) and 3 miles from water (Canebrake Canyon). The surrounding rocks are gray granite." (See Pl. VI.)

Lost Horse Well.-Also known as Lost Horse Spring. In the NE. $\frac{1}{4}$ sec. 21, T. 2 S., R. 8 E. Reached by a branch road that turns south 2.8 miles east of Quail Spring at a fork marked by a Geological Survey sizn, from which it is 5.5 miles distant. It is also accessible by a dim road leading south 1.1 miles southeast of the Geological Survey sign at Keys ranch, from which it is about 3 miles distant. It is in the east edge of a high valley on the northeast side of the Little San Bernardino Mountains, at the foot of a long granite spur a few hundred feet high which forms the east wall of the valley. The position of the well is marked by two great patches of very white granite surrounded by much darker rock on the mountain side just east of the well. The well is 39 feet deep. In 1918 this well and another in the same vicinity were in poor condition. (See PI. VI.)

Magnesia Spring.-A small spring of poor water in Magnesia Canyon, in sec. 14, T. 5 S., R. 5 E. It can be reached by wagon from the Banning-Brawley road but is almost never used as a watering place. It may be of some importance to prospectors. (See Pl. VI.)

Maria Mountains Tank.-A large tank is reported by several persons to exist near the center of the Maria Mountains, in a big canyon draining west. It is said to be approachable within a short distance by wagons on the west and to be connected with Willow Spring, 3 miles east, by a burro trail. It holds water most of the year.

McCain Spring.-Pages 19, 21; Plate VI.

McCoy Spring.-Pages 49, 67 ; Plate VII.

McCoy Tanks.-Page 67; Plate VII. 
Mecca.-Pages 16, 20, 22, 45, 49, 50, 55, 68; Plate VI.

Mill Camp.-Page 49; Plate VII.

Mineral Switch.-Page 66; Plate VII.

Mohave Tank.-In T. 3 S., R. 20 E., probably in or near sec. 28. It is in a canyon in the north edge of the Little Maria Mountains and is accessible from the Blythe-Blythe Junction road. It can be reached by going southwest from Gyp Well on a plain road. Turn to the right about half a mile from the well and follow a dim wagon trail, continuing southwest toward a gap very plainly visible in the mountains. At about $3 \frac{1}{2}$ miles from Gyp. Well the road ends beside a deep gully in the edge of the mountains. A burro trail goes on across the pass to Chandler Well. The Mohave Tank is in the bed of the gully about 100 yards south of the end of the wagon road. The tank occupies a hole formed by flood waters pouring over a cliff about 15 feet high in the canyon bed. When visited in October, 1917, a pool of water 12 to 15 feet in diameter and 2 to 3 feet deep stood in the little basin. A large amount of sand and gravel filled the bottom of the hole, so the actual water content was probably considerably greater than it appeared on the surface. Natives say that it has never been known to be entirely dry. The tank is a favorite watering place for the mountain sheep. and other wild animals, of which signs are plentiful. Its remoteness from roads and settlements, however, causes it to be of small importance to people generally. (See Pl. VI.)

Morongo Creek.-Page 73.

Mortmar.-A station on the Southern Pacific Railroad, about 8 miles southeast of Mecca and 1 mile off the road to Dos Palmas. Water is hauled from Mecea, but there are flowing wells in the neighborhood. It constitutes a possible watering place, but is off the usual lines of travel. Name recently changed from Mortmere. (See Pl. VI.)

Mountain Palms Spring.-Pages 40, 42 ; Plate VI.

Mountain Springs.-Pages 27,.28; Plate VI.

New County Well.-On road between' Holtville and Yuma. Pages 29, 31 ; Plate VII.

Niland.-Fages 22, 23, 26; Plates VI and VII.

Oasis School.-Pages 19, 21; Plate VI.

Ogilby.-Pages 24, 25; Plate VII.

Old County Well.-On road between Holtville and Yuma. Pages 29, 30 ; Plate VII.

Old Virginia Dale.-Same as Old Dale. Pages 68,74 ; figure 2.

Packard Well.-Pages 50, 67; Plate VII.

Packer Well.-See Packard Well. Pages 50, 67; Plate VII.

Palen Well (dry).-Page 50; Plate VII.

Palm Canyon.-Page 77 ; Plate VI.

Palm Spring, San Diego County.-Not to be confused with Palm Springs village, in Riverside County. It is not associated with palm trees, although some are said to have grown there years ago. It is in sec. 25, T. 14 S., R. 7 E., about half a mile north of a trail leading down the dry bed of Vallecito. Creek from Vallecito to Carrizo. It can be reached by turning aside. There are mesquite trees at the place. A small seep of water issues from the base of some clay hills. It is said to be necessary sometimes to dig for water. The place was not visited during this investigation. (See: Pl. VI.)

Palm Springs, Riverside County.-Page 15; Plate VI.

Palm Springs station.-Page 76; Plate VI ; figure 2. 
Palm Wash.-In secs. 21 and 22, T. 10 S., R. 9 E., are several little seeps of water marked by a few palm trees. They can be reached by following an arroyo west from the Coachella-Brawley road, but the place is hard to find. The arroyo is crossed $8 \frac{1}{2}$ miles south of Fish Spring, and the springs are about 3 miles away. The water is bitter and undrinkable. Drinkable water is said to have been found at places in the arroyo by digging pits and using the water continuously. (See Pl. VI.)

Palo Verde.--Pages 58, 60, 63; Plate VII.

Patterson Well.-Page 47; Plate VII.

Peg Leg Well.-Page 58; Plate VII.

Picacho.-Page 63; Plate VII.

Pinkham Well.-Sometwhere in an arroyo draining north out of the Cottonwood Mountains, about 7 miles from Cottonwood Spring, is a water hole called Pinkham Well, developed by C. A. Pinkham, of Mecca. It can be reached by a poor wagon road from Cottonwood Spring. The supply is said to be reliable, and the well is used by prospectors. (See Pl. VI.)

Pinyon Well.-Pages 70, 75; Plate VI; figure 2.

Potholes.-Page 63; Plate VII.

Priest Well.-In T. 2 S., R. 20 E., probably in sec. 8. Reached by a branch road that turns west from the Blythe-Blythe Junction road, 3.7 miles from Blythe Junction. It is in the Blythe Junction Basin, about 2 miles north of Brown Well and about a mile from the base of Arica Mountain. The well was drilled in the summer of 1917 by a mining man named Priest, after whom it is named. In October, 1917, there was a pumping plant at the well which delivered water to the Assets Realizing Mining Co.'s gold mine, 2 miles west, in the summit of Arica Mountain. Mr. Cox, superintendent of the mine and pumping plant, reported the depth of the well as , 587 feet and the depth to water as 507 feet. The water is rather salty and is not used for domestic purposes. It comes from the well at a temperature of $90^{\circ}$. (See fig. 1.)

Quail Spring.-Page 75; figure 2.

Rannells.-Pages 52, 53, 58, 60, 63 ; Plate VII.

Red Butte Spring.-A little-known spring is reliably reported to exist in the north end of the Palo Verde Mountains, near a prominent peak called Red Butte, from which the name is taken. It is in T. 9 S., R. 20 E., probably in sec. 9 or 10 . No roads lead to the spring, and it is reached only by burro trails. The location is given as one-fourth mile northeast of the base of Red Butte, in a little canyon coming from that mountain. The place should be easily found, as Red Butte, which is really not a butte but a sharp-pointed round peak, evidently a volcanic neck, is an unmistakable landmark. When viewed from the north or east it appears as an isolated red peak at the north end of the Palo Verde Mountains and not far from the Flat Top Mountains, two broad table-like summits easily distinguished in the west end of the Palo Verde Mountains. The water is said to seep out of rock in the canyon. The flow is small but unfailing. The name Clapp Spring has also been used for it but does not seem to be very widely accepted. (See Pl. VII.)

Red Cloud mine.-Page 49; Plate VII.

Rice.-New name for Blythe Junction. (See p. 63.)

Salton.-A station on the Southern Pacific Railroad, at the northeast corner of Salton Sea. The place was once the center of salt-mining activity in Salton Basin, but the fiooding of the basin has ended the industry, and the place is now relatively unimportant. It is accessible by a road from Dos Palmas or by a wagon road along the railway. Both are bad, and the place is not

$157138^{\circ}-20-7$ 
often visited. Water is hauled from Mecca by rail, and travelers can get water there if necessary. (See Pl. VI.)

Salvation Spring.-Page 58; Plate VII.

San Felipe.-Pages 33, 36; Plate VI.

San Felipe Creek.-Where crossed by the Coachella-Brawley road about a mile north of Kane Spring San Felipe Creek usually has a considerable surface flow, perhaps 1 second-foot. The water is exceedingly bitter, and analysis indicates that it is unfit for any human use. Care should be taken not to drink it or give it to animals. (See Pl. VI.)

San Felipe ranch.-The San Felipe ranch house is in sec. 24, T. 12 S., R. 4 E. It is in the center of a large land grant known as the San Felipe ranch which includes the larger part of the good land in upper San Felipe Valley. The ranch house is about 15 miles from Warner and is accessible by fair mountain roads either from that place or from Julian. Several wells near the house supply good water for domestic use and for irrigation. Some of them yield a small flow. Watering places are rather abundant in the neighborhood, and travelers probably water most frequently, at Banner Creek or The Windmill, which are more public places a few miles away. At the Wilson ranch, about 5 miles north, water is also convenient to the road. (See Pl. VI.)

San Felipe Valley windmill.--Page 39; Plate VI.

Seeley.-Page 28; Plate VI.

Seven PaIms.-An artesian spring about 3 miles east of Palm Springs station, in sec. 18 , T. 3 S., R. 5 E. It is on a poor wagon road leading from Palm Springs station to Edom and is seldom frequented by travelers. There is a pool of water several feet in diameter directly by the roadside at the base of a large cluster of wild palm trees. There is a dense mat of arrowweed, cane, and mesquite about the pool. The water appears to be of good quality. The supply is probably several gallons a minute. (See Pl. VI.)

Seventeen Palms.-Accessible by very bad road from Borego Spring to Coachella-Brawley road. Seep of bitter water in clay hills. Pages 19, 31; Plate VI.

Shaver Well.-Pages 46, 49, 68; Plate VI.

Smith Well.-Pages 59, 60, 63; Plate VII.

Smuggler Spring.-Pages 27, 28; Plate VI.

Soda Springs.- In sec. 36, T. 10 S., R. 9 E., about $2 \frac{1}{2}$ miles north of McCain Spring and the same distance west of the Coachella-Brawley road. They are in a wash leading up to Sevienteen Palms and probably accessible if the right arroyo can be found on leaving the main road. The springs are at the base of a prominent hill called Clay Point, which is just above the old beach. The water is very bitter, almost undrinkable. They were not visited. (See Pl. VI.)

Stirrup Tank.-Two and one-half miles south and a little west of White Tanks, in the north edge of the Hexie Mountains, is a natural rock tank said to contain water at times. It is in an inaccessible locality and is of importance only to prospectors.

Stuart Spring.-Pages 32, 37; Plate VI.

Stubby Spring.-In the SE. 1 sec. 27, T. 2 S., R. 7 E., near the summit of the Little San Bernardino Mountains. A wagon road, said not to be very good, leads east to the Lost Horse Well, about 7 miles away, and a trail once led south to Indio past a place called the Thousand Palms Canyon but is now impassable. The spring is said to yield about a miner's inch of good water and is always reliable:

Sumac Spring.-Same as Stuart Spring. Pages 32, 37; Plate VI. 
Sunset Spring.-In sec. 7, T. 14 S., R. 16 E., in the east side of Imperial Valley. It is a seep of water from moist alkaline soil and is due to the escape of imperfectly confined artesian water in the Holtville area. The spring is now in the center of a field and is important only historically and as an indication of ground-water conditions. It was once a useful watering place, but its location is at present almost unknown even to local residents. (See P1. VII.)

Tabaseca Tank.-Natural tank in deep arroyo. Water often concealed by gravel filling. Pages 51, 54; Plate VI.

Talmadge Well.-A flowing well owned by W. S. Talmadge in sec. 8, T. 3 S., R. 5 E., in upper Coachella Valley. It is about half a mile northeast

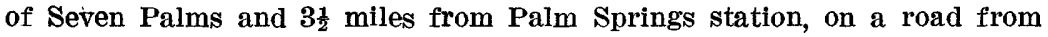
that station to Edom. This road is bad and seldom traveled. The flow is about 15 gallons a minute. Analysis shows a rather high mineral content, particularly of sulphate, but the water tastes good and is freely used for drinking. (See Pl. VI.)

Thermal.-Pages 16, 17, 18, 22 ; Plate VI.

The Windmill.-In San Felipe Valley. Page 39; Plate VI.

Thousand Palms Canyon.-A celebrated but difficultly accessible water hole in the northeast corner of T. 4 S., R. 6 E. A survey made by the Southern Pacific Co. for a gravity water supply for Indio indicates an estimate of several hundred gallons a minute available h/ere. The canyon can be reached by a poor wagon trail from Indio, but the exact route is unknown. The trail once led on to Stubby Spring. There is a remarkably large grove of palms in the canyon. (See Pl. VI.)

Tolbard Well.-In the western part of T. 11 S., R. 21 E., are a group of manganese claims which were developed in a commercial way in 1918, owing to the demand for manganese created by the war. Owners of one property, called the Tolbard mine, are reliably reported to have made a well about 2 miles south of the mine in a large arroyo leading northèast and obtained good water for use at this mining camp. (See Pl. VII.)

Toro Springs.- On the western border of the southern part of Coachella Valley. Were once important desert watering places but are now off the main lines of travel and are important chiefly to the Indians of the surrounding reservation. The springs are in sec. 1, T. $7 \mathrm{~S} ., \mathbf{R} .7 \mathrm{E}$. They are accessible by various roads of the network now existing in Coachella Valley. (See Pl. VI.)

Tumco.-Formerly known as Hedges. It is an abandoned mining camp in the west edge of the Cargo Muchacho Range, about 4 miles north of Ogilby. It is very near the Tumco branch of the Blythe-Yuma road. In 1918 the place was a "ghost city" of empty houses, and no water was obtainable. When it was prosperous water was pumped from Colorado River. It may become a watering place again should mining activities revive. (See Pl. VII.)

Twenty-nine Palms.-Page 74; figure 2.

Vallecito.-Pages 40, 42; Plate VI.

Warner.-Pages 31, 38; Plate VI.

Warren ranch (also called Covington ranch).-Page 73 ; figure 2.

Warren Tank.-Page 73; figure 2.

Warren Well.-Page 73 ; figure 2.

Westmoreland.-Pages 20, 34, 35 ; Plate VI.

White Tank.-Page 71; Plate VI; figure 2.

Whitewater River.-Pages 15, 18; Plate VI.

Whitewater station.-Pages 15, 18; Plate VI. 
Wiley Well.-Pages 49, 52, 53 ; Plate VII.

Willow Holes.-Should not be confused with Willow Spring, in the Maria Mountains. It is a spring in sec. 21, T. 3 S., R. 5 E., and originates in a cienaga in the Indio Hills, very similar to the Thousand Palms Canyon, according to report. There is a small stream of good water the year around, which rises in a wash or canyon passing through the hills. The place is accessible by a poor wagon road from Palm Springs station or from Edom. (See Pl. VI.)

Willow Spring.--Reliable spring in a canyon on east side of Maria Mountains. Trails to Blythe Intake and Maria Mountains tank. Page 66; Plate VII.

Wilson ranch.-See San Felipe ranch.

Windmill, San Felipe Valley-Page 39 ; Plate VI.

Winterhaven.-Pages 24, 25, 29, 30 ; Plate VII.

Wister.-A railway station about 7 miles by rail northwest of Niland, on the Southern Pacific line. Water is hauled by rail from Mecca and stored in a cistern. Travelers may get water if necessary. The place is accessible by fairly good roads from Niland. (See Pl. VI.)

Yaqui Well.-Pages 32, 37 ; Plate VI.

Yuha.-Variously known as Yuha Spring or Yuha Well, is at present neither a spring nor a well but is a locality having very shallow water in secs. 4, 5 , 8, and 9, T. 17 S., R. 11 E. It can be reached by a very poor road branching from the San Diego highway near Dixieland, and automobiles will find the last mile very difficult, as there is practically no road at all. Water is very shallow in several places in the bed of an arroyo. The location of water can generally be determined by patches of salt grass, and the water is obtained by digging a foot or two. It is very bitter. The well, which was once an important water hole in this portion of the desert, has been destroyed, and there is practically no travel whatever to the place at present. Considerable water could be obtained by shallow -wells at properly selected spots, but it would be very poor, although probably drinkable. (See Pl. VI.)

Yuma.-Pages 24, 25, 30, 62; Plate VII.

Yuma Dam.-See Laguna Dam. Page 63 ; Plate VII.

Zacaton Spring. $\rightarrow$ Shown on the U. S. Geological Survey reconnaissance topographic map of Salton Sink as in sec. 8, T. 11 S., R. 9 E., about halfway between Soda Springs and Seventeen Palms, in the same arroyo. Nothing more is known of it. It is probably a seep of bitter water from clay hills or in the bed of an arroyo. (See Pl. VI.)

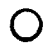

